\title{
Arrival Condition of Spent Fuel After Storage, Handling, and Transportation
}

November 1982

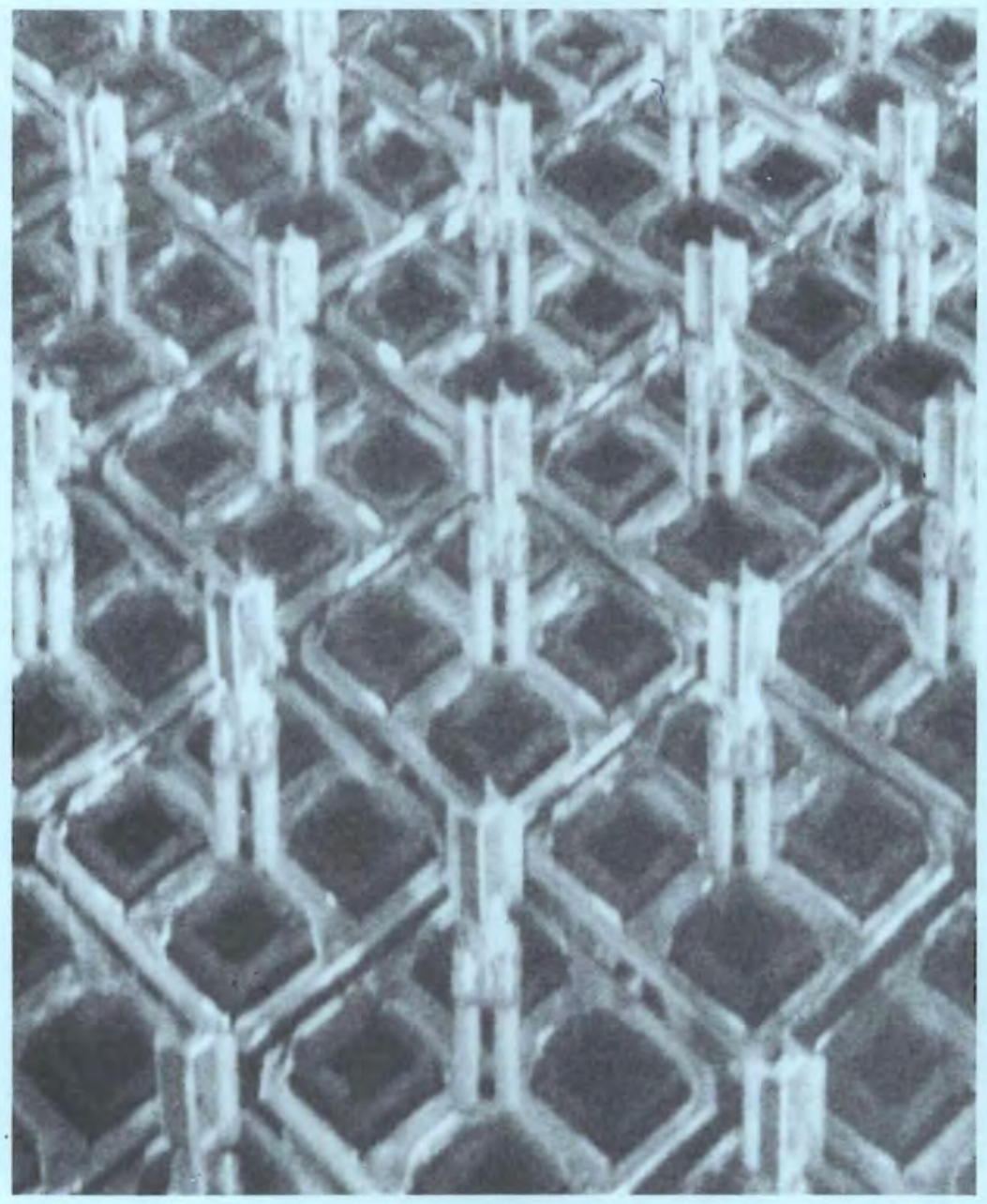

Prepared for the Commercial Spent Fuel Program Office and the Sandia National Laboratories Transportation Technology Center for the U.S. Department of Energy under Contract DE-AC06-76RLO 1830

Pacific Northwest Laboratory

Operated for the U.S. Department of Energy

by Battelle Memorial Institute 


\title{
DISCLAIMER
}

This report was prepared as an account of work sponsored by an agency of the United States Government. Neither the United States Government nor any agency thereof, nor any of their employees, makes any warranty, express or implied, or assumes any legal liability or responsibility for the accuracy, completeness, or usefulness of any information, apparatus, product, or process disclosed, or represents that its use would not infringe privately owned rights. Reference herein to any specific commercial product, process, or service by trade name, trademark, manufacturer, or otherwise, does not necessarily constitute or imply its endorsement, recommendation, or favoring by the United States Government or any agency thereof. The views and opinions of authors expressed herein do not necessarily state or reflect those of the United States Government or any agency thereof.

\author{
PACIFIC NORTHWEST LABORATORY \\ operated by \\ BATTELLE \\ for the \\ UNITED STATES DEPARTMENT OF ENERGY \\ under Contract DE-AC06-76RLO 1830
}

Printed in the United States of America
Available from
National Technical Information Service
United States Department of Commerce
5285 Port Royal Road
Springfield, Virginia 22151
NTIS Price Codes
Microfiche A01
Printed Copy
Pages
$001-025$
$026-050$
$051-075$
$076-100$
$101-125$
$126-150$


ARRIVAL CONDITION OF SPENT

FUEL AFTER STORAGE, HANDLING, AND TRANSPORTATION
W. J. Bailey
P. J. Pankaskie
D. C. Langstaff(a)
E. R. Gilbert
K. H. Rising
R. E. Schreiber

November 1982

Prepared for the Commercial Spent

Fuel Program Office and the

Sandia National Laboratories

Transportation Technology Center for

the U.S. Department of Energy

under Contract DE-ACO6-76RLO 1830

Pacific Northwest Laboratory

Richland, Washington 99352

(a) On subcontract to Pacific Northwest Laboratory from Columbia Engineers Services, Inc., TAD Technical Services Corp., Los Angeles, CA 90045 , to provide technical assistance on this project. 


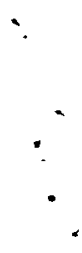




\section{ABSTRACT}

This report presents the results of a study conducted by Pacific Northwest Laboratory (PNL) to determine the probable arrival condition of spent lightwater reactor (LWR) fuel after handling and interim storage in spent fuel storage pools $(a)$ and subsequent handling and accident-free transport operations under normal or slightly abnormal conditions. The objective of this study was to provide information on the expected condition of spent LWR fuel upon arrival at interim storage or fuel reprocessing facilities or at disposal facilities if the fuel is declared a waste. Results of a literature survey and data evaluation effort are discussed. Preliminary threshold limits(b) for storing, handling, and transporting unconsolidated spent LWR fuel are presented. The difficulty in trying to anticipate the amount of corrosion products (crud) that may be on spent fuel in future shipments is also discussed, and potential areas for future work are listed.

(a) Of the fuel bundles currently in storage, about $93 \%$ are in pools at reactor sites and about $7 \%$ are at independent pool facilities.

(b) Those conditions at which fuel bundle degradation and failure mechanisms are expected to begin to be activated, especially those mechanisms that may cause the loss of fuel rod cladding containment integrity for both free volatile and/or nonvolatile solid radionuclides. 
.

•

,

' 


\section{SUMMARY}

It is important to know the condition of spent light-water reactor (LWR) fuel after storage and handling at spent fuel storage pools at reactor sites and at independent facilities and after handling and transport to other interim storage sites or fuel reprocessing plants. In addition, if spent fuel is declared a waste, its expected arrival condition at a repository must be adequately defined to support spent fuel repository and packaging facility design and operations. The U.S. Department of Energy (DOE) has need for spent fuel characterization information under normal or slightly abnormal (i.e., "accident-free") conditions. As a result, a study was conducted to determine the probable arrival condition of spent LWR fuels after storage in water (wet storage) and subsequent handling and transport. The study was initiated at Pacific Northwest Laboratory (PNL) in fiscal year (FY) 1980 for DOE's Transportation Technology Center at Sandia National Laboratories, but the third and final phase of study was not funded in FY 1982 because of budget cuts and reorientation of $D O E$ programs. Because the information was useful to DOE'S Commercial Spent Fuel Management (CSFM) Program at PNL, the unpublished results of the two completed phases were combined to form this report for the CSFM Program. This report describes the findings of the spent fuel literature survey and data evaluation (including a compilation of cases of known or suspected damage to unconsolidated LWR fuel ${ }^{(a)}$ as a result of wet storage, handling, and transporting operations under slightly abnormal or abnorma 7 conditions); describes preliminary conclusions on threshold limits $(b)$ for storing, handling, and transporting spent LWR fuel bundles; discusses the difficult

(a) In current planning for future fuel storage, one option being seriously considered is rod consolidation, which involves the storing of close-packed arrays of fuel rods in containers rather than the storing of fuel bundles.

(b) Those conditions at which fuel bundle degradation and failure mechanisms are expected to begin to be activated, especially those mechanisms that may cause the loss of fuel rod cladding containment integrity for both free volatile and/or nonvolatile solid radionuclides. 
problem of trying to make projections about the amount of corrosion products (crud) $^{(a)}$ that may be present on spent fuel in future shipments; and lists potential areas for future work.

At the end of 1981, there were nearly 30,000 spent LWR fuel bundles being stored in water at reactor spent fuel pools and at independent spent fuel storage installations in the United States. (1) of those, about two-thirds are from domestic boiling water reactors (BWRs) and about one-third are from domestic pressurized water reactors (PWRs). About 95\% of these fuel bundles contain fuel rods with Zircaloy cladding; about $5 \%$ contain fuel rods with stainless steel cladding. Normal handling/transporting operations have involved tens of thousands of fuel moves. Although some slightly abnormal and abnormal events have occurred, it is concluded in this study that very few fuel bundles have sustained major mechanical damage due to handling operations. In most cases involving handling damage, minor degradation of fuel bundle components resulted with no breaching of the fuel rod cladding or release of radioactive gases or solids.

The PNL study included an evaluation of 89 cases $(72$ domestic and 17 foreign) in which damage to fuel occurred or may have occurred during handiing and/or transporting operations. Irradiated fuel was involved in all but 5 of the 89 cases. Of those cases where damage occurred during fuel handling, 2 were associated with receiving of fuel at the reactor; 54 , with fuel moves at reactor cores; 15, with fuel handling and cask loading at spent fuel pools; 1, with an interim fuel storage facility; 3 , with foreign reprocessing plants; and 1 , with a hot cell facility. In three cases, fuel was found or suspected to have been damaged during transport: one case involved fresh fuel shipments to a reactor, and two cases involved shipments of irradiated fuel from reactors.

(a) The generic term "crud" pertains to the particulate carried by the coolant in the primary coolant system and to deposits on the surfaces of fuel bundles, piping, heat exchanger shells, tubing, etc. The difference between these deposits and the corrosion layer intrinsic to a given structural material is that crud results primarily from mass transfer processes operating on the corrosion/erosion products from the various structural materials in contact with the primary coolant circuit. 
Over $80 \mathrm{Mg}$ of spent fuel bundles have been disassembled. (a) Very few fuel rods have been broken during disassembly operations.

If damage has occurred to fuel during shipment, it is apparently minor; however, little is known on the subject. In the reports on incidents involving fuel shipments ( see Appendix), the main emphasis has been on describing any release of radioactivity to the environment and damage to the cask. In most instances, no comment was made on the condition of the fuel as a result of the incident.

The amount and type of corrosion products (crud) on spent LWR fuel can have a very significant influence on the risk of transporting and handling operations with such fuel. This is because of the potential, in the event of an abnormal occurrence, for the radioactivity associated with the crud to enter man's environment. It is difficult to predict how much crud will be on spent fuel when it has been transported from a reactor. Even in nuclear power plants of similar design, the crud deposition on fuel rods is highly variable. Changes in crud characteristics depend on the chemical makeup of the crud and the nature of the crud environment. (b) These changes are difficult to predict accurately unless the initial crud characteristics and the effects of storage and transport environments are known. Currently, reactor water chemistry is the primary control used by industry to minimize crud production. Cleaning of spent fuel to reduce the amount of crud before fuel shipments may also decrease potential radiological hazards associated with handling, transporting, and storing spent fuel.

Potential degradation mechanisms for Zircaloy- and stainless steel-clad LWR fuel during extended water storage have been studied. There appears to be a sound basis for storing spent LWR fuel for several decades in water pools.

(a) An older BWR fuel assembly contains 49 fuel rods; a newer assembly contains 60 to 63 fuel rods. A BWR fuel assembly weighs about 290 to $320 \mathrm{~kg}$. A PWR assembly typically contains 176 to 264 fuel rods and weighs about 580 to $700 \mathrm{~kg}$.

(b) For example, the adherence of crud on spent LWR fuel bundles can be increased or decreased by drying, changing the oxygen concentration in the storage pool water, or vibration during transporting operations. 
A method of indexing the level of degradation for each spent fuel rod or array of spent fuel rods should be established. To assume that all fuel rods have a low level of degradation may lead to failure of specific fuel rods that have a high level of degradation during handling or shipment.

Evolutionary fuel designs (e.g., prepressurization) and/or potential changes in the normal duty cycle (e.g., extended burnup or load/demand following operation) are not represented to any significant extent in current interim pool storage experience.

One part of this study involves an investigation of threshold limits (a) for storing, handling, and transporting spent LWR fuel bundles. The use of threshold limits (e.g., for temperature, load/trip limits, and acceleration) would aid in maintaining the integrity of spent fuel rods, especially the integrity of the fuel and the cladding.

The main safety concern associated with the loss of cladding integrity is expected to be the release of some of the "free volatile" radionuclides from that fuel rod. The potential for impairment of cladding integrity during handling and transport appears to be the greatest for those fuel rods that sustained some damage short of cladding failure during prior duty, intermediate (in general) for sound spent fuel rods, and minimal (if temperatures are controlled) for already-failed rods. (b) At present, it is difficult to analyze fuel rods that have already sustained some damage. Current engineering practice, even as required for code applications (ASME, ANSI, etc.), pays little or no attention to the mechanics of response of already-degraded component materials and/or already-damaged assemblies or structures. There is currently a limited use of cumulative damage concepts for assessing the potential of failure from a succession of specific and anticipated loadings such as fatigue followed by and/or interspersed with creep. Until recently, there were no

(a) Those conditions at which fuel bundle degradation and failure mechanisms are expected to begin to be activated, especially those mechanisms that may cause the loss of fuel rod cladding containment integrity for both free volatile and/or nonvolatile solid radionuclides.

(b) Irradiated fuel bundles with known failed fuel rods may be canned prior to shipment. 
cumulative damage functions for combining the effects of more than a single loading mode. The strain energy absorption to failure (SEAF) concept appears to offer considerable potential as a cumulative damage rule and a failure criterion. Of the currently available cumulative damage rules, SEAF alone appears to offer an approach for cumulative damage considerations that include environmental effects in addition to temperature and creep, fatigue, thermal, mechanical, and/or impact loading modes. However, considerable experimental research would be needed to fully develop the strain rate-dependent and environmentdependent SEAF concept as a cumulative damage rule and a failure criterion.

Temperature limits for storage conditions for spent fuel rods with unbreached and breached cladding are suggested. The use of such limits would substantially reduce the likelihood of spent fuel degradation and failure, which could result in emission and dispersal of radionuclides.

Preliminary limits for interim storage, handling, and normal transport (a) to terminal storage (or reprocessing) facilities are suggested as follows:

- interim storage in water

a) fuel-to-cladding interface temperatures of $\leq 620 \mathrm{~K}\left(350^{\circ} \mathrm{C}\right)$ for nonfailed fuel rods

b) exposed fuel surface temperature of $\leq 570 \mathrm{~K}\left(300^{\circ} \mathrm{C}\right)$ for failed fuel rods

- handling - current load/trip limits in force at the reactor and at interim storage pool facilities; it is presumed that the load/trip setting at all LWR facilities (for example, for cranes and other handling equipment) is 1.5 times the fuel bundle weight

- nomal transport

a) fuel-to-cladding interface temperatures of $\leq 620 \mathrm{~K}\left(350^{\circ} \mathrm{C}\right)$ for nonfailed fuel rods

b) exposed fuel surface temperatures of $\leq 670 \mathrm{~K}\left(400^{\circ} \mathrm{C}\right)$ for failed fuel rods.

(a) Higher limits would be allowed for transport accidents. 
For dry storage of spent fuel rods with unbreached Zircaloy cladding, the highest permissible cladding temperature from this study is proposed to be $650 \mathrm{~K}\left(380^{\circ} \mathrm{C}\right)$ in helium or air. The cladding temperature limit for spent fue 1 rods with unbreached Zircaloy cladding in dry storage could be increased to perhaps $770 \mathrm{~K}\left(500^{\circ} \mathrm{C}\right)$ if the fuel rods were vented and subsequently resealed prior to storage in helium. Lower temperatures and an inert gas cover would be required for dry storage of spent fuel rods with breached cladding. The proposed temperature limit of $470 \mathrm{~K}\left(200^{\circ} \mathrm{C}\right)$ associated with $\mathrm{UO}_{2}$ oxidation in breached fuel rods in air is the lowest and limiting value.

For spent fuel, the acceleration limits for shock are tentatively estimated to be approximately $30 \mathrm{~m} / \mathrm{s}^{2}$ (three times the gravitational constant) for lateral loading ${ }^{(2)}$ and approximately $70 \mathrm{~m} / \mathrm{s}^{2}$ (seven times the gravitational constant) for axial loading. Spent fuel rods that are to be transported should be instrumented with accelerometers to document the maximum shock loadings. Fuel bundles or fuel rods that show excessively high shock levels should subsequently be inspected for damage and serious degradation.

Fatigue is not expected to be a significant problem with spent fuel due to the low number of load cycles that the fuel rods are expected to encounter.

Areas for future work in characterizing spent fuel conditions are also described, including a list of areas where supplemental data would be useful, a list of experiments of possible interest, and recommended areas for studies on crud. One particularly important area where data are lacking-detection of incipiently failed rods (a) - is of concern because these rods represent the most likely safety concern in handling and transport operations.

(a) The detection of failed fuel rods is a reasonably established procedure, but the detection of incipiently failed fuel rods is not.(3-5) 


\section{CONTENTS}

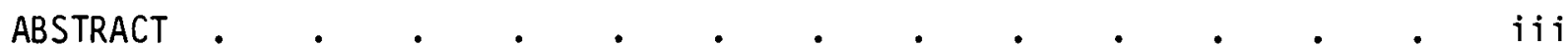

SUMMARY

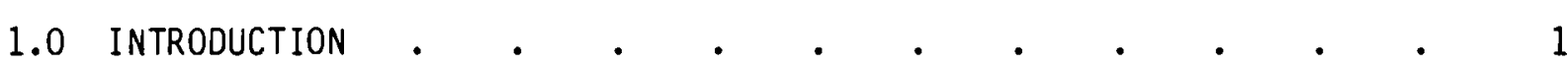

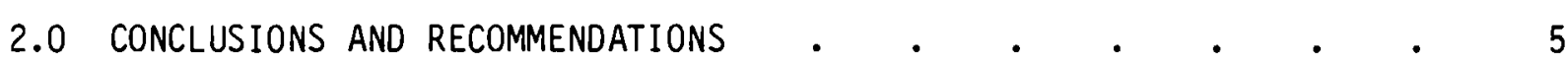

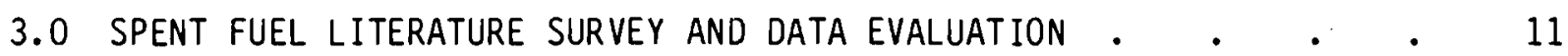

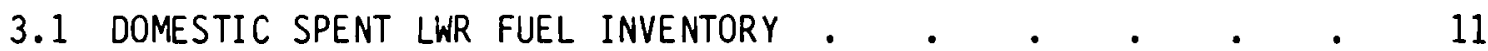

3.2 EXPERIENCE WITH DAMAGE TO FUEL FROM ABNORMAL CONDITIONS IN

HANDLING AND TRANSPORTING OPERATIONS $\quad \cdot \quad \cdot \quad \cdot \quad \cdot \quad \cdot 12$

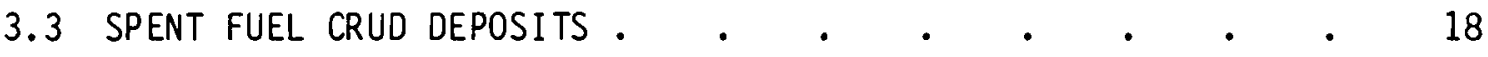

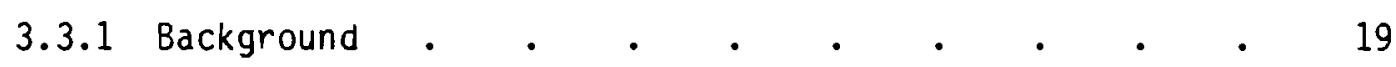

3.3.2 Crud Release, Transport, Deposition,

3.3.3 Personnel Exposure from Crud . . . . . $\quad$. 24

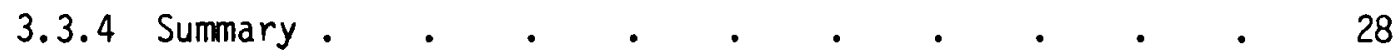

3.4 EFFECTS OF EXTENDED WATER STORAGE ON SPENT FUEL . . . $\quad$ - 30

4.0 THRESHOLD LIMITS FOR SPENT LWR FUEL BUNDLES • • • • • • • • 33

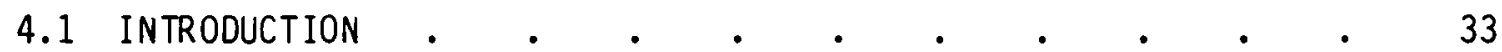

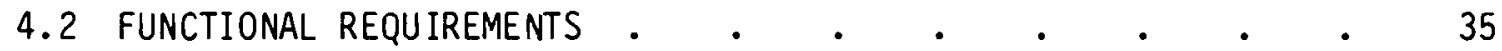

4.2.1 Radionuclide Containment $\quad . \quad$. $\quad . \quad$. $\quad . \quad$. 35

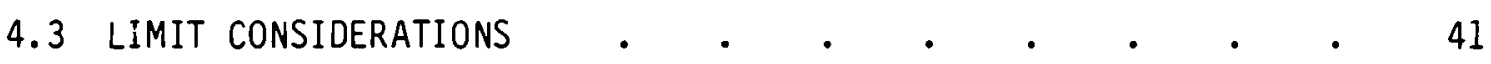

4.3.1 Interim Pool Storage Limits ..$\quad$. . . . . 47

4.3.2 Temperature Threshold Effects for Fuel in

4.3.3 Threshold Limits for Strain . . . . . . 53

4.3.4 Threshold Limits for Shock and Vibration . . . 53

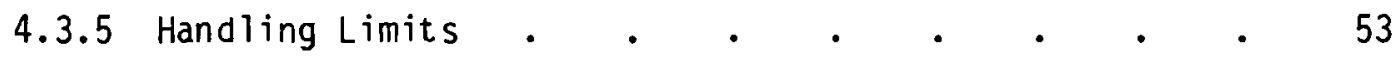


4.3.6 Transport Limits . . . . . . . . . . 55

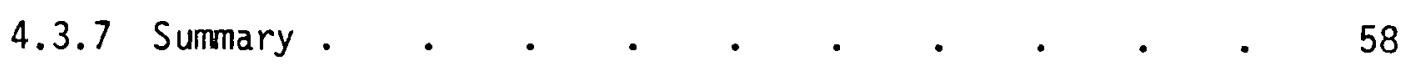

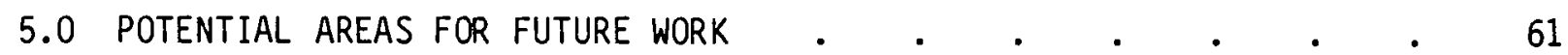

5.1 AREAS WHERE SUPPLEMENTAL DATA WOULD BE USEFUL — . . . 61

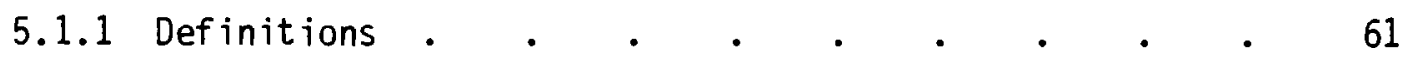

5.1.2 Detection of Incipiently Failed Fuel Rods . $\quad . \quad$. 61

5.1.3 Punctured Fuel Rods That Resealed . . . . . 62

5.1.4 Changes in Fuel Design and Duty . . . . . . 62

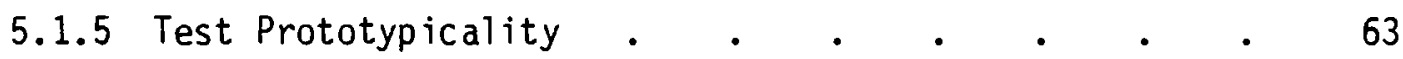

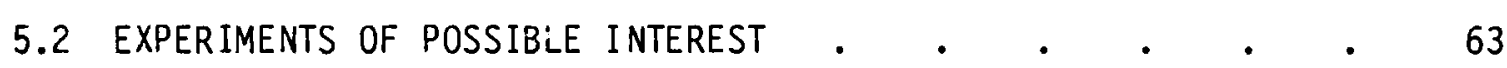

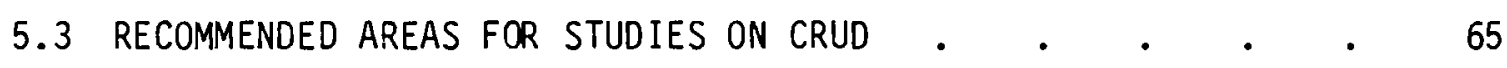

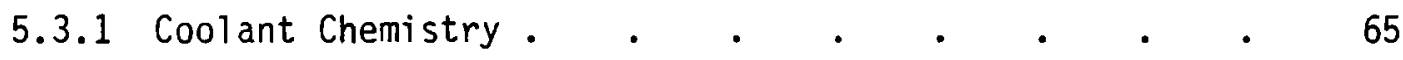

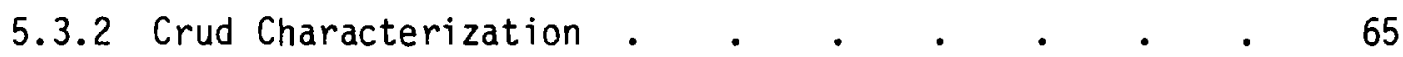

5.3 .3 Crud Behavior . . . . . . . . . . . 66

5.3 .4 Crud on Shipped Fuel . . . . . . . . 67

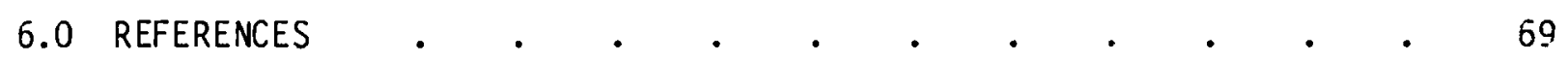

APPENDIX - SUMMARY OF EXPERIENCE WITH FUEL DAMAGE CAUSED BY
ABNORMAL CONDITIONS DURING HANDLING AND TRANSPORT. $\quad . \quad$. A.1

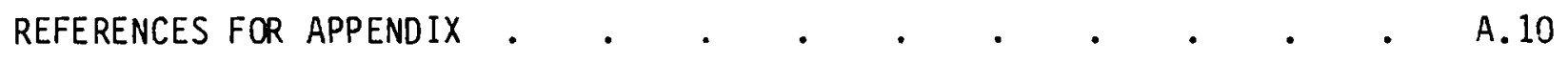




\section{FIGURES}

1 Typical Crud Deposition Patterns on Individual Fuel Rods . $\quad 21$

2 Decay of Various Nuclides of Potential Interest to Fuel Crud and Storage Pool Water Activity . . . . . . . 26

3 Activity Buildup Factor for Yearly Charging of Constant Nuclide Activity

\section{TABLES}

1 Nuc lear Capacity Growth Projection: 1982 to 2000 . $\quad$. 2

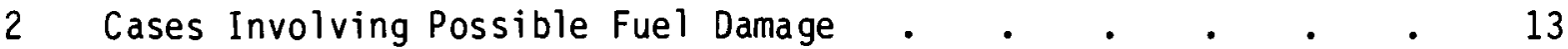

3 Number of Fuel Bundles That Tilted, Fell, or Dropped During Various Operations.

4 Some Reported Fuel Bundle Drop Distances and Drop Frequencies . 14

5 Damage Sustained by BWR Fuel Rods and Bundles . . . . . 15

6 Damage Sustained by PWR Fuel Rods and Bundles . . . . . 16

7 Observed Fuel Crud Structures at Various PWRs and BWRs . $\quad 19$

8 Observed Chemical Compositions for Fuel Crud from Various

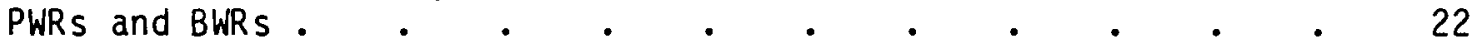

$9 \quad$ Fuel Crud Activity Data for Various PWRs and BWRs $\quad$ - $\quad$ - $\quad 25$

10 Fuel Crud Thickness Values Reported for Various PWRs and BWRs . 27

11 Degradation Mechanisms and Other Effects Being Addressed

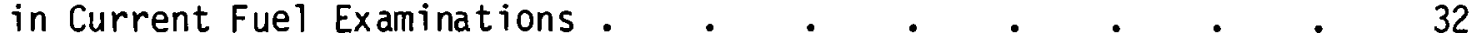

12 Mechanical Design Parameters for PWR Fuels . . • • . 36

13 Mechanical Design Parameters for BWR Fuels . . . . . 37

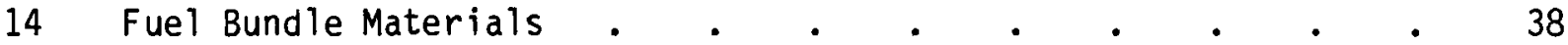

15 Recommended Cladding Temperature Threshold Limits for Nonbreached Fuel Rods 
16 Recommended Cladding and Fuel Temperature Threshold Limits for Breached Fuel Rods . . . . . . . . .

17 Weight of Metal Released to the Primary System of a 1000-MWe PWR 


\subsection{INTRODUCTION}

For the disposition of spent fuel from light-water reactors (LWRs), whether it is moved to interim storage, to fuel reprocessing, or to a disposal facility (if spent fuel is declared a waste), the expected condition of fuel rods or fuel bundles(a) upon arrival at their destination must be adequately defined to support design efforts and operational planning. Recent U.S. Department of Energy (DOE) projections of the installed capacity for domestic boiling water reactors (BWRs) and pressurized water reactors (PWRs) for each year from 1982 to 2000 are presented in Table 1.

In current planning for future storage of spent fuel, serious consideration is being given to storing containers of fuel rods rather than discrete fuel bundles. Fuel bundles would be mechanically disassembled and fuel rods would be repacked into close-packed arrays in a container--for example, a thin stainless steel (SS) can or a new grid structure. ${ }^{(6)}$ Rod consolidation would increase (possibly as much as double) the storage capacity of a facility or the shipping capacity of a cask but would also provide a greater chance for mechanical damage to the fuel rods during the disassembly/repacking process. Rod storage has not yet been licensed by the U.S. Nuclear Regulatory Commission (NRC); however, Maine Yankee has requested a license amendment to permit this type of storage. ${ }^{(6)}$ DOE and the Tennessee Valley Authority (TVA) are developing plans as part of a multiphase program to demonstrate rod consolidation with about 10 or 12 fuel bundles that involve unirradiated and irradiated fuet.

The designs of spent fuel receiving, handling, storage, reprocessing, or disposal facilities require information on the expected condition of the spent

(a) The terms "fuel bundles" and "fuel assemblies" are used interchangeably in the nuclear industry. Typically, the former term is associated with BWRS and the latter is associated with PWRs. The term "fuel bundles" will be used in this report because there are nearly twice as many bundles as as semblies now in storage. 
TABLE 1. NUC lear Capacity Growth Projection: 1982 to 2000(a)

\begin{tabular}{|c|c|c|c|}
\hline Year & BWR Type & $\begin{array}{l}\text { city, GWe } \\
\text { PWR Type }\end{array}$ & Total \\
\hline 1982 & 18.9 & 42.1 & 61.0 \\
\hline 1983 & 24.2 & 50.2 & 74.4 \\
\hline 1984 & 27.4 & 57.8 & 85.2 \\
\hline 1985 & 29.7 & 62.1 & 91.8 \\
\hline 1986 & 31.6 & 69.4 & 101.0 \\
\hline 1987 & 33.8 & 78.6 & 112.4 \\
\hline 1988 & 35.1 & 79.8 & 114.9 \\
\hline 1989 & 35.1 & 83.3 & 118.4 \\
\hline 1990 & 37.2 & 84.2 & 121.4 \\
\hline 1991 & 37.2 & 85.3 & 122.5 \\
\hline 1992 & 39.6 & 86.2 & 125.8 \\
\hline 1993 & 42.9 & 87.5 & 130.4 \\
\hline 1994 & 42.9 & 90.0 & 132.9 \\
\hline 1995 & 45.3 & 90.0 & 135.3 \\
\hline 1996 & 47.6 & 93.0 & 140.6 \\
\hline 1997 & 49.6 & 97.0 & 146.6 \\
\hline 1998 & 51.9 & 100.7 & 152.6 \\
\hline 1999 & 52.9 & 105.3 & 158.2 \\
\hline 2000 & 55.3 & 109.1 & 164.4 \\
\hline
\end{tabular}

(a) From Reference 7, DOE/RL-82-1

LWR fuel when it arrives at its destination. As a result, a study was initiated in fiscal year (FY) 1980 at Pacific Northwest Laboratory (PNL) ${ }^{(a)}$ for DOE to determine the probable condition of spent LWR fuels upon arrival at a storage, reprocessing, or repository facility after extended storage in water and subsequent handling and transport. The study was initially conducted

(a) Operated for DOE by Battelle Memorial Institute. 
through DOE's Transportation Technology Center at Sandia National Laboratories, but the third (final) phase of the study was not funded in FY 1982 because of budget cuts and reorientation of DOE programs. Because the information was useful to DOE's Commercial Spent Fuel Management (CSFM) Program at PNL, the unpublished results of the two completed phases were combined to form this report for the CSFM Program.

This report describes findings on: 1) the domestic spent LWR fuel inventory, 2) experience with damage to fuel from abnomal conditions in handling and transporting operations, 3) deposits of corrosion products (crud) on spent fuel, 4) the effects of extended water storage on spent fue 1, 5) threshold limits (a) for storing, handling, and transporting spent LWR fuel, and 6) areas where supplemental data would be useful and where possible experiments with irradiated fuel may be needed.

(a) Those conditions at which fuel bundle degradation and failure mechanisms are expected to begin to be activated, especially those that may cause the loss of fuel rod cladding containment integrity for both free volatile and/or nonvolatile solid radionuclides. 


\subsection{CONCLUSIONS AND RECOMMENDATIONS}

Very few fuel bundles have sustained major mechanical damage due to handling operations, very few fuel rods have been broken during fuel bundle disassembly operations, and very few fuel bundles are known to have suffered damage from nomal transport. In most cases involving damage from handling, only minor degradation of fuel bundle components was observed with no breaching of the fuel rod cladding or release of radioactive gases even in those cases where fuel bundles were dropped as far as 1.5 to $9 \mathrm{~m}$ ( 5 to $30 \mathrm{ft}$ ) through water and impacted other fuel bundles or the bottom of the spent fuel storage pool.

There is limited experience ${ }^{(a)}$ of statistical significance regarding transport of spent LWR fuel to and subsequent handling at reprocessing and/or storage facilities. This experience includes at least some LWR fuel bundles that have sustained damage and/or cladding failure during prior duty. In general, this transport and handling experience apparently did not involve any uncontrolled release of significant amounts of volatile, aerosol, or solid particulate radionuclides. Based on this transport and handling experience, it seems reasonable to believe that the limits and procedures currently employed can continue to be used on at least an interim basis.

Results from recent studies ${ }^{(8-13)}$ provide a basis to suggest that spent LWR fuel may reside for several decades in interim water storage pools without significant degradation or adverse effects on the arrival condition of the spent fuel at a terminal storage repository.

There are evolutionary fuel designs (e.g., prepressurization) and/or potential changes in normal duty cycles (e.g., extended burnup or load/demand following operation) that are not represented to any significant extent in current interim pool storage experience. Limits and procedures that are applicable to spent fuel now in interim pool storage may not be applicable to those evolutionary fuels now approaching the end of their duty cycles.

(a) Over 1600 LWR fuel bundles have been transported to a domestic reprocessing facility, and over 1950 LWR fuel bund les have been transported to domestic independent spent fuel storage installations. 
The potential hazard of loss of fuel rod cladding containment integrity for free volatile and/or nonvolatile solid radionuclides that may result in worker, public, and/or environmental impacts is expected to be greatest for those spent fuel rods that have sustained some damage short of cladding failure during prior duty; the hazard is generally intermediate for sound spent fuel rods and minimal (if temperatures are controlled) for already-failed rods. (a) There are virtually no statistics on fuel rods with cladding that may have been damaged to some degree short of failure.

It is very difficult to estimate how much crud might adhere to spent LWR fuel in future shipments. Insufficient data exist about crud deposition and the behavior of crud. All receiving facilities (especially dry ones) need to be able to accommodate crud on spent LWR fuel and to deal with the possibility of loose crud.

Rod consolidation, which involves the mechanical disassembly of spent fuel bundles and repacking of the fuel rods into a container, would increase (possibly as much as double) the capacity of spent fuel storage facilities. However, it would also provide a greater opportunity for mechanical damage to fuel rods during the disassembly/repacking operation.

Current engineering practice, even as required for code applications (ASME, ANSI, etc.), gives littie or no attention to the mechanics of response of "already-degraded" component materials and/or "already-damaged" bundles or structures. Specification of limits applicable to components, fuel bundles, or structures that are already degraded or damaged to an unknown extent requires extensive development.

Among the cumulative damage rules, the strain energy absorption to failure (SEAF) concept offers an approach that includes environmental effects in addition to temperature and creep, fatigue, thermal, mechanical, and impact loading modes. However, use of SEAF as a cumulative damage rule or a failure criterion is limited and untested for the impact mode of loading.

(a) If necessary, irradiated fuel bundles with known failed fuel rods may be canned prior to shipment. 
Accelerometers used on casks during shipping and handling would ident ify spent fuel rods that may have sustained damage as a result of mishaps. Improved and automated handling techniques for spent fuel rods would be beneficial.

Preliminary limits for interim storage, handling, and normal transport (a) of spent LWR fuel are suggested as follows:

- interim storage in water

a) fue 1-to-cladding interface temperatures of $\leq 620 \mathrm{~K}\left(350^{\circ} \mathrm{C}\right)$ for nonfailed fuel rods

b) exposed fue 1 surface temperatures of $\leq 570 \mathrm{~K}\left(300^{\circ} \mathrm{C}\right)$ for failed fuel rods

- handling - current load/trip limits in force at the reactor and at interim storage pool facilities; it is presumed that the load/trip setting at all LWR facilities (for example, for cranes and other handling equipment) is 1.5 times the fuel bundle weight

- normal transport

a) fuel-to-cladding interface temperatures of $\leq 620 \mathrm{~K}\left(350^{\circ} \mathrm{C}\right)$ for nonfailed fuel rods

b) exposed fuel surface temperatures of $\leq 670 \mathrm{~K}\left(400^{\circ} \mathrm{C}\right)$ for failed fue 1 rods.

If spent fuel rods with unbreached Zircaloy cladding were vented to relieve internal gas pressure--which would reduce concerns about cladding stress rupture, stress corrosion cracking (SCC), and mechanical over load--and subsequently resealed, the threshold temperature 1 imit for such rods in dry storage in helium could be increased to perhaps $770 \mathrm{~K}\left(500^{\circ} \mathrm{C}\right)$. It appears that threshold 1 imit conditions for spent fuel rods vary according to the state of degradation; thus, sorting fuel rods for storage under appropriate threshold conditions could be considered.

Areas for future work to characterize spent fuel conditions are suggested in Section 5.0, which includes a list of areas where supplemental data would

(a) Higher limit would be allowable for transport accidents. 
be useful, a list of experiments of possible interest, and a list of recommended areas for studies on crud. Items included in these lists are briefly described below:

- Develop a glossary of spent LWR fuel terminology (for example, provide unifom definitions for failed fuel and abnomal degradation of fue 1).

- Develop a means to nondestructively differentiate bet ween spent fue 1 rods that are sound and spent fuel rods that have incipient defects. (a) Detection of failed fuel rods is a reasonably we 11established procedure, but the detection of incipiently failed rods is not. (3-5) Fuel rods with incipient cladding failures are expected to represent the most likely safety concern in handing/ transporting operations.

- Continue the search for data on damage sustained by irradiated LWR fuel during handling and transporting operations, placing particular emphasis on damage to fue 1 rods.

- Conduct experiments with unirradiated fuel rods (sound and intentionally defected types) in a laboratory and with irradiated fue 1 rods (sound and failed types) in a spent fuel pool and/or a hot cell facility to simulate the handling schemes associated with proposed rod consolidation methods.

- Perform studies to obtain more data on crud deposition on spent fuel; focus on the following areas: effects of coolant chemistry on crud deposition, crud characterization, crud behavior, and projections of the amount of crud on fuel in future shipments.

- Continue the study to refine threshold limits for fuel degradation and fuel failure during handling and transporting operations; place increased emphasis on fue 1 rods, proposed rod consolidation operations, and dry operations.

(a) Fuel rods with incipient defects have sustained some damage short of cladding failure (cracks are present that extend part way through the wall of the cladding). 
- Conduct stress rupture testing of spent fuel rod cladding.

- Perform experiments to determine the threshold stress intensity, ${ }^{(a)}$ $K_{\text {I sCC }}$, for SCC of Zircaloy cladding on spent fuel rods.

- Conduct experiments to establish the allowable acceleration that can be tolerated by fuel bundles, fuel rods, and containers of closepacked arrays of fuel rods during handling, transporting, and packaging without causing excessive damage.

- Assemble data on the effectiveness of resealing techniques (used on fuel rods that are intentionally punctured in the spent fuel pool to obtain gas release data) during subsequent interim storage of and handling/transporting operations with such rods.

- Collect data on the behavior of irradiated fuel that incorporates new fuel design and duty changes. For example, data are needed on prepressurized fue 1 rods, on Zircaloy-clad fuel rods that incorporate remedies for pellet-cladding interaction (PCI), and on extendedburnup fuel.

- Consider well-designed tests of the limiting conditions. Such tests can often yield a large amount of useful information without having to be prototypic (since there are no typical reactor cycles, it is difficult to characterize "typical" fuel behavior).

- Conduct an experiment that would confirm the behavior postulated in this report for already-damaged fuel rods.

- Collect experimental data on impact loads during transport of fue 1 bundles or containers of close-packed arrays of fuel rods that involve sound fuel rods and fuel rods that were al ready damaged in prior duty.

- Identify and quantify the effects of interstitial-dislocation interaction in Zircaloy.

(a) The threshold stress intensity is the lowest value of stress intensity at which iodine-induced slow crack growth can occur under plane strain, linear elastic conditions. 


\subsection{SPENT FUEL LITERATURE SURVEY AND DATA EVALUATION}

PNL conducted a literature survey to obtain data on the domestic spent LWR fuel inventory, experience with damage to fuel from abnomal conditions in handling and transportation operations, spent fuel crud deposits, and effects of extended water storage on spent fuel. The results of the survey and the evaluation of the data are discussed below.

\subsection{DOMESTIC SPENT LWR FUEL INVENTORY}

There are currently nearly 30,000 domestic spent LWR fuel bundles in storage in water-filled pools at reactor sites and independent spent fuel storage installations. (1) of those, about two-thirds are from domestic BWRs and about one-third are from domestic PWRs. About $95 \%$ of these fuel bundles contain fuel rods with Zircaloy cladding; about $5 \%$ contain fuel rods with stainless steel cladding. $(8,9)$

Through 1976, a total of 2290 domestic spent LWR fuel bundles were known to contain one or more defective fuel rods (including leakers and rods with breached cladding); fewer than 300 of these bundles have been reprocessed.

Presently, Nuclear Fuel Services, Inc., has over 100 fuel bundles with one or more leaking fuel rod in storage at their pool. (10) The General Electric Company-Morris Operation currently has several hundred fuel bundles in storage at their pool that developed one or more defect during reactor operation. (10)

In the past, spent LWR fuel has been shipped wet cr dry. Nearly 2,000 fuel bundles $(a)$ have been transported to the two independent spent fuel storage installations. $(10,15,16)$ In general, it does not appear that transporting the fuel contributed to the loss of fuel rod cladding integrity. Although there is little information available concerning damage to fuel during shipping, the effect of transportation on cladding integrity was the

(a) 1196 to General Electric Company-Morris Operation and 756 to Nuclear Fue 1 Services. 
subject of one limited study in $1980^{(17)}$ that involved 167 fuel bundes that were shipped wet (151 with Zircaloy-clad fuel rods and 16 with SS-clad fuel rods) and 15 fuel bundles that were shipped dry ( 5 with Zircaloy-clad fuel rods and 10 with SS-clad fuel rods). It was concluded in that study that the data revealed no evidence that transportation contributed to cladding integrity loss. However, it was also concluded that the data could not validate the absence of cladding integrity loss.

Wet shipments of LWR fuel are not prohibited by the NRC; however, nearly all of the shipping casks currently in use are licensed for only dry shipments.

\subsection{EXPERIENCE WITH DAMAGE TO FUEL FROM ABNORMAL CONDITIONS IN HANDLING AND TRANSPORTING OPERATIONS}

This section describes the findings of the survey and analyzes available information on the damage to irradiated LWR fuel as a result of handing/ transporting operations. Pertinent data are included from earlier work performed by PNL for the U.S. Atamic Energy Commission under the Nuclear Fuel Reliability Program $(18,19)$ and for the NRC under the Fuel Operational Performance Program. (a)

The current PNL study includes an evaluation of 89 cases (72 domestic and 17 foreign) in which damage to fuel occurred or may have occurred during handling and/or transporting operations (see Table 2). Irradiated fuel was involved in all but 5 of the 89 cases. Of those cases where damage occurred during fuel handing, 52 were associated with receiving fuel at the reactor, 54, with fuel moves at reactor cores; 15, with fuel handling and cask loading at spent fuel pools; 1 , with an interim fuel storage facility; 3 , with foreign reprocessing plants; and 1 , with a hot cell facility. In three cases, fue 1 was found or suspected to be damaged during transport: one case involved fresh fuel shipments to a reactor, and two cases involved shipments of irradiated fuel from reactors.

(a) F IN No. B-2151 in 1978. 
TABLE 2. Cases Involving Possible Fuel Damage Operation

Receiving new fuel

Refueling reactor core

Storage and handling of fuel at spent fuel pool

Transporting irradiated fuel

Handling irradiated fuel after shipment

TOTAL

Number of Cases

2

54

15

13

$\frac{5}{89}(a)$

(a) 72 domestic and 17 foreign.

Most fuel bundles with defective fuel rods that are stored in domestic pools are not canned. Indications from several studies are that radiation releases from defects in the fuel rod cladding are small during pool storage. (9)

Damage to fuel bundles and fuel rods as a result of handling is generally detected by visual techniques (direct observation, binoculars, periscope, or closed-circuit television). Fuel bundles with fuel rods with breached cladding can also be detected by gas release, radiation monitoring, or leak testing (sipping). Damage to fuel rods can also be detected by eddy-current and ultrasonic techniques.

Based on the results of PNL's current study, the fuel damage experience from abnormal handling and transporting operations is summarized in the Appendix; the results are also described in a recent paper. (20) In most cases involving handling damage, minor degradation of fuel bundle components resulted in no breaching of the fuel rod cladding or release of radioactive gases or solids, even in those cases where fuel bund les were dropped (Table 3) as far as 1.5 to $9 \mathrm{~m}$ ( 5 to $30 \mathrm{ft}$ ) through water and impacted other fuel bundles or the bottom of the spent fuel storage pool. Tables 3, 4, 5, and 6 were abstracted from the information in the Appendix. In comparing domestic and foreign LWR fuel data with Canadian fuel data, it should be noted that most LWR fuel bundles have an active fuel column length of about $3.66 \mathrm{~m}$ 
TABLE 3. Number of Fuel Bundles That Tilted, Fell, or Dropped During Various Operations

\section{Operation}

Receiving new fuel

Refueling reactor core

Storage and handling of fuel at spent fuel pool

Handling irradiated fuel after shipment:

- interim fuel storage facility

- foreign reprocessing plants

- hot cell facility

TOTAL

Bundle type:

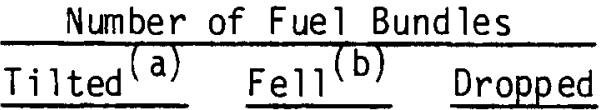

2

2
1

7

5

1

1


TABLE 5. Damage Sustained by BWR Fuel Rods and Bundles(a)

\begin{tabular}{|c|c|c|c|}
\hline Damage & $\begin{array}{c}\text { Number } \\
\text { of Cases } \\
\end{array}$ & $\frac{\text { Number }}{\text { Rods }}$ & $\begin{array}{l}\text { Involved } \\
\text { Bundles }\end{array}$ \\
\hline Grappling problem & 8 & & \\
\hline Spacer grids damaged & 3 & & $3(b)$ \\
\hline Lower tie plate damaged & 2 & & 2 \\
\hline Bail deformed & 2 & & 2 \\
\hline Unspecified damage from handling & 2 & & a few \\
\hline Spring clips hung up on core grid & $\overline{1}$ & & 3 \\
\hline Damage by fueling machine & 1 & & some \\
\hline Mechanical interference & 1 & & some \\
\hline Bundle twisted & 1 & & some \\
\hline Bundle bowed & 1 & & 1 \\
\hline Channel spacers bent or disturbed & 1 & & $\begin{array}{l}\operatorname{many} \\
(\text { at } 1 \text { BWR })\end{array}$ \\
\hline Channel deformed & 3 & & 5 \\
\hline Channel fell off bundle & 1 & & 1 \\
\hline Rod bowed & 1 & (c) & (c) \\
\hline Rod misplaced (unaccounted for) & 1 & 1 & \\
\hline Rod dropped & 1 & & \\
\hline Rod fell out of bundle & 1 & all (c) & 1 \\
\hline Rod broken during handling & 1 & $a f_{e w}(d)$ & \\
\hline
\end{tabular}

(a) In addition to those BWR fuel bundles that tilted, fell, or were dropped (see Table 3 ).

(b) Spacer grids extensively damaged on one bundle, which may result in less than full support for fuel rods.

(c) Number not stated.

(d) Bundle type not stated (may be BWR and/or PWR).

(144 in.). The Canadian reactors are natural uranium fueled and heavy-water cooled and use short (0.495-m or 19.5-in.) fuel bundles. In contrast to LWRs, the Canadian reactors use on-line refueling equipment.

Table 3 shows that in each of four domestic cases an irradiated fuel bundle tilted or tipped and came to rest against another object (not a fuel bundle). In the 13 cases ( 9 domestic and 4 foreign) involving irradiated fuel, 2 bundles fell from a vertical to a horizontal position and 11 bundles were dropped. In the two domestic cases involving fresh (unirradiated) fuel, two fuel bundles were also dropped. About two or three times as many BWR bundles as PWR bundles (which each weigh about 290 to $320 \mathrm{~kg}$ and 580 to $700 \mathrm{~kg}$, respectively) were involved. Of the three bund les in Table 4 that were dropped the greatest distances, one fell $6.1 \mathrm{~m}(20 \mathrm{ft})$, one fell $8.0 \mathrm{~m}$ 
TABLE 6. Damage Sustained by PWR Fuel Rods and Bundles(a)

\begin{tabular}{|c|c|c|c|}
\hline Damaoe & $\begin{array}{l}\text { Number } \\
\text { fo }\end{array}$ & Number In & rolved \\
\hline Refueling problem $(\mathrm{b})$ & $\frac{8}{8}$ & Rods & $\frac{\text { Bundles }}{>10}$ \\
\hline Grappling problem & 2 & & $>1$ \\
\hline Spacer grids damaged & 9 & & $>152^{(c)}$ \\
\hline Upper nozzle broken off bundle & 3 & & 4 \\
\hline Upper nozzle damaged & 1 & & 1 \\
\hline Lower nozzle damaged & 1 & & 1 \\
\hline Bundle skeleton/wrapper/can damaged & 1 & & 1 \\
\hline Nozzle springs bent or broken & 2 & & $>4$ \\
\hline Bent nut capture devices (20) & 1 & & (d) \\
\hline Bundle bumped or lower nozzle jarred & 2 & & 2 \\
\hline Bundle hit by another object & 2 & & 2 \\
\hline Bund le twisted & 1 & & 1 \\
\hline Unspecified damage due to handling & 3 & & $>2$ \\
\hline Damage due to leveling bolts and shims & 1 & & (d) \\
\hline $\begin{array}{l}\text { Object }{ }^{(e)} \text { difficult to remove from } \\
\text { fuel bundle }\end{array}$ & 6 & & 8 \\
\hline Rod bent or damaged & 2 & 4 & 2 \\
\hline Rods bowed & 1 & & 1 \\
\hline Rod bowed outside bundle envelope & 1 & 1 & 1 \\
\hline $\begin{array}{l}\text { Rods broken during handling and } \\
\text { bundle disassembly operations }\end{array}$ & 2 & $1 ;$ a few $^{(f)}$ & \\
\hline $\begin{array}{l}\text { Rods extremely difficult to remove } \\
\text { from bundle }\end{array}$ & 1 & 4 & \\
\hline
\end{tabular}

(a) In addition to those PWR fuel bundles that tilted, fell, or were dropped (see Table 3).

(b) Due to bowed rods, control blade insertion by crane (at Palisades reactor), mispositioning, high loads during removal of bundles from core, equipment problems, etc.

(c) Extensive spacer grid damage on at least 31 bundles. Such damage can result in less than full support for fuel rods.

(d) Number was not stated.

(e) Such as a burnable poison rod, burnable poison assembly, secondary source assembly, or plugging device.

(f) One PWR fuel rod was broken in one case; a few rods were broken in another case, but fuel bundle type was not stated (may be PWR and/or BWR). 
$(26 \mathrm{ft})$, and one $\mathrm{fell} 9.1 \mathrm{~m}(30 \mathrm{ft})$. When the irradiated BWR bundle that was dropped $1.8 \mathrm{~m}(6 \mathrm{ft}$ ) (see Table 4 ) was subsequently lifted to a vertical position, the channel fell off and the fuel rods fell out. Two cases have been identified where gas releases occurred, but only one of these cases showed a momentary release of radioactivity when the fuel bundle was moved, indicating some damage to fuel rod cladding. In that case, one irradiated fuel bundle was dropped $9.1 \mathrm{~m}(30 \mathrm{ft})$ onto another irradiated fuel bundle that released radioactivity.

Other kinds of handling damage sustained by BWR and PWR fuel rods and bundles are shown in Tables 5 and 6 , respectively. In a recent case, the top nozzle broke off from a PWR fuel bundle as it was being lifted from the storage rack in a spent fuel pool. In 12 cases involving over 155 bundles, the spacer grids were damaged during handling operations (e.g., by catching on some portion of an adjacent fuel bundle). The spacer grids were damaged enough that they provided less than full support for the fuel rods in 32 of the bundles. Two cases involved damage caused by twisting the fuel bundles. In one case with fresh fuel, handling operations resulted in bent fuel rods. In six cases involving eight PWR fuel bundles, difficulty was experienced in trying to remove an object (e.g., burnable poison rods, burnable poison assembly, secondary source, or a plugging device) from the fuel bundle. Other cases involved the following kinds of damage: top nozzles separated from cans (broken tack welds), nut capture devices bent, lower nozzles and tie plates deformed, bails deformed, channels deformed, hold-down springs deformed or broken, and fuel loss from two bundles with failed fuel rods. Several cases involved fuel rod handling. In one case, an unaccounted for spent fuel $\operatorname{rod}^{(a)}$ was found when the spent fuel pool was drained. In another case, a failed PWR fuel rod was broken during efforts at a hot cell facility to remove it from the fuel bundle, and it was extremely difficult to remove four other failed fuel rods from that bundle.

Three cases (one with fresh fuel and two with spent fuel) involved suspected or observed fuel damage during transport (see Appendix). In the fresh

(a) The upper shank of this tie rod was broken, but this did not affect the containment integrity of the fuel rod. 
fuel case, excessive lateral loads during shipment and/or handling resulted in damage to spacer grids. In the two cases with spent fuel (one domestic and one foreign), radiation releases to the casks were encountered after these fuel bundles, which contained SS-clad fuel rods, were shipped dry. In the case of the domestic spent fuel, the one fuel bundle was known to contain failed fuel rods. The four foreign spent fuel bundles had appeared to be intact prior to shipment; however, the fuel was from a lot that had experienced fuel failures during reactor operation. In this case, fuel rods with near-failed cladding (i.e., fuel rods with incipient defects in the cladding) may have been involved.

\subsection{SPENT FUEL CRUD DEPOSITS}

Corrosion products (crud) of concern on spent fuel are released from structural materials in the primary coolant system in LWRS, deposit on core surfaces (fuel bundles), and become radioactive by neutron activation. Activated products released from the core are transported throughout the primary system by the coolant and redeposit on the primary loop surfaces. The resulting radiation fields complicate maintenance activities and costs. Crud species

are found in two forms on spent LWR fuel: loose and tenacious. (9) Loose crud is found more frequently on BWR fuel than on PWR fuel. An indication of the amount of crud to be expected on spent fuel that is to be stored or shipped is of parallel concern to managers of storage facilities and to spent fuel shippers.

The remainder of this section presents background information on crud deposition on spent fuel and discusses the following questions:

- How much crud is on spent fuel rods when they arrive at the storage pool?

- What are the characteristics of the crud, and do they change in storage?

- What are the exposure effects on personnel involved in spent fuel handling and shipping? 


\subsubsection{Background}

The term crud pertains to the particulate carried by the coolant in the primary coolant system and to deposits on the surfaces of fuel bundes, piping, heat exchanger shells, tubing, etc. The difference between these deposits and the corrosion layer intrinsic to a given structural material is that crud results primarily from mass transfer processes operating on the corrosion/ erosion products from the various structural materials in contact with the primary coolant circuit.

The degree of alkalinity is the predominant factor affecting crud deposition on fuel in both BWRs and PWRs (that is, the more alkaline, the more crud deposition). (21) The deposition mechanism(s) depends on variation in crud solubility induced by evaporation or by temperature change in the coolant. The local surface and bulk transport of constituents to and from the crud deposit along with the local environmental conditions (i.e., temperature, pressure, radiation field, heat flux) detemine the chemical state of the deposited elements and the structural characteristics of the total crud layer. (22)

The wide variation in crud structure and appearance found among several plants of different types (see Table 7) is not surprising considering the number of factors that affect crud formation. Both BWRs and PWRs report a

TABLE 7. Observed Fuel Crud Structures at Various PWRs and BWRs (22)

Type/Reactor

PWR/Point Beach (Cyc le 1)

PWR/Beznau (Cycle 1)

PWR/KWO

\section{Observations}

Very thin, relatively uniform layer.

Individual rods exhibited various discontinuous crud patterns.

Generally uniform heavy deposit with heaviest crud in peripheral zones; black.

Crud in high heat flux zones was much thinner and gray-black/ash-white.

Hard crud sublayer (18 $\mu \mathrm{m}$ or $0.7 \mathrm{mil}$ thick) compared to total crud thickness of $43 \mu \mathrm{m}(1.7 \mathrm{mil})$. 
TABLE 7. (contd)

Type/Reactor

PWR/Yankee Rowe (Core V)

BWR/Nine Mile Point

BWR/SGHWR

NRX and NRU Test Loops

BWR/Various
Observations

Bottom few centimeters of rod had adherent, lustrous black crud layer.

Intermediate region had thin $(25-\mu \mathrm{m}$ or $1-\mathrm{mi} 1$ thick) gray layer.

Top $43 \mathrm{~cm}$ (17 in.) of rods covered by loosely adherent, porous brownish-red layer $(51 \mu \mathrm{m}$ or $2 \mathrm{mils}$ thick).

Flocculent, loosely adherent crud layer.

No evidence of hard sublayer.

Presence of $\mathrm{Cu}$ caused brittle impervious layer underneath or sandwiched between layers of porous iron-rich crud; cracking observed in brittle layer.

Major crud layer consisted of porous agglomerate of very fine iron-rich particles; the brittle crud constituent had a Cu/Fe ratio of about 5.0 .

In general, crud deposits were fine-grained, porous, friable, and red (when neutral coolant used).

Presence of $\mathrm{Cu}, \mathrm{Ni}$, and $\mathrm{Zn}$ would be expected to lead to more tenacious deposit as opposed to reversible iron oxides usually observed.

Major constituent was reddish-brown flocculent material; crud structure quite sensitive to water purification system.

Deep-bed ion exchanger plants tended to yield flocculent crud, which was easily removed by brushing.

Powdered resin plants tended to yield a relatively tenacious sublayer under a flocculent outer layer; nonferrous elements tended to concentrate in sublayer.

tenacious sublayer, and crud porosity and flocculence appear to be more characteristic of BWRs although they are reported to some degree for both plant types. (22) The crud deposition pattern on fuel is generally nonuniform (see 
Figure 1). Most crud deposits have an iron-rich composition. (21) 0xides comprise most of the crud; other elements are incorporated in the crud in the form of spinels, ferrites, and/or separate oxides (see Table 8). (22)

Ten fuel rod failures at Maine Yankee in 1980 were most likely caused by external corrosion associated with excessive crud deposits, but the fuel failure mechanism was not believed to be of a core-wide degenerative type. $(23,24)$ During a 1978 inspection of 0yster creek fuel, when a fuel rod was withdrawn from an assembly, contact between the spacer grid and the fuel rod caused the crud layer to be scraped off, exposing the bare Zircaloy surface. (25) In examinations of crud on fuel at Surry-1 and Trojan, the number of rods affected and the crud thickness appeared to be burnup- and power-dependent. $(27,28)$

Semiempirical mathematical models for crud deposition have been developed, (21) based on simultaneous deposition and release (which yield an equilibrium thickness of the deposit). Under BWR conditions, the rate of crud deposition on the fuel bundle is proportional to the crud concentration in the coolant and to the square of the heat flux. Under PWR conditions, the rate of crud deposition on the fuel bundle is proportional to the crud concentration

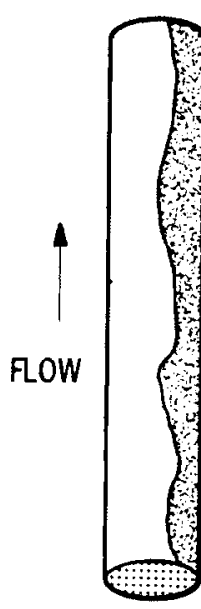

FLOW OUTLINE

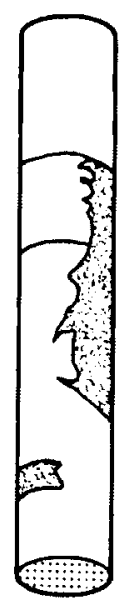

CIRCUMFERENTIAL

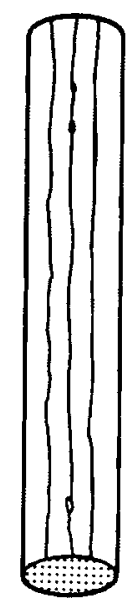

RAKED

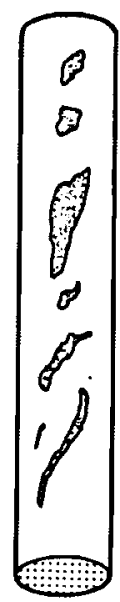

SPOTS

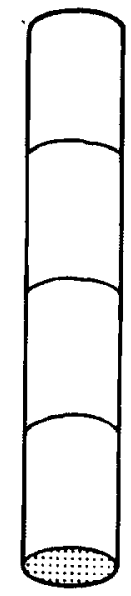

BAMBOO EFFECT

FIGURE 1. Typical Crud Deposition Patterns on Individual Fue 1 Rods (from Reference 26) 
TABLE 8. Observed Chemjcal Compositions for Fuel Crud from Various
PWRs and BWRs 22$)$ C

Type/Reactor

PWR/Point Beach

PWR/KWO

PWR/B\&W plants

BWR/various newer

BWR/SGHWR
Chemical Compound Observations

Chief constituent was a nickel ferrite of composition $\mathrm{Ni}_{x} \mathrm{Fe}_{3-\mathrm{x}} \mathrm{O}_{4}$, with $\mathrm{x}<1$.

$\begin{array}{lc}\text { Upstream } & \text { of core } \\ \mathrm{Fe}_{2} \mathrm{O}_{3} & \sim 45 \\ \mathrm{NiO}^{2} & -25 \\ \mathrm{Cr}_{2} \mathrm{O}_{3} & \sim 12 \\ \mathrm{ZrO}_{2} & \sim 2 \\ & \\ \text { Downstream, wt\% } & \text { wt } \\ \mathrm{NiO}^{2} & \sim 55 \\ \mathrm{Fe}_{2} \mathrm{O}_{3} & \sim 28 \\ \mathrm{Cr}_{2} \mathrm{O}_{3} & \sim 7 \\ \mathrm{ZrO}_{2} & \sim 2 .\end{array}$

Crud consists of $\mathrm{NiO}, \mathrm{Fe}_{3} \mathrm{O}_{4}, \mathrm{NiFe}_{2} \mathrm{O}_{4}$, $\mathrm{CoFe}_{2} \mathrm{O}_{4}, \mathrm{Co}_{x} \mathrm{Ni}_{1-x} \mathrm{Fe}_{2} \mathrm{O}_{4}$.

Major crud phase is alpha $\mathrm{Fe}_{2} \mathrm{O}_{3}$ with minor amounts of $\mathrm{Fe}_{3} \mathrm{O}_{4}$. A tenacious sublayer is generally observed under a flocculent layer with nonferrous elements tending to concentrate in sublayer; major phase of both layers is $\mathrm{Fe}_{2} \mathrm{O}_{3}$.

Under high $\mathrm{Cu}$ conditions, crud consisted of a porous layer of $\mathrm{Fe}_{3} \mathrm{O}_{4}, \mathrm{CuO}$, and some $\mathrm{Fe}_{2} \mathrm{O}_{3}$. Compact

layer consisted of $\mathrm{CuO}, \mathrm{Fe}_{2} \mathrm{O}_{3}$, and a $\mathrm{Fe} / \mathrm{Cu}$ spinel.

in the coolant and depends on the hydrodynamic forces acting on the crud particulates. The rate that the crud is released from the bundle is proportional to the crud solubility difference between the cooler bulk coolant and the hotter coolant at the fuel surface.

\subsubsection{Crud Release, Transport, Deposition, and Condition}

A recent EPRI report (29) presented an in-depth review of fuel crud behavior in LWRS. As described in that report, crud is released to the primary coolant from the corroding surfaces or from subsequent deposits within and external to the core. These subsequent deposits may occur a number of 
times depending upon hydraulic conditions, temperature, water chemistry, and flow conditions. At present, most of the available data on release rates are those associated with crud generation from the substrate material.

Crud from the corroding surfaces external to the core is usually transported to the core and deposited on fuel bundles, where it is activated and then dissolved or eroded from the fuel bundles and reprecipitated or redeposited external to the core. As a general rule, crud release rates are a fraction (about 1/2) of the corrosion rates of the substrate material and are influenced by the surface condition and by temperature, $\mathrm{pH}$, oxygen content, and coolant velocity.

Crud is transported in both the soluble and insoluble states, with concentrations typically running between 10 to $20 \mathrm{ppb}$ in an operating reactor and to above $100 \mathrm{ppb}$ during shutdown or crud bursts. The composition of crud being transported varies depending on reactor type, piping, and operating conditions.

The EPRI report ${ }^{(29)}$ points out that in the crud deposition process surface changes in suspended particles and deposition surfaces appear to play a major role. Determination of such surface changes for various reactor materialcoolant combinations is needed to establish the basis for implementing procedures to reduce crud deposition. In general, crud deposits on Zircaloy-clad fuel rods during one core cycle in PWRs range from about 1 to $50 \mathrm{mg} / \mathrm{dm}^{2}$, with the thickness ranging from 0.05 to $4 \mu \mathrm{m}$.

U.S. PWRs typically operate with coolant chemistry conditions that result in heavier crud deposits than in some foreign PWRs. (30) With BWRs, preventing the input of impurities from the feedwater system is essential to reducing crud activity in the primary coolant system. $(31,32)$

As noted in the EPRI report, ${ }^{(30)}$ crud deposition on fuel rods is highly variable even in plants of similar design. EPRI currently has a project under way involving two BWRs and two PWRs to develop operating procedures to minimize crud buildup. One plant in each pair has a light crud buildup and one has a heavy crud buildup.

$$
\text { EPRI NP-3789, aprid } 1985
$$


From Table 7, it can be seen that some of the crud deposited on the fuel in-reactor $c$ an be removed prior to the time that the fuel bundles enter the storage pool. The chemical compounds comprising the fuel crud together with the crud structure determine the susceptibility of the crud to various chemical/mechanical cleaning procedures and its stability under longer term storage in water or air environments. In a water environment, radioactivity from the crud is dominated by ${ }^{60} \mathrm{Co}$. In fuel storage pools where spent fuel with cladding defects is stored and where fission product release has occurred, the radioactivity in the water is dominated by ${ }^{137} \mathrm{Cs}$ and ${ }^{134} \mathrm{Cs}$. There is some evidence of an equilibrium between crud-bound cesium and cesium in the pool water. Crud removed during fuel handling contributes to personnel exposures because additional pool cleanup is required and more time is needed to decontaminate contaminated casks.

Crud flaking was reported ${ }^{(33)}$ in air when the fuel temperature reached $100^{\circ} \mathrm{C}$; hence, there is the possibility of crud spallation during dry handling operations. (14) The potential for fuel temperatures greater than $100^{\circ} \mathrm{C}$ for crud flaking in a spent fuel pool occurs during leak testing of fuel bund les under dry conditions (commonly called dry sipping) ${ }^{(34)}$ or under the condition of an extreme accident that drains the pool. (35) Considerably more characterization of fuel crud is required to establish any correlation of fuel temperature excursions resulting from such an unlikely extreme event with crud dry-out and dispersal as particulate material to the local environment. This problem is of minimal interest to wet storage concepts for spent fuel, but it is relevant to those using dry storage.

\subsubsection{Personnel Exposure from Crud}

The radiological hazard associated with crud on spent fuel for spent fuel storage facility and shipping personnel results from the radioactivity inventory of the crud (Table 9). The decay of various nuclides of potential interest to fuel crud and storage pool activity is illustrated in Figure 2.

The effect of crud on spent fuel storage facility and transport operations and occupational safety depends primarily on the characteristics of the nuclide 
TABLE 9. Fuel Crud Activity Data for Various PWRs and BWRs (22)

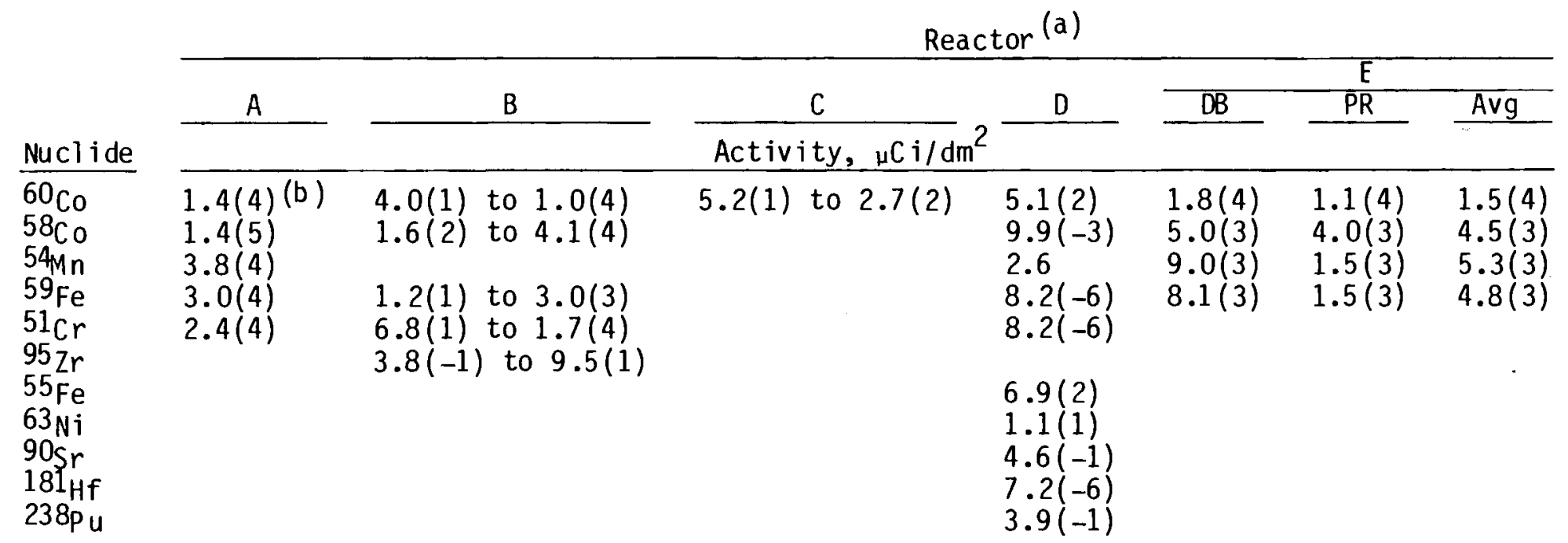

Summary Data

\begin{tabular}{|c|c|c|}
\hline Nuclide & PWR Range, $\mu \mathrm{Ci} / \mathrm{dm}^{2}$ & $\begin{array}{c}\text { and PR Data for } E) \text {, } \\
\mu \mathrm{C} i / \mathrm{dm}^{2}\end{array}$ \\
\hline${ }^{60} \mathrm{Co}$ & $4.0(1)$ to $1.4(4)$ & $1.5(4)$ \\
\hline $\begin{array}{l}58 \mathrm{Co} \\
54 \mathrm{Mn} \\
59 \mathrm{Fe} \\
51_{\mathrm{Cr}}\end{array}$ & $\begin{array}{l}9.9(-3) \text { to } 1.4(5) \\
2.6 \text { to } 3.8(4) \\
8.6(-6) \text { to } 3.0(4) \\
8.2(-6) \text { to } 2.4(4)\end{array}$ & $\begin{array}{l}4.5(3) \\
5.3(3) \\
4.8(3)\end{array}$ \\
\hline
\end{tabular}

(a) $A=P W R / Y a n k$ ee Rowe; 16.0 to $46.0 \mathrm{MWd} / \mathrm{kgu}(\mathrm{c})$; zero age.

$B=P W R / V$ arious $B \& W$ plants; zero age.

$C=$ PHWR/Douglas Point; $47 \mathrm{MWh} / \mathrm{kgU}$ to $309 \mathrm{MWh} / \mathrm{kgU}$; age unspecified.

$D=$ PWR/Shippingport; PWR-2 seed and blanket; 15.0 to $24.5 \mathrm{MWd} / \mathrm{kgU}$; fuel age about 37 months.

$E=B W R / v a r$ ious GE plants; about 12,000 effective full-power hours; zero age; DB and PR refer to deep bed ion-exchange and powdered resin water purifiers, respectively.

(b) $1.4(4)=1.4 \times 104$, etc.

(c) $\mathrm{MWd} / \mathrm{kgU}=$ megawatt day per $\mathrm{kilogram}$ of heavy metal (for example, $U=$ uranium). 


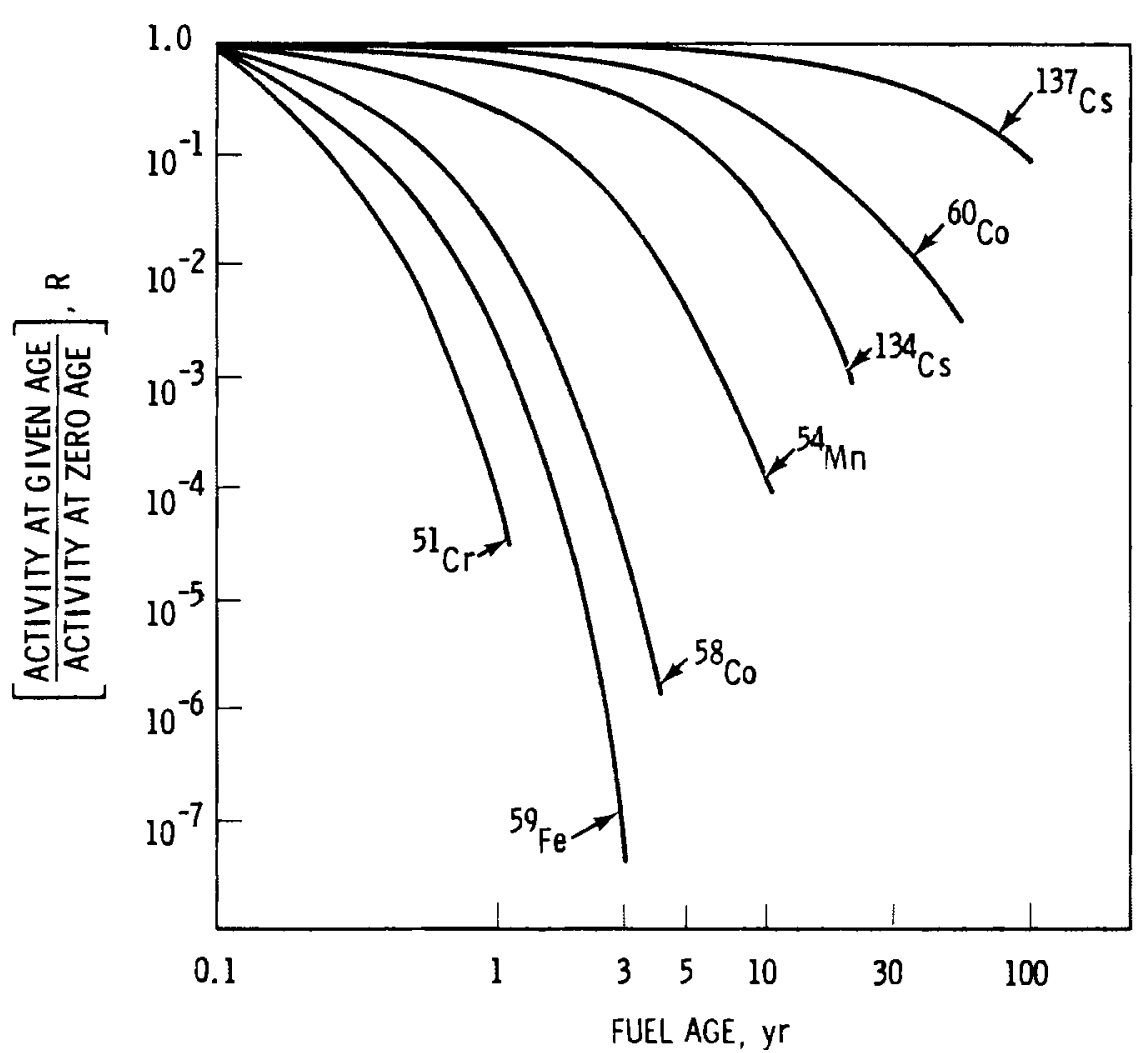

FIGURE 2. Decay of Various Nuclides of Potential Interest to Fue 1 Crud and Storage Pool Water Activity 22) (zero age means at reactor discharge)

inventory of crud particulates released to the storage pool and water system by fuel manipulation and transfer operations and by the solubility and ionexchange properties of the bound crud.

Based on the information presented in the tables and the preceding text, estimating the amount of crud on a fuel rod that is to be delivered to the storage pool or one that is to be shipped is a complex task. Measuring the amount of crud on fuel surfaces and estimating the total amount expected for a particular lot of spent fuel is the first step toward an answer. The next step is assessment of the chemical and radioactive characteristics of the crud. A compilation of crud thickness measurements (Table 10) shows that thickness values range over more than four decades, and maximum values are over $0.13 \mathrm{mi}$ 
TABLE 10. Fuel Crud Thickness Values(a) Reported for Various PWRs and BWRs $(22)$

\begin{tabular}{|c|c|c|c|}
\hline \multirow{2}{*}{ Type/Reactor } & \multirow{2}{*}{$\begin{array}{l}\text { Crud Areal Density, } \\
\mathrm{g} / \mathrm{m}^{2} \text { (mass/area) }\end{array}$} & \multicolumn{2}{|c|}{ Crud Thickness } \\
\hline & & mils & $\mu \mathrm{m}$ \\
\hline PWR / KWO & 0.5 & 1.7 & 43 \\
\hline PWR/Point Beach & 0.07 to 4.6 & 0.002 to 0.15 & 0.05 to 3.8 \\
\hline PWR/Beznau & 4.7 to 47 & 0.15 to 1.5 & 3.8 to 38 \\
\hline PWR/Saxton & 1.0 & 0.03 & 0.8 \\
\hline PWR/Obrigheim & 3.0 to 80 & 0.10 to 2.7 & 2.5 to 69 \\
\hline PHWR/Pickering & 0.01 to 0.1 & 0.0003 to 0.003 & 0.008 to 0.08 \\
\hline PHWR/Douglas Point & $2.0($ early) & 0.07 & 1.8 \\
\hline & 0.10 (recent) & 0.003 & 0.08 \\
\hline BWR/ deep-bed plant & 0.47 & 1.6 & 41 \\
\hline powdered resin & 0.14 & 0.5 & 13 \\
\hline BWR/Gentilly & 8.0 & 0.3 & 8 \\
\hline BWR/Dresden & & 1.1 & 28 \\
\hline BWR / KRB & & 4.0 & 102 \\
\hline BWR/SGHWR & & 3.0 & 76 \\
\hline BWR/SGHWR & & 5 to 6 & 130 to 150 \\
\hline
\end{tabular}

(a) Data are given to indicate the range of fuel crud thicknesses reported for various stages in the plant history and various primary water chemistries and do not imply normal fuel crud values for these plants.

(b) The following formulas for converting areal density to thickness assume the bulk density of crud to be $1.2 \mathrm{~g} / \mathrm{cm}^{3}$. The bracketed factor is the areal density given in the units indicated.

$$
t(\mu \mathrm{m})=8.3 \times 10^{-1} \times\left[\mathrm{g} / \mathrm{m}^{2}\right] \quad \mathrm{t}(\mathrm{mils})=3.9 \times 10^{-2} \times\left[\mathrm{g} / \mathrm{m}^{2}\right]
$$

( 5 mils). These values do not represent a crud layer of uniform thickness but spot observations from a variety of rod locations over a wide range of reactor exposure and spent fuel handling conditions. Zima (22) developed a crud areal density parameter that tends to mathematically smooth out the crud into a layer of uniform thickness over the fuel surface.

Zima also computed an estimate of the radioactivity inventory of an independent spent fuel storage facility (ISFSF) that is attributable to fuel crud. 
He assumed Zircaloy cladding and the Diablo Canyon Fuel Assembly Fuel Model and used values for fuel crud activity from Table 9; his results are illustrated in Figure 3.

Zima concluded that crud deposited on fuel bundles that survive reactor site manipulations and storage and transfer and cleanup operations prior to placement of the bundles in a storage pool is a relatively minor source of radioactivity input into that pool compared to the radioactivity inventory contained with in the fuel. However, if the number of failed or leaky fuel rods in the pool is limited, crud can be the major part of pool water contamination.

\subsubsection{Surmary}

Because of extensive research and development studies performed in the United States and in other countries on nuclear fuel characterization, fuel performance can be predicted with confidence. However, insufficient data are available on crud deposition on fuel and the behavior of crud; thus, exploratory work remains to be done. Based on the available information on crud, four areas are recommended for further study: coolant chemistry, crud characterization, crud behavior, and projections of the amount of crud on fuel in future shipments (see Section 5.0).

Crud deposition on fuel rods is highly variable even in plants of similar design. (30) crud on spent LWR fuel can have a very significant influence on the risk of transporting and handing operations with such fuel.

Crud on spent LWR fuel can be loose or tenacious. Loose crud is found more frequently on BWR than on PWR fuel. Adherence of crud on spent LWR fuel bundles $c$ an be increased or decreased by drying, changing the oxygen concentration in the storage pool water, or vibration during transporting operations. It is also recommended in Reference 14 that all receiving facilities, especially dry receiving facilities, be designed to adequately deal with external contamination or crud (loose and fixed) on spent LWR fuel. 


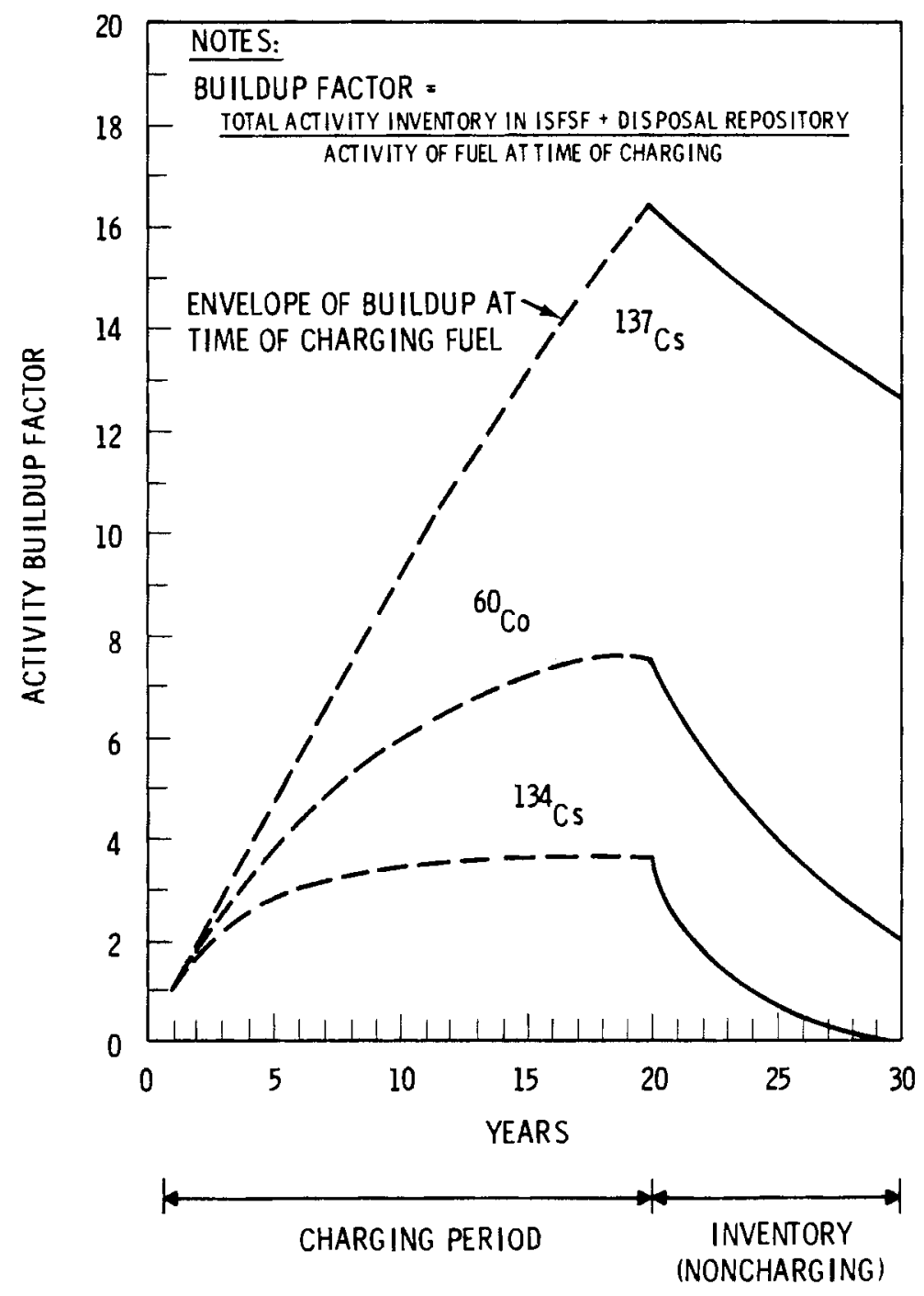

FIGURE 3. Activity Buildup Factor for Yearly Charging of Constant Nuc lide Activity. (22) ISFSF = Independent Spent Fue 1 Storage $\mathrm{Facility}$; the half-1ives for $137 \mathrm{Cs}$, $134 \mathrm{Cs}$, and ${ }^{60} \mathrm{Co}$ are $0.023 \mathrm{yr}^{-1}, 0.33 \mathrm{yr}^{-1}$, and $0.13 \mathrm{yr}^{-1}$, respectively.

Irradiating fuel to high burnup is one way of increasing uranium utilization, which is a subject of current interest. A benefit of irradiating fuel to high burnup is that it reduces the amount of spent fuel that needs to be stored. However, crud deposition on fuel may be increased by extending fuel burnup. 
It is difficult to predict how much crud will be on spent fuel rods when they are delivered to a storage facility. Changes in crud condition depend on the chemical makeup of the crud and the nature of the crud environment. It is difficult to predict changes in crud condition accurately unless the initial crud condition and the effects of the transport and storage environment are known. The exposure effects on personnel involved in spent fuel handling and storage will depend on the characteristics of the crud and the effects of handling and the storage pool environment on the crud.

Currently, reactor water chemistry is the primary control employed to minimize crud production. Close control of reactor water chemistry (especially $\mathrm{pH}$ ) and perhaps cleaning of spent fuel before shipment may be used to further reduce radiological hazards associated with handling, transporting, and storing spent fuel.

In summary, additional work is needed to define crud formation and release rates from both in-core and out-of-core deposits and to determine the residence time of crud in the reactor so that the overall process of crud release, transport, and deposition can be better understood.

\subsection{EFFECTS OF EXTENDED WATER STORAGE ON SPENT FUEL}

PNL is studying the effects of extended water storage on domestic spent

LWR fuel under the Spent Fuel and Fuel Pool Component Integrity Program, (8-13) which is sponsored by DOE. In 1977, Johnson (10) conducted a preliminary assessment of potential degradation mechanisms for extended water storage of Zircaloy-clad and SS-clad fuel. He identified the following factors-emphasized to be low-key concerns--that "... appear to require further definition, not necessarily with implied priorities:

- behavior of fuel defects as a function of defect type, cladding type, and storage conditions

- possible effects of pool temperature and water chemistry transients on the subsequent condition of stored fuel, as a function of material and pool chemistry

- effects of boric acid pool chemistry on materials behavior 
- effects of galvanic couples on the hydriding of zirconium alloys

- the degree of mechanical damage to fuel bundle materials in spent fuel shipments

- the incidence and consequences of high residual stresses in fuel bund le materials

- the possibility of progressive fission product attack on fuel cladding inner surfaces

- definition of special effects such as crud layer environments and crevice corrosion...." (10)

Several recent papers $(12,13)$ discuss fuel bundle degradation mechanisms and other fuel bundle effects (Table 11) and how they have been (or are to be) addressed in current examinations of Zircaloy- and SS-clad fuel. It was concluded that "... the current optimism regarding storage of spent LWR fuel in water pools is based on these facts:

- favorable spent fuel pool operator experience - No spent fuel pool operator to date (1980) has found evidence by visual examination or radiation monitoring that commercial water reactor fuel is degrading during water storage for periods up to nearly 21 yr for Zircaloy-clad fuel and up to 12 yr for SS-clad fuel.

- favorable indications from theoretical assessments of expected spent fuel behavior - Independent assessments by several investigators did not find a basis for expecting fuel cladding degradation to occur during pool storage.

- favorable results from nondestructive and destructive examinations of spent water reactor fuel - To date (1980), the answer has been--in all cases-that no evidence of pool-induced deterioration has been detected.

Based on these results, there appears to be a sound basis for storage of water reactor spent fuel for several decades in water pools." (12) 
TABLE 11. Degradation Mechanisms and Other Effects 3 Being
Addressed in Current Fue 1 Examinations $(12)$

Degradation Mechanisms

- Uniform Corrosion

- Crud Effects (for example, formation of differential aeration cells or concentration of aggressive species such as chlorides)

- Crevice Corrosion (fuel bundle components)

- Stress Corrosion Cracking on External Surfaces

- Galvanic Corrosion

- Galvanic Hydriding

- Pitting

- Corrosion at Cladding Defects

- Fission Product Attack

- Internal Hydriding

- External Hydriding

- Effects at Welds

Other Effects

- Appearance of Original Cut Surfaces (e.g., from earlier postirradiation examination)

- Spring Forces

- Mechanical Properties

- Fuel Swelling

- Fuel Pellet Degradation 


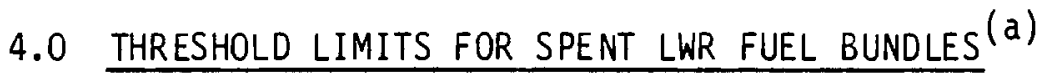

\subsection{INTROOUCTION}

Efforts were directed towards determining threshold limits for spent LWR fuel. For the purpose of this study, threshold limits are defined as those conditions at which fuel rod or fuel bundle degradation and failure mechanisms are expected to begin to be activated, especially those mechanisms that may cause the loss of fuel rod cladding containment integrity for both free volatile and/or nonvolatile solid radionuclides. The intent was to specify threshold limits for storage, handling, and transport operations that provide a margin against failure of spent LWR fuel bundles and especially failure of fuel rod cladding. Safety factors could be applied on these threshold limits, but they do not need to be large. The proposed limits may be ultraconservative for short-term abnormal events. Because of the infancy of this task, the data base for developing these threshold limits is not complete, and numerous as sumptions were required regarding long-term materials behavior. In this section of the report, the recommended limits and some of the potential consequences of these assumptions are reviewed.

In the spent LWR fuel management system, the major attention during the past several years has been on packaging for terminal storage in geologic repositories. (36-38) Significant effort has been applied to an examination of the requirements for and the development of criteria for packaging and terminal geologic storage without reprocessing to recover fissile materials. (39)

Superimposed upon the uncertainty of threshold limits are the current trends to consider 1) storing containers of fuel rods rather than discrete fuel bundles and 2) dry storage (rather than continued wet storage) after an appropriate period of wet storage. Rod consolidation, which involves the mechanical disassembly of spent fuel bundles and repacking of the fuel rods into a container, would increase the capacity of spent fuel storage facilities; however, it would also provide a greater opportunity for mechanical damage to fuel rods

(a) This section pertains primarily to LWR fuel bundles containing zircaloyclad fuel rods. 
during the disassembly/repacking operation. Close-packed rods also present an increased heat loading, which will lead to higher temperatures unless provisions are made for adequate cooling.

In spent LWR fuel management studies, it has been recognized that significant amounts of spent LWR fuel have been in interim pool storage for substantial periods of time (some fuel has been stored for nearly $21 \mathrm{yr}$ ). During this interim storage period, the spent fuel has remained in its original LWR fuel assembly configuration. Under the static, low-temperature ( $\leq 270 \mathrm{~K}$ or $100^{\circ} \mathrm{C}$ ) pool storage conditions, the fuel rod $\mathrm{cladding}$ appears to have functioned generally satisfactorily as the primary containment for radionuclides in both gaseous and solid forms.

A common denominator to placing threshold limits on specific operations involves assessing the state of degradation of the fuel rods. It appears necessary to establish a method of indexing the level of degradation for each fuel rod or array of fuel rods. (a) To assume that ail spent fuel rods have a low level of degradation may lead to failure of specific fuel rods that have a high level of degradation during shipment to and/or handling at an interim storage, reprocessing, or disposal facility.

The current inventory of spent LWR fuel and spent fuel yet to be retired from duty must eventually be moved to appropriate licensed packaging and terminal storage sites. Based on these considerations, this effort was undertaken to identify and, where possible, quantify the threshold limits applicable to interim pool storage, handling, and eventual transport to reprocessing or disposal facilities. If conditions are maintained within these limits, it is believed that acceptable integrity of the fuel bundle, especially the integrity of the fuel rod cladding, will be maintained in most cases. Exceeding the limits could mean that potential fuel degradation and failure mechanisms are being activated.

(a) Detection of failed fuel rods (i.e., other than visually ident if ied failed rods) is currently a reasonably established procedure, using either or both eddy-current and ultrasonic testing; but the detection of incipiently failed fuel rods is not. $(3,5)$ Fuel rods with incipient defects have sustained some damage short of cladding failure (cracks are present that extend part way through the wall of the cladding) during prior duty. 


\subsection{FUNCTIONAL REQUIREMENTS}

Spent LWR fuel currently in interim pool storage represents a variety of duty cycles (i.e., burnups), fuel designs and configurations, and to a lesser extent materials in structural components (see Tables 12, 13, and 14). In our estimation, there is no typical duty cycle (see Section 5.1.5), which makes it difficult to characterize "typical" fuel behavior. The current nominal design burnups for PWR and BWR fuels are $33.0 \mathrm{MWd} / \mathrm{kgU}$ and $27.3 \mathrm{MWd} / \mathrm{kgU}$, (a) respectively. (40) The current duty period is 4 to $5 \mathrm{yr}$.

A basic characteristic of all spent LWR fuel rods is that they contain radionuclides, some of which are or may be:

- volatile at virtually any temperature

- volatile at intermediate and/or high temperatures

- solid at all anticipated temperatures.

A second basic feature of all spent LWR fuel is that some number of fue 1 rods are combined and assembled into a specific geometric configuration for, among other reasons, convenience in handling (see Tables 12, 13, and 14).

Beyond these two common characteristics there can be many differences in details. Some differences are attributable and specific to plant type, duty cycle, and even chronological changes arising from operating experiences. Furthermore, it may be that the variety will increase through further evolutionary changes. Since the two common characteristics are not expected to change substantially, the two basic functional requirements are radionuclide containment and continued handleability with little or no interim ancillary packaging.

\subsubsection{Radionuclide Containment}

For interim pool storage and handling and transport to packaging and terminal storage sites, the radionuclide containment requirements are nearly the same as for solidified high-level waste (SHLW): the prevention of a deleterious dose rate to facility personnel, to the general population, and to the

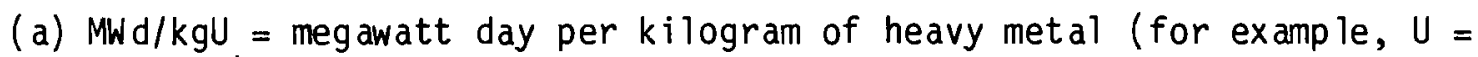
uranium). 
TABLE 12. Mechanical Design Parameters for PWR Fuels

\begin{tabular}{|c|c|c|c|c|c|c|}
\hline \multirow{2}{*}{ Parameter } & \multicolumn{6}{|c|}{ PWR Fuel Bundles } \\
\hline & \multicolumn{2}{|c|}{ Westinghouse } & \multicolumn{2}{|c|}{ Combustion Engineering } & \multicolumn{2}{|c|}{ Babcock \& Wilcox } \\
\hline Rod Array & $15 \times 15$ & $17 \times 17$ & $14 \times 14$ & $16 \times 16$ & $15 \times 15$ & $17 \times 17$ \\
\hline \multicolumn{7}{|l|}{ Fuel Bundles: } \\
\hline $\begin{array}{l}\text { Transverse Dimension, } \mathrm{cm} \text { (in.) } \\
\text { Assembly Weight, } \mathrm{kg}(\mathrm{lb}) \\
\text { Overall Bundle }\end{array}$ & $\begin{array}{l}21.4(8.426) \\
645(1420)\end{array}$ & $\begin{array}{l}21.4(8.426) \\
658(1450)\end{array}$ & $\begin{array}{l}20.3(7.98) \\
582(1280)\end{array}$ & $\begin{array}{l}20.3(7.98) \\
657(1446)\end{array}$ & $\begin{array}{l}21.7(8.536) \\
--\end{array}$ & $\underset{--}{21.7}(8.536)$ \\
\hline Length, $\mathrm{cm}$ (in.) & $410(161.3)$ & $410(161.3)$ & $398(156.7)$ & $449(176.8)$ & -- & $421(165.6)$ \\
\hline \multicolumn{7}{|l|}{ Fuel Rods: } \\
\hline $\begin{array}{l}\text { Number per Bundle } \\
\text { Rod Pitch, cm (in.) } \\
\text { Length, cm (in.) } \\
\text { Fueled Length, cm (in.) } \\
00, \mathrm{~cm} \text { (in.) } \\
\text { Diametral Gap, cm (in.) } \\
\text { Clad Thicknes } 9 \mathrm{~cm} \text { (in.) } \\
\text { Clad Material(a) }\end{array}$ & $\begin{array}{l}204 \\
1.43(0.563) \\
386(152.0) \\
366(144.0) \\
1.07(0.422) \\
0 . \overline{0} 6(0.030) \\
\operatorname{Zry-4}\end{array}$ & $\begin{array}{l}264 \\
1.26(0.496) \\
386(152.0) \\
366(144.0) \\
0.95(0.374) \\
0.017(0.0065) \\
0.057(0.0225) \\
\text { Zry-4 }\end{array}$ & $\begin{array}{l}176 \\
1.47(0.58) \\
372(146.5) \\
347(136.7) \\
1.12(0.440) \\
0.022(0.0085) \\
0.066(0.026) \\
\operatorname{2ry}-4\end{array}$ & $\begin{array}{l}236 \\
1.29(0.506) \\
410(161.6) \\
381(150.0) \\
0.97(0.382) \\
0.018(0.007) \\
0.064(0.025) \\
\text { Zry-4 }\end{array}$ & $\begin{array}{l}208 \\
1.44(0.568) \\
=-(144.0) \\
366(09(0.430) \\
1.09(0.007) \\
0.018(0.067(0.0265) \\
0.067 \\
\text { Zry-4 }\end{array}$ & $\begin{array}{l}264 \\
1.27(0.501) \\
388(153.0) \\
363(143.0) \\
0.96(0.379) \\
0.020(0.008) \\
0.060(0.0235) \\
\text { Zry-4 }\end{array}$ \\
\hline \multicolumn{7}{|l|}{ Fuel Pellets: } \\
\hline $\begin{array}{l}\text { Density, \& } \mathrm{TO}^{(\mathrm{b})} \\
\text { Diameter, cm (in.) } \\
\text { Length, cm (in.) }\end{array}$ & $\begin{array}{l}94 \\
0.93(0.3669) \\
1.52(0.60)\end{array}$ & $\begin{array}{l}95 \\
0.82(0.3225) \\
1.35(0.530)\end{array}$ & $\begin{array}{ll}94 & \\
0.96 & (0.3795) \\
1.52 & (0.60)\end{array}$ & $\begin{array}{l}95 \\
0.83(0.325) \\
0.99(0.390)\end{array}$ & $\begin{array}{l}94 \\
0.94(0.37) \\
1.78(0.70)\end{array}$ & $\begin{array}{ll}94 & \\
0.82 & (0.324) \\
0.95 & (0.375)\end{array}$ \\
\hline \multicolumn{7}{|l|}{ Guide Tubes: } \\
\hline $\begin{array}{l}\text { Number } \\
\text { Upper } 00, \mathrm{~cm} \text { (in.) } \\
\text { Wall Thickness, cm (in.) } \\
\text { Material }\end{array}$ & $\begin{array}{l}20 \\
1.38(0.544) \\
0.043(0.017) \\
\text { Zry-4 }\end{array}$ & $\begin{array}{l}24 \\
1.22(0.480) \\
0.041(0.016) \\
2 r y-4\end{array}$ & $\begin{array}{l}4 \\
2.83(1.115) \\
0.091(0.036) \\
\text { Zry-4 }\end{array}$ & $\begin{array}{l}4 \\
2.83(1.115) \\
0.091(0.036) \\
\text { Zry-4 }\end{array}$ & $\frac{16}{2--}$ & $\begin{array}{l}24 \\
1.18(0.465) \\
0.043(0.017) \\
\text { Zry-4 }\end{array}$ \\
\hline \multicolumn{7}{|l|}{ Instrument Tubes: } \\
\hline $\begin{array}{l}\text { Number } \\
\text { oo, cm (in.) } \\
\text { Wail Thickness, cm (in.) } \\
\text { Material }\end{array}$ & $\begin{array}{l}1 \\
1.38(0.544) \\
0.043(0.017) \\
2 r y-4\end{array}$ & $\begin{array}{l}1 \\
1.22(0.480) \\
0.041(0.016) \\
\operatorname{Zry}-4\end{array}$ & $\begin{array}{l}1 \\
2.38(1.115) \\
0.091(0.036) \\
\operatorname{Zry}-4\end{array}$ & $\begin{array}{l}1 \\
1.06(0.417) \\
0.068(0.027) \\
\text { Zry-4 }\end{array}$ & $\overline{1} \overline{\operatorname{Zry}-4}$ & $\begin{array}{l}1 \\
1.07(0.420) \\
0.038(0.015) \\
\text { 2ry-4 }\end{array}$ \\
\hline Tie Plate Material & 304 SS & 304 SS & 304 SS & 304 SS & 304 SS & 304 SS \\
\hline \multicolumn{7}{|l|}{ Spacers: } \\
\hline $\begin{array}{l}\text { Number } \\
\text { Material } \\
\text { Springs }\end{array}$ & $\begin{array}{l}7 \\
\text { Zry-4 } \\
\text { In } 718\end{array}$ & $\begin{array}{l}7 \\
\text { Zry-4 } \\
\text { In } 718\end{array}$ & $\begin{array}{l}9 \\
\text { Zry }-4 \\
\text { In } 625\end{array}$ & $\begin{array}{l}12 \\
\operatorname{Zry}-4 \\
\text { In } 625\end{array}$ & $\begin{array}{l}8 \\
\text { Zry-4 } \\
\text { In } 718\end{array}$ & $\begin{array}{l}8 \\
\text { Zry }-4 \\
\text { In } 718\end{array}$ \\
\hline \multicolumn{7}{|l|}{ Plenum Springs: } \\
\hline $\begin{array}{l}\text { Working Length, } \mathrm{cm} \text { (in.) } \\
\text { Material }\end{array}$ & $\begin{array}{l}17.3(6.80) \\
\text { In } 718\end{array}$ & $\begin{array}{l}17.0(6.70) \\
\text { In } 718\end{array}$ & $\begin{array}{l}21.8(8.60) \\
\text { In }\end{array}$ & $\begin{array}{l}16.4(6.48) \\
\text { In }\end{array}$ & $\overline{-}$ & $\begin{array}{l}-- \\
--\end{array}$ \\
\hline
\end{tabular}

(a) Zry-4 = Zircaloy-4; In = Inconel.

(b) $\mathrm{TD}=$ theoretical density. 
TABLE 13. Mechanical Design Parameters for BWR Fue 1

BWR Fuel Bund les

\begin{tabular}{|c|c|c|}
\hline Parameter & GE BWR/1-5 & GE BWR/6 \\
\hline Rod Array & $7 \times 7$ & $8 \times 8$ \\
\hline \multicolumn{3}{|l|}{ Fuel Bundles: } \\
\hline $\begin{array}{l}\text { Transverse Dimension, } \mathrm{cm} \text { (in.) } \\
\text { Assembly Weight, } \mathrm{kg}(1 \mathrm{~b}) \\
\text { Overall Bundle Length, } \mathrm{cm} \text { (in.) }\end{array}$ & $\begin{array}{l}14.0(5.518) \\
273(600) \\
435(171.2)\end{array}$ & $\begin{array}{l}14.0(5.518) \\
273(600) \\
435 \text { to } 453(171.2 \text { to } 178.5)\end{array}$ \\
\hline \multicolumn{3}{|l|}{ Fuel Rods: } \\
\hline $\begin{array}{l}\text { Number per Bundle } \\
\text { Rod Pitch, cm (in.) } \\
\text { Length, cm (in.) } \\
\text { Fueled Length, cm (in.) } \\
\text { OD, cm (in.) } \\
\text { Diametral Gap, cm (in.) } \\
\text { Clad Thickness, cm (in.) } \\
\text { Clad Material(a) }\end{array}$ & $\begin{array}{l}40 \\
1.87(0.738) \\
396(156.1) \\
366(144.0) \\
1.45(0.570) \\
0.033(0.013) \\
0.088(0.035) \\
\text { Zry-2 }\end{array}$ & $\begin{array}{l}55 \\
1.63(0.641) \\
396 \text { to } 415(156.1 \text { to } 163.5) \\
366 \text { to } 381(144.0 \text { to } 150.0) \\
1.25(0.493) \\
0.018(0.007) \\
0.088(0.035) \\
\text { Zry-2 }\end{array}$ \\
\hline
\end{tabular}

Fuel Pellets:

$$
\begin{aligned}
& \text { Density, \%TD(b) } \\
& \text { Diameter, cm (in.) } \\
& \text { Length, cm (in.) }
\end{aligned}
$$

Tie Plate Material

Spacers:

$$
\begin{aligned}
& \text { Number } \\
& \text { Material } \\
& \text { Springs }
\end{aligned}
$$

Plenum Springs:

Working Length, $\mathrm{cm}$ (in.)

Material

Compression Springs:

$$
\text { Working Length, cm (in.) }
$$

93

$1.24(0.487) \quad 1.06(0.416)$

$1.90(0.75) \quad 1.07(0.420)$

304 SS

304 SS

$\begin{array}{ll}7 & 7 \\ \text { Zry-4 } & \text { Zry-4 } \\ \text { In } & \text { In }\end{array}$

$26.9(10.6) \quad 26.9$ to $40.6(10.6$ to 16.0$)$

In

In

$2.39(0.94) \quad 2.13(0.84)$

In
In

(a) $Z$ ry-2 = Zircaloy-2; Zry-4 = Zircaloy-4; In = Incone 1 .

(b) $\mathrm{TO}=$ theoretical density. 
TABLE 14. Fuel Bundle Materials

\begin{tabular}{|c|c|c|c|}
\hline Component & Subcomp onent & Material & Alloy \\
\hline Fuel Pellets & & Uranium Dioxide & \\
\hline \multirow[t]{2}{*}{ Fuel Rods } & & Zircaloy & \multirow{2}{*}{$\begin{array}{l}\text { Zry-2 (BWR) } \\
\text { Zry-4 (PWR) } \\
304 ; 348 \mathrm{H}\end{array}$} \\
\hline & & Stainless Steel & \\
\hline Fuel Spacers & $\begin{array}{l}\text { Grid } \\
\text { Springs }\end{array}$ & $\begin{array}{l}\text { Stainless Steel } \\
\text { Inconel } \\
\text { Zircaloy } \\
\text { Inconel } \\
\text { Zircaloy }\end{array}$ & $\begin{array}{l}304 \\
718 \\
\text { Zry-4 } \\
718 ; 625 \\
\text { Zry-4 }\end{array}$ \\
\hline Upper Tie Plates & $\begin{array}{l}\text { Bail/Tie Plate } \\
\text { Bolts/Nuts } \\
\text { Springs }\end{array}$ & $\begin{array}{l}\text { Stainless Steel } \\
\text { Stainless Steel } \\
\text { Inconel } \\
\text { Inconel }\end{array}$ & $\begin{array}{l}304 \\
304 \\
600 \\
718 ; \times 750\end{array}$ \\
\hline Lower Tie Plates & Tie Plate/Nozzle & Stainless Steel & $304 ; C F-8$ \\
\hline Tie Rods & & $\begin{array}{l}\text { Zircaloy } \\
\text { Stainless Steel }\end{array}$ & $\begin{array}{l}\text { Zry-4 } \\
304\end{array}$ \\
\hline
\end{tabular}

environs. (39) For spent LWR fuel during interim pool storage, handling, and transport to terminal storage, the containment of additional volatile radionuclides is also required.

Not all fuel rods currently in interim pool storage contain volatile radionuclides. $(18,19,41,42)$ Failed fuel rods are all characterized by at least partial loss of containment integrity for volatile radionuclides. The loss of solid particulate radionuclides through a breach in the fuel rod cladding during a fuel duty cycle is generally acknowledged to be minor. Even though fuel rod failure statistics are suspect, the number of failed fuel rods within the current inventory of spent fuel in interim pool storage is undoubtedly low (estimated at less than 3\%) and probably has been decreasing because significant progress has been made in identifying and correcting the cause, source, and origin for some fuel rod failures. The current operating emphasis, however, has changed to a "once-through" duty cycle; and economics demand an extension of the duty cycle. In the absence of significant experience with 
extended duty cycles, it seems prudent to anticipate that fuel failures will continue to occur within the foreseeable future.

In failed fuel rods, most or all of the volatile radionuclides escape at about the time of the breach in the fuel rod cladding. In some cases, the mechanism(s) that caused the cladding breach may also have promoted release of the volatile radionuclides entrapped within the solid $\cup_{2}$ pellets and pellet fragments as well. It must be anticipated that in some, if not most, failed rods, some volatile radionuclides may remain entrapped within the solid $\mathrm{UO}_{2}$ fuel pellets. These entrapped volatile radionuclides may yet be released by further fragmentation of the $\mathrm{UO}_{2}$ or by solid-state thermal diffusion at intermediate and/or high temperature. Release by mechanical fragmentation can occur at virtually any temperature. Fragmentation by oxidation (i.e., $3 \mathrm{UO}_{2}+$ $\left.\mathrm{O}_{2} \rightarrow \mathrm{U}_{3} 0_{8}\right)$ may begin at temperatures as low as about $570 \mathrm{~K}\left(300^{\circ} \mathrm{C}\right) .(36,39,43,44)$ Based on these considerations, the failed fuel rods may yet release relatively minor amounts of volatile radionuclides during interim pool storage, handling, and transport to terminal storage. The release of solid particulate radionuclides from failed rods appears to be very unlikely during interim static pool storage. $(10,44)$ Limited release of solid particulate radionuclides may, however, occur during handling and transport if these operations aggravate existing damage.

Those fuel rods in interim pool storage with intact cladding containment will all contain "free" volatile radionucldes in varying amounts depending upon prior duty. Some fuel rods (primarily from PWRs) may contain an inert gas that was added during manufacture to improve heat transfer and/or mitigate cladding damage by creep collapse or pellet-cladding thermomechanical interaction phenomena during regular duty cycles. Technical specifications for LWR fuel currently limit the total combined fill gas and volatile fission products within the fuel rod to a duty pressure less than or equal to the normal reactor primary coolant system pressure. (45)

The cumulative damage that may accrue to the fuel rod cladding or the release of volatile fission products as a consequence of normal duty cycles is still a major uncertainty. (46) There has been no obvious fuel cladding degradation except from the most severe duty cycles and abnormal operating 
conditions. $(18,19,41,42,46-49)$ Very little of this fuel is in interim pool storage. Inasmuch as there have been a small but still significant number of fuel rod cladding failures from a small variety of causes and failure mechanisms, it must therefore also be assumed that there may be a small but significant number of fuel rods whose cladding has been damaged to some degree short of failure. Statistics for obvious fuel rod failures are still uncertain and probably unreliable; statistics on fuel rods whose cladding may have been damaged to some degree short of failure are simply nonexistent. Based on postirradiation examination ( $P I E$ ) of fuel rods removed from duty, there are known to be incipient cracks (i.e., cracks extending part way through the wall) starting from the inner surface (i.e., inside diameter) of the cladding on some Zircaloy-clad fuel rods. (49) These fuel rods are suspected of having become susceptible to SCC by fission products (e.g., iodine, cadmium) and/or slow strain rate embrittlement (SSRE) as a consequence of a power transient or other duty condition. $(47,48)$ Considering the prerequisites $(47)$ for SCC (fission product) or SSRE, it seems unlikely that they may again become susceptible and fail by either a SCC or SSRE mechanism during interim pool storage. There may, however, be some likelihood for aggravation of prior damage during handling and transport to terminal storage.

In summary, the greatest potential concern is expected to result from the loss of cladding integrity and the associated loss of containment of the free volatile radionuclides in individual fuel rods. This potential hazard appears to be: greatest for those fuel rods that sustained some damage short of cladding failure during prior duty, intermediate (in general) for sound fuel rods, and minimal (if temperatures are controlled) for already-failed rods. The loss of solid particulate radionuclides seems unlikely, except in cases of severe and extensive oxidation $(a)$ and/or structural damage to the fuel rod cladding.

(a) Crud (scale) buildup can cause cladding to overheat peak power locations and result in accelerated oxidation and hydriding, which can eventually lead to fuel rod failures. Fuel rod bowing can also iead to accelerated corrosion. 
The known or suspected degradation mechanisms (general corrosion, SCC, oxidation, hydriding, creep and stress rupture, SSRE, etc.) apparently are either not activated or the rates are insignificant at normal interim pool storage conditions. $(10,44)$ By the same logic, however, those mechanisms that could mitigate the adverse effects of irradiation damage sustained in prior duty (thermal recovery, annealing, etc.) are also either not activated or the rates are inconsequential at interim pool storage temperatures. There are few data of statistical significance relevant to interim pool storage. Interim pool storage experience overall, however, is conspicuous by the absence of obvious fuel rod/cladding degradation and/or failures. With the exception of some decay in radioactivity and reduction in self-heating rates, LWR fuel rods and bundles may generally be considered to be in about the same overall mechanical condition as when they were placed in interim pool storage.

On the assumption that little or no degradation of consequence has occurred during interim pool storage, the principal concern relative to threshold limits (especially for the fuel rod cladding) is the potential for damage and/or the aggravation of prior damage as a consequence of handling and transport to terminal storage.

\subsection{LIMIT CONSIDERATIONS}

In general, engineering limits are designed and developed to maximize the probability that the functional integrity of a component is insured throughout its useful life. As used for component design and operation, the functional or allowable limits are generally developed from some combination of:

A. intrinsic material indices consisting of one or more of the following:

1) elastic, shear, and/or tangent modulus

2) yield, ultimate, and/or shear strength

3) elongation and/or reduction in area

4) impact strength

5) fracture toughness and/or crack arrest

6) creep and/or stress rupture strength 
7) fatigue strength and/or endurance limit

8) susceptibility to SSRE as evidenced in slow bend or static fatigue tests

9) susceptibility to general cracking and/or SCC in hostile environments

10) transition and/or nil-ductility temperature

11) SEAF (area under stress versus strain diagram)

B. extrinsic duty parameters involving one or more of the following:

1) temperature

2) load and/or displacement

3) environment

4) time in duty and/or duty cycle chronology

5) rate and magnitude of changes in duty cycles

6) component geometry

C. cumulative damage function based on one or more of the following rules:

1) life-fraction rules: $(50,51)$

a) Robinson life rule:

$$
\sum_{1}^{i}\left(t_{i} / t_{i f}\right)=1
$$

b) Oding-Burdsby life rule

$$
\sum_{1}^{i}\left(t_{i} / t_{i f}\right)^{m}=1
$$

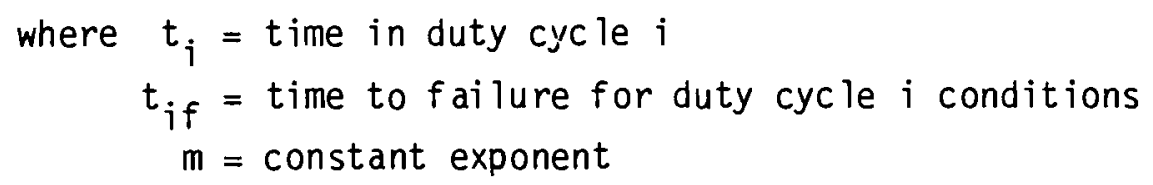


2) strain-fraction rules: $(50,51)$

a) Lieberman strain rule:

$$
\sum_{1}^{i}\left(\varepsilon_{i} / \varepsilon_{i f}\right)=1
$$

where $\varepsilon_{j}=$ strain accumulated in duty cycle $i$ $\varepsilon_{i f}=$ strain to failure for duty cycle $i$ conditions

3) modified life-strain fraction rules: (50-52)

a) Freeman-Voorhies mixed rule:

$$
\sum_{i}^{i}\left[\sqrt{t_{i} / t_{i f}} \times \sqrt{\varepsilon_{i} / \varepsilon_{i f}}\right]=1
$$

b) Abo El Ata-Finnie mixed rule:

$$
k \times \sum_{1}^{i}\left(t_{i} / t_{i f}\right)+(1-k) \times \sum_{1}^{i}\left(\varepsilon_{i} / \varepsilon_{i f}\right)=1
$$

where $k=$ constant coefficient

4) energy absorption fraction rule: $(53,54)$

$$
\sum_{1}^{i}\left[\left(S E_{i}+E V_{i}\right) / S E A F_{i f}\right]=1
$$

where $\quad S E_{i}=$ strain energy accumulated in duty cycle $i$

$E V_{i}=$ environmental energy effect during duty cycle $i$

SEAF $_{\text {if }}=$ strain energy absorption to failure for duty cycle $i$ conditions 
D. failure criteria consisting of one or more of the following:

1) Tresca maximum shear stress criterion (55)

2) Henky-Von Mises distortion energy theory

3) Coffin-Manson rule for fatigue (56)

4) Monkman-Grant rule for creep and stress rupture (57)

5) linear elastic fracture mechanics (LEFM) theory for brittle failure ${ }^{(58)}$

6) Strain energy density criterion for crack initiation $(59,60)$

7) strain rate-dependent and environment-dependent SEAF criteria. $(47,53)$

In normal engineering practice, material indices, duty parameters, cumulative damage functions, and failure criteria, such as those listed above, are combined for specific applications to identify and define design and operating limits to minimize the risk of functional failure via component collapse and/or material degradation. Where it is necessary to insure the protection of operating personnel, the public, and/or the environs, these limits are generally embodied in code standards (ASME, ANSI, etc.) and/or government regulatory codes (Title 10-Code of Federal Regulations).

Current engineering practice, even as required for code applications, pays little or no attention to the mechanics of response of already-degraded component materials and/or already-damaged assemblies or structures. There is current but 1 imited use of cumulative damage concepts for minimizing the risk of failure from a succession of some specific and anticipated loadings (fatigue followed by and/or interspersed with creep). Until recently there were no cumulative damage functions for combining the effects of more than a single loading mode. Life-fraction (C.1) and strain-fraction (C.2) rules are characteristic of this current loading mode limitation. Nevertheless, these two cumulative damage rules are the most prevalently used. The modified lifestrain fraction rule (C.3) is an example of recent at tempts to account for creep and cyclic loading mode effects as they combine to cause failure by the commonly known phenomenon of low-cycle fatigue. Energy concepts, based on 
strain and/or environmental effects, are beginning to receive serious attention for both cumulative damage functions (C.4) and failure criteria (D.6, D.7). As a cumulative damage function, 0stergren ${ }^{(54)}$ applied strain energy absorption concepts to strain-controlled, low-cycle fatigue at elevated temperature with significant success. The strain rate-dependent and environmentdependent SEAF concept, as applied to interstitial-dislocation interaction(a) sensitive materials, appears to offer considerable potential as a cumulative damage rule (C.4) and a failure criterion (D.7).

Of the listed cumulative damage rules, SEAF alone appears to offer an approach for cumulative damage considerations that include environmental effects in addition to temperature and creep, fatigue, thermal, mechanical, and/or impact loading modes. Although SEAF appears to offer added capabilities relative to the list of cumulative damage rules and failure criteria, its use as a cumulative damage rule ${ }^{(54)}$ or a failure criterion $(47,53)$ is limited and untested for the impact mode of loading. Considerable experimental research is needed to fully develop the strain rate-dependent and environmentdependent SEAF concept as a cumulative damage rule and a failure criterion.

PIE results show ${ }^{(48)}$ that some fuel rods, which are nearest neighbors to those fuel rods that failed as a consequence of prior duty, also sustained part-through-wall cracking without the loss of containment integrity for the free volatile radionuclides within the fuel rod. As yet there is no specific cumulative damage rule that can provide reliable estimates as to the growth of these existing cracks that may occur during subsequent handing and transport to terminal storage without prior knowledge of the pre-existing crack size and geometry. Experimental crack growth studies show that stresses and presumably strains, which are parallel to the growth direction of a crack, have little if any influence on subsequent growth and propagation. In already-damaged fuel rods, crack orientation is most likely to be parallel to the fuel rod axis. The expected handling stresses and/or strains are therefore likely to be parallel to any pre-existing crack. Whether the fuel bundle is transported in the horizontal or vertical position, essentially all of the expected vibrational displacements in individual fuel rods will be nomal to the fuel rod

(a) This is sometimes referred to as dynamic strain aging. 
axis. It is therefore unlikely that there will be any significant axial or radial growth of any pre-existing crack unless the vibrational displacement amplitudes are large enough to cause significant cyclical ovalization of cladding. If the fuel pellets (even though they may be severely cracked) tend to retain their solidity and cylindrical geometry, the potential for and extent of cladding ovalization will both be limited. It must, however, be recognized that this postulated behavior for al ready-damaged fuel rods has not yet been confirmed by experiments.

A11 PIE results from al ready-damaged fuel rods suggest that the axial cracking, which is generally believed to be associated with PCI, originated within the circumferential ridge that generally develops in the cladding at pellet-pellet interfaces. As yet, there are no reported observations of circumferential cracking within these ridges. These ridges, however, are the most likely regions in already-damaged fuel rods to be susceptible to further damage from handling and transport operations.

Considering all of the foregoing, the mechanisms by which sound and/or al ready-damaged fuel rods may degrade and fail can be identified. The degradation and failure mechanisms that may cause a loss of fuel rod containment integrity for both free volatile and/or nonvolatile solid radionuclides are tentatively identified as follows:

- mechanical overloading and/or impact due to accidental mishandling

- fatigue due to induced vibrations during transport

- impacts arising from a transport accident

- overheating that causes:

a) oxidation and disintegration of solid $\mathrm{UO}_{2}$ pellets and pellet fragments to $\mathrm{U}_{3} \mathrm{O}_{8}$ powder (applies only to al ready-failed fuel rods)

b) volatilization by oxidation and/or the release of volatile fission products retained within the solid $\mathrm{UO}_{2}$ pellets or pellet fragments at normal interim pool storage temperatures (applies only to al ready-failed fuel rods) 
c) resensitization of Zircaloy cladding to SCC embrittlement ${ }^{(a)}$ by internally contained fission products (iodine, cadmium, etc.)

d) oxidation and embrittlement of Zircaloy cladding

e) creep and stress rupture

f) corrosion (general, crevice, etc.)

g) general and/or local hydriding.

In BWR fuel bundles, there are eight peripheral tie rods that also function as load-carrying components. In most PWR bundles, the control element guide tubes also function as key structural and load-carrying components. In at least one PWR fuel bundle design (Palisades), eight peripheral Zircaloy bars are used as control element guides and as key structural and load-carrying components. In all cases, these key components carry the entire weight of the fuel bundle and, as a consequence, will bear the acceleration loads that may normally be expected in any handling operation.

\subsubsection{Interim Pool Storage Limits}

Considering the material indices (cladding and fuel), duty parameters, cumulative damage, and failure criteria, the degradation and failure mechanisms that appear to be of significance relative to interim pool storage are those that are temperature dependent. Fuel rods and bundles are designed to withstand duty temperatures for nomal and limited abnomal operating conditions that are significantly greater than those expected during interim pool storage. For LWR fuels, the current duty period is 4 to $5 \mathrm{yr}$. For projected fuel burnups, the duty period may be 5 to $6 \mathrm{yr}$. Material indices and reaction kinetics considerations suggest that both sound and al ready-damaged fuel rods can safely withstand pool storage conditions for substantially longer periods. Both sound and al ready-damaged fuel rods have been held in interim pool storage for extended periods without obvious and significant degradation or failure. $(10,44)$ This successful experience has included some mishandling incidents (see

(a) There is no distinction made between SCC and liquid/vapor metal embritt lement. 
Section 3.2). Based on these considerations, it appears that the risk of unacceptable degradation and/or fuel rod failures by any of the listed mechanisms is insignificant for current LWR fuel designs and duty burnups in existing storage pools. The suggested limits for interim pool storage are:

- pool temperature - $\leq 270 \mathrm{~K}\left(100^{\circ} \mathrm{C}\right)$

- cladding temperature $-\leq 320 \mathrm{~K}\left(150^{\circ} \mathrm{C}\right)$

- duration - to $20 \mathrm{yr}$

- fuel $\left(\mathrm{UO}_{2}\right)$ temperature $-\leq 570 \mathrm{~K}\left(300^{\circ} \mathrm{C}\right)$. (a)

There are evolutionary fuel designs (e.g., prepressurization) and/or potential changes in duty (extended burnup, load/demand following operation, etc.) that are not represented to any significant extent in the inventory of spent LWR fuel in current pool storage experience. Prepressurization of fuel rods is already in widespread use for PWR fuels, which coincidentally also have the thinnest cladding of all LWR fuels. Substantial research and development is under way to extend the fuel burnup duty cycle and develop new fuel rod designs that can tolerate load/demand following duty. Substantial pressures within fuel rods could develop as a consequence of prepressurization and extended burnup under duty conditions that enhance the release of volatile radionuclides from the solid $\mathrm{UO}_{2}$ pellets and pellet fragments. Load/demand following duty will substantially increase the cumulative cladding damage from low-cycle thermal fatigue and volatile radionuclide release. These considerations suggest that creep and stress rupture and low-cycle thermal fatigue could become considerations of importance in developing future interim pooi storage limits. Although there are relatively few fuel bundles with prepressurized rods currently in interim pool storage, there are many that are rapidly approaching the end of their normal duty cycles. It is therefore timely to undertake the appropriate research and development to evaluate prepressurization effects vis-a-vis interim pool storage limits.

(a) This limit applies only to failed fuel rods wherein the pool storage water may gain access to the $\mathrm{UO}_{2}$ and is intended to minimize the risk of oxidation of the particulate $\mathrm{UO}_{2}$ to $\mathrm{U}_{3} \mathrm{O}_{8}$ or intermediate oxidation states that may produce fine powders or aerosols. 


\subsubsection{Temperature Threshold Effects for Fuel in Helium or Air}

Temperature is a very important threshold limit affecting the degradation and failure of spent fuel not only because of its effect on the temperaturedependent properties of the materials comprising the fuel rods but also because it directly controls the level of internal pressure (the origin of primary cladding stresses) and the activity of intracladding radionuclides. Consequently, the temperature of fuel in helium or air must be controlled by adequate cooling. Current recommended temperature threshold limits for nonbreached and breached fuel rods for different failure modes are presented in Tables 15 and 16, respectively. In general, PWR spent fuel rods have lower temperature threshold limits than BWR spent fuel rods due to the higher internal pressure associated with PWR fuel rods. Consequently, it will be assumed that both fuel types have the same threshold limits to avoid classifying facilities or repositories as suited for specific fuel types; the threshold limits for PWR fuel rods will be used.

Threshold temperature limits can be higher if credit is taken for the dependence of the decay heat as radionuclides transmute and if an influx of heat from newly deposited fuel rods into regions of storage containing fuel rods that have lower levels of decay heat is prevented. In other words, fue 1 rods of different ages should be thermally shielded from each other. The temperature advantage of thermal shielding $c$ an be as high as 60K for stress rupture (see Table 15).

Threshold limits associated with pressure-driven stresses assume simple pressure loading and should be altered if other significant loading modes are introduced. Furthermore, the pressure-related limits such as stress rupture and mechanical overload could be increased if the internal pressure in the fuel rods were vented prior to handling, transportation, and storage. Two systems for puncturing irradiated fuel rods in a spent fuel storage pool and collecting the fission gases and other gases have been developed and successfully demonstrated. (62) However, only one of those systems has the means for mechanically resealing a rod after it has been punctured. The seal is capable of withstanding a fuel rod internal pressure of at least $10.3 \mathrm{MPa}$ (1500 psi). 
TABLE 15. Recommended Cladding Temperature Threshold Limits for Nonbreached Fue? Rods

\begin{tabular}{|c|c|c|c|}
\hline \multirow[b]{2}{*}{ Failure Mode } & \multicolumn{2}{|c|}{$\begin{array}{c}\text { Threshold Temperature Limits, } \\
\mathrm{K}\left({ }^{\circ} \mathrm{C}\right)\end{array}$} & \multirow[b]{2}{*}{ Reference } \\
\hline & In Helium & In Air & \\
\hline Stress Rupture & $\begin{array}{l}650(380)(a) \\
590(320)(b) \\
630(360)\end{array}$ & $\begin{array}{l}650(380)(a) \\
590(320)(b) \\
630(360)\end{array}$ & $\begin{array}{l}43 \\
43 \\
61\end{array}$ \\
\hline $\begin{array}{l}\text { Mechanical Overload } \\
\text { (short term) }\end{array}$ & $670(396)$ & $670(396)$ & 43 \\
\hline Cladding Corrosion & $>670 \quad(>400)$ & $570(300)(c)$ & 36 \\
\hline
\end{tabular}

(a) Initial temperature followed by reduced decay heat.

(b) I sothermal conditions.

(c) Based on loss of $10 \%$ of cladding thickness in $100 \mathrm{yr}$.

TABLE 16. Recommended $\mathrm{Cl}$ adding and Fuel Temperature Threshold Limits for Breached Fuel Rods

\begin{tabular}{|c|c|c|c|}
\hline Failure Mode & $\frac{\text { Threshold Temperat }}{\text { In Helium }}$ & $\frac{\text { Limits, } K\left({ }^{\circ} \mathrm{C}\right)}{\operatorname{In} A i r}$ & Reference \\
\hline Stress Rupture & NA(a) (low pressure) & NA (low pressure) & \\
\hline Mechanical Overload & NA (low pressure) & NA (low pressure) & \\
\hline $\begin{array}{l}\text { Stress Corrosion } \\
\text { Cracking }\end{array}$ & NA (low pressure) & NA (low pressure) & \\
\hline Cladding Corrosion & $>670(>400)$ & $570(300)(b)$ & 36 \\
\hline $\mathrm{UO}_{2}$ oxidation & $570(300)$ & $\begin{array}{l}470(200)(c) \\
570(300)(d)\end{array}$ & $\begin{array}{l}36 \\
36\end{array}$ \\
\hline
\end{tabular}

\footnotetext{
(a) Not applicable.

(b) Based on loss of $10 \%$ of cladding thickness in $100 \mathrm{yr}$.

(c) Based on oxidation of $\mathrm{UO}_{2}$ to $\mathrm{U}_{3} \mathrm{O}_{8}$ in 46 to $96 \mathrm{yr}$.

(d) Based on oxidation of $\mathrm{UO}_{2}$ to $\mathrm{U}_{3} \mathrm{O}_{3}$ in 9 to 18 days.
} 
Technology is also at hand for venting spent fuel rods by drilling them with a laser and subsequently sealing the hole by welding, which is done by defocusing the same laser.

The threshold temperature limits associated with stress rupture, SCC, mechanical overload, fuel rod cladding corrosion, and $\mathrm{UO}_{2}$ oxidation are discussed below.

Stress Rupture

Threshold temperature limits for stress rupture are based on the presence of irradiation hardening throughout the storage period. Irradiation hardening in Zircaloy is partially attributed to the preservation of Seegar Zones, which form during irradiation. Seegar Zones are very unstable at temperatures above 670K $\left(400^{\circ} \mathrm{C}\right)$; consequently, short temperature excursions exceeding $670 \mathrm{~K}$, which might occur at any point during the period between discharge of fuel bundles from the reactor to final disposition of fuel rods or bundles in a storage facility, could likely eliminate the irradiation hardening associated with Seegar Zones. A ten-fold decrease in rupture life due to removal of irradiation hardening would result in a $20 \mathrm{~K}$ reduction in the threshold temperature limits for stress rupture listed in Table 15. It would be advisable to conduct some stress rupture experiments on spent fuel cladding to establish the behavior. The present limits are based on stress rupture results from tests on unirradiated Zircaloy. It is anticipated that the uncertainty associated with this extrapolation is about $\pm 50 \mathrm{~K}$.

There is a trend to extend the burnup of fuel rods to achieve greater utilization of uranium. This trend will increase the end-of-life internal pressures in fuel rods toward the maximum employed in the temperature limit analyses $(43)$ and will reduce the conservatism in stress rupture by $\sim 44 \mathrm{~K}$. (a) Stress Corrosion Cracking (SCC)

The threshold temperature limit for SCC was proposed as $620 \mathrm{~K}\left(350^{\circ} \mathrm{C}\right)$ for nondegraded cladding with flaw sizes representative of as-fabricated cladding and $560 \mathrm{~K}\left(290^{\circ} \mathrm{C}\right)$ for degraded cladding with flaw sizes characterized with

(a) From the original $378 \mathrm{~K}\left(105^{\circ} \mathrm{C}\right)$ down to $334 \mathrm{~K}\left(61^{\circ} \mathrm{C}\right)$. 
depths of about $50 \%$ of the wall thickness. (43) It was recommended that these limits not be restrictive because of the extremely limited experimental evidence to verify the evaluation of the threshold stress intensity, K $\mathrm{KSCC}_{\text {, }}$ for SCC (i.e., the lowest value of stress intensity at which iodine-induced slow crack growth in the Zircaloy cladding can occur under plane strain, linear elastic conditions). (63) A test program would be highly desirable to verify these estimates or to provide some valid estimates. Inadequate mechanistic understanding of and a very limited data base on SCC dictate against placing severe restraints on spent fuel storage concept selection or design scoping studies. Further experimental work is needed to verify potential SCC effects. Present estimates should be viewed as precautions that maximum allowable temperatures could be lower than $650 \mathrm{~K}\left(380^{\circ} \mathrm{C}\right)$ if SCC effects are verified.

\section{Mechanical Overload}

The threshold limit for a mechanical overload was estimated at $670 \mathrm{~K}$ $\left(396^{\circ} \mathrm{C}\right.$ ) based on short-term tensile properties. (43) Mechanical overload is limited to a short time period and is derived from the internal pressure; hence, it would not apply to a breached fuel rod from which the pressure had been vented.

Fue 1 Rod Cladding Corrosion

A temperature limit of $570 \mathrm{~K}\left(300^{\circ} \mathrm{C}\right)$ was proposed for corrosion of Zircaloy cladding in air or steam that would amount to $10 \%$ of the wall thickness in $100 \mathrm{yr} .{ }^{(36)}$ Although the limit could be raised slightly if a larger percentage of the wall were allowed to be corroded, it would be questionable to permit cladding corrosion much beyond $10 \%$ for degraded cladding. The temperature limits are considerably higher if the cladding is in helium.

$\underline{\mathrm{UO}}_{2}$ Oxidation

$\mathrm{UO}_{2}$ oxidation can occur in breached fuel rods if the fue 1 is exposed to air or water. $\mathrm{UO}_{2}$ oxidizes to $\mathrm{U}_{3} \mathrm{O}_{8}$ in 46 to $96 \mathrm{yr}$ at $470 \mathrm{~K}\left(200^{\circ} \mathrm{C}\right)$ and it is predicted that $\mathrm{UO}_{2}$ would be converted to $\mathrm{U}_{3} \mathrm{O}_{8}$ in 9 to 18 days at $570 \mathrm{~K}$ $\left(300^{\circ} \mathrm{C}\right) .(36)$ The $470 \mathrm{~K}\left(200^{\circ} \mathrm{C}\right)$ temperature limit for breached fuel rods in air is the lowest and limiting value. 


\subsubsection{Threshold Limits for Strain}

Strain limits are not recommended because of the difficulties associated with measuring the levels of strain in individual fuel rods.

\subsubsection{Threshold Limits for Shock and Vibration}

The exposure of spent fuel to shock and vibration occurs primarily during disassembly of fuel bundles, handling of fuel rods and bundles, packaging of fuel rods, transporting of fuel rods and bundles, and seismic events. Fatigue is not expected to be a significant failure mode because the number of significant load cycles is too small to induce fatigue failures. The primary source of failure has been attributed to and will continue to result from short-time over loads due to mishaps during handling, transportation, and packaging. Results from the analysis of the structural response of spent fuel structural integrity after shock loadings indicate that accelerations up to approximately $30 \mathrm{~m} / \mathrm{s}^{2}$ (three times the gravitational constant) lateral loadings (2) or approximately $70 \mathrm{~m} / \mathrm{s}^{2}$ (seven times the gravitational constant) axial loadings are tolerable without inducing further degradation of fuel rods, assuming that fuel rods or bundles do not contact sharp objects.

A container holding a close-packed array of spent fuel rods from disassembled fuel bundles may be structurally more stable than a fuel bunde prior to disassembly. Consequently, threshold limits for shock and vibration are not expected to be reduced for containers with individual spent fuel rods. One feature that may need to be considered is wear due to friction and fretting from rod-to-rod contact.

It is recommended that spent fuel bundles or contdiners of spent fuel rods should be monitored with accelerometers to document the maximum shock loadings. Bundles or containers showing excessively high levels of shock (e.g., accelerations greater than approximately $30 \mathrm{~m} / \mathrm{s}^{2}$ for lateral loadings or approximately $70 \mathrm{~m} / \mathrm{s}^{2}$ for axial loadings) should be subsequently inspected for damage or degradation.

\subsubsection{Handling Limits}

Spent LWR fuel bundles are handled in preparation for shipment from the interim pool storage facilities to the terminal storage facility. As 
suggested in previous discussions, it is unlikely that spent LWR fuel will sustain any significant damage or aggravation of existing damage from prior duty during interim pool storage, with the exception of an interim storage handling accident. As yet, there is no experience of statistical significance as to the effects of transport on the condition of spent LWR fuel bundles upon arrival at the terminal storage facility. Based on these considerations, the limits and/or precautions required for handling at the terminal storage facility could be significantly different from those for handling at interim pool storage facilities.

In each of the LWR fuel designs (for both BWRs and PWRs) there are relatively few key components that support the weight of the fuel bunde and other normal loadings during handling. In BWR fuel bundles, these key components are the:

- lifting bail

- upper and lower tie plates

- eight peripherally spaced fuel rods that connect the upper and lower tie plates (these fuel rods are generally referred to as tie rods).

In PWR fuel bundles, the key components are the:

- inlet and outlet nozzle plates

- control element guide tubes. (In a few designs, the control element guide tubes are replaced by eight peripherally spaced control assembly guide bars.)

All LWR fuel assemblies are designed to allow for the functional loss in load-carrying capability of a few tie rods or guide tubes or bars. Any priorduty damage of major significance should have been evident during in-core handling or at final discharge of the spent fuel bundle. There are, however, PWR fuel bundles currently in service that sustained serious fretting/wear of the control element guide tubes. It is currently uncertain whether proposed remedies will adequately mitigate this fretting/wear. It therefore seems prudent to anticipate that, in cases of this nature, special handing equipment and/or procedures may be required. 
As described in Section 3.2, some slightly abnormal and abnormal handling incidents have occurred during in-core and/or subsequent interim pool storage handling. Very few fuel bundles have been damaged as a result of handling operations. The information relating to handling incidents is sparse and does not appear to provide an adequate statistical basis to assess the likelihood for a major release of volatile and/or solid radionuclides.

Few, if any, spent LWR fuel bundles have undergone extended-burnup $(\sim 40.0$ to $60.0 \mathrm{MWd} / \mathrm{kgJ}$ ) duty cycles. As the duty cycle is extended, the frangibility of neutron-irradiated, load-carrying components can be expected to increase. Currently there are very few pertinent postirradiation data available to assess the effects of low and intermediate fuel burnup duty cycles (less than $1 x$ $10^{22} \mathrm{nvt}$ ), and pertinent postirradiation data to assess the effects of extended-burnup duty cycles (more than $1 \times 10^{22}$ nvt) simply do not exist. Fortunately, however, it is unlikely that there will be any spent LWR fuel bundles from extended-burnup duty cycles within the next few years. Spent high-burnup experimental breeder reactor fuel can be expected to be discharged and placed in interim storage at least as soon and perhaps sooner than extended-burnup LWR fuels.

Based on the foregoing considerations, it is not prudent to suggest handling limits for spent LWR fuel bundles other than the low- to intermediateburnup fuel bundles now in interim pool storage. For these bundles, the existing 1 imits and/or procedures are as good as any that may be developed with current existing data. These limits and/or procedures may not be sufficiently conservative for handing at the terminal storage facility because of the potential damage or aggravation of prior-duty damage that may occur during transport. For sound fuel, an analys is of the potential effects of vibration during transport is the minimum requirement. Experimental data are required for impact loads during transport and for fuel already damaged in prior duty.

\subsubsection{Transport Limits}

As noted in the previous sections, there is experience of statistical significance relative to spent LWR fuel bundle interim storage and handing within the reactor and pool storage facilities. Cranes and other handing equipment 
are generally "trip" limited to minimize the risk of overloading during handling. There is limited experience $(a)$ of statistical significance regarding transport of spent LWR fuel to and subsequent handling at either reprocessing and/or terminal storage facilities. This limited experience includes at least some LWR fuel bundles that have sustained damage and/or failure during prior duty. In general, this limited transport and handling experience apparently did not involve any uncontrolled release of significant amounts of volatile, aerosol, or solid particulate radionuclides. Based on this limited transport and handling experience, it seems reasonable to suggest that the 1 imits and procedures currently employed can continue to be used on at least an interim basis.

Because of the absence of spent LWR fuel bundle transport experience, analytical and exploratory experiments have been performed in an attempt to identify and evaluate the shock and vibration environment that spent LWR fuel bundles may encounter during transport by truck and/or rail to terminal storage. $(60,64-68)$ Within these efforts, shock loadings and system responses that accompany a truck or rail accident have been evaluated experimentally. $(60,64-67)$ Results from some of the analyses $(67)(b)$ suggest that:

- The induced peak cyclic cladding stresses are modest $\left(<1.27 \mathrm{~kg} / \mathrm{mm}^{2}\right.$ or <18 ksi for Zircaloy-clad fuel).

- The number of peak cyclic loadings is small (the number of cycles is estimated to be less than 5000). Based on computed stress intensification and the fracture toughness of the cladding, it was concluded that there is little likelihood for failure of either sound or already-damaged Zircaloy-clad fuel rods during transport to terminal storage.

Upon examination, however, there appear to be several uncertainties in these analyses. (b) First and foremost, it is uncertain whether the material property data used are fully characteristic of spent LWR fuel cladding

(a) A total of 1615 LWR fuel bundles have been transported to a domestic reprocessing facility. A total of 1952 LWR fuel bundles have been trans-
ported to domestic independent spent fuel storage installations. $(10,15,16)$

(b) These were analytically based studies (not experimentally based). 
material relative to thermomechanical and/or thermochemical interaction effects from prior duty. In general, postirradiation materials testing is not often concerned with prior-duty effects other than fast neutron fluence and to a lesser extent irradiation temperature. Zircaloy, as used for LWR fuel rod cladding, is strongly sensitive to interstitial-dislocation interaction effects within the duty temperature range. $(47,53)$ As yet, there is considerable uncertainty as to the interstitial-dislocation interaction enhancement by fast neutron irradiation. There have been no systematic experiments on either irradiated or unirradiated fuel rod cladding to identify and quantify the effects of this interaction on fracture toughness, crack growth rates, fatigue endurance limits, and either time-dependent or time-independent SEAF material indices.

The studies cited did not include evaluation of prior-duty effects via one or more life-fraction rule. In view of the rather long interim storage periods, it is uncertain whether prior duty must be considered in defining transport and subsequent handling limits for both sound and prior duty-damaged spent fuel.

With spent LWR fuel assemblies that are shipped dry or wet, there must be adequate concern for and consideration of fuel and fuel rod cladding temperatures that may occur in either case. In such cases, the considerations for sound fuel are different from those for prior duty-damaged fuel even though the fuel and fuel rod cladding temperatures may be similar. All sound fuel rods contain some free volatile radionuclides. As the fuel and cladding temperatures rise, the internal gas pressure loading described by the gas law (PV nRT) may become significant; and when superimposed on the computed peak cyclic stresses ( $18 \mathrm{ksi}$ for Zircaloy-clad fuel rods), there may be an increased risk of cladding failure via mechanical (thermal expansion) overload, thermally activated creep, and/or high-stress, low-cycle fatigue. This risk is enhanced in prepressurized fuel rods and extended-burnup cycle fuels. Furthermore, in about the 470 to $620 \mathrm{~K}\left(200\right.$ to $\left.350^{\circ} \mathrm{C}\right)$ temperature range, zircaloy fuel rod cladding is most susceptible to interstitial-dislocation interaction, SSRE, and fission product (iodine, cadmium) SCC. At higher fuel rod cladding temperatures, little is known about thermochemical fuel and cladding interaction(s), kinetics, and consequences. 
For prior duty-damaged fuel, which contains no free volatile radionuclides, the potential consequences may not be quite as great as when volatile radionuclides are present. If fuel temperatures exceed about 570 to $620 \mathrm{~K}$ ( 300 to $\left.350^{\circ} \mathrm{C}\right)$ for significant periods or about $670 \mathrm{~K}\left(400^{\circ} \mathrm{C}\right)$ for short periods, there may be significant thermal decomposition of the solid $\mathrm{UO}_{2}$ to powdery $\mathrm{U}_{3} \mathrm{O}_{8}$, accompanied by the release of retained volatile radionuclides. Vibratory motion of the fuel rods during transport $c$ an be expected to cause the release of particulate radionuclides to the shipping cask interior. The higher temperature thermochemical fuel and cladding interaction considerations also apply to prior duty-damaged fuel.

It does not now appear feasible to at tempt to set any practical limit for transport and subsequent handling without further experimentation and/or analytical evaluations. As a minimum, limit consideration must include time, temperature, vibration, and shock for transport in dry casks and/or casks without forced cooling. It is anticipated that time and temperature effects may be practically controlled via interim storage in a pool for a minimum period until the heat-generating capacity of the spent LWR fuel has decreased to a level acceptable for transport.

\subsubsection{Summary}

The potential hazard to facility operating personnel, the public, and/or the environs during interim storage, handling, and transport to terminal storage (and/or reprocessing) facilities is estimated to occur through:

- the loss of fuel rod cladding containment of the free volatile radionuclides within the spent fuel rods by mechanical and/or thermochemical PCI; this possibility appears to be enhanced for prepressurized and extended-burnup cycle fuel

- the thermal degradation of solid $\mathrm{UO}_{2}$ in fuel rods damaged during prior duty by oxidation to powdery $\mathrm{U}_{3} \mathrm{O}_{8}$ and the attendant further release of smaller quantities of volatile and/or particulate radionuclides.

In terms of extrinsic duty parameters, temperature appears to be of firstorder importance, particularly with respect to interim storage and transport 
in dry and/or noncooled shipping casks. Preliminary analytical studies suggest that loads and/or displacements expected in handling and transport are of second-order or minor importance. However, as more prepressurized and/or extended-burnup cycle fuel comes into the spent fuel systems, these extrinsic duty parameters may assume greater importance.

The intrinsic material indices of greatest importance appear to be:

- SEAF

- SSRE

- fracture toughness

- fatigue strength

- susceptibility to thermochemical PCI.

SEAF appears to be the most pertinent of the material indices because it effectively combines not only the yield and ductility indices but also the sensitivity of the LWR fuel rod cladding to temperature and/or irradiationenhanced interstitial-dislocation interactions as manifested in strain rate and/or environmental effects. SEAF is also expected to function as one of the more practical life-fraction rules in assessing effects of duty cycle chronology.

Preliminary limits for interim storage, handling, and normal transport $(a)$ to terminal storage (or reprocessing) facilities are suggested as follows:

- interim storage in water

a) fuel-to-cladding interface temperatures of $\leq 620 \mathrm{~K}\left(350^{\circ} \mathrm{C}\right)$ for nonfailed fuel rods

b) exposed fuel surface temperature of $\leq 570 \mathrm{~K}\left(300^{\circ} \mathrm{C}\right)$ for failed fue 1 rods

- handling - current load/trip limits in force at the reactor and at interim storage pool facilities; it is presumed that the load/trip setting at all LWR facilities (for example, for cranes and other handling equipment) is 1.5 times the fuel bundle weight

- normal transport

(a) Higher limits would be allowable for transport accidents. 
a) fue l-to-cladding interf ace temperatures of $\leq 620 \mathrm{~K}\left(350^{\circ} \mathrm{C}\right)$ for nonf ailed fuel rods

b) exposed fue 1 surface temperatures of $\leq 670 \mathrm{~K}\left(400^{\circ} \mathrm{C}\right)$ for failed fuel rods.

For dry storage of spent fuel rods with unbreached Zircaloy cladding, the highest permissible cladding temperature from this study is proposed to be $650 \mathrm{~K}\left(380^{\circ} \mathrm{C}\right)$ in helium or air. The cladding temperature limit for spent fue 1 rods with unbreached Zircaloy cladding in dry storage could be increased to perhaps $770 \mathrm{~K}\left(500^{\circ} \mathrm{C}\right)$ if the fuel rods were vented and subsequently resealed prior to storage in helium. Lower temperatures and an inert gas cover would be required for dry storage of spent fue 1 rods with breached cladding. The proposed temperature limit of $470 \mathrm{~K}\left(200^{\circ} \mathrm{C}\right)$ associated with $\mathrm{UO}_{2}$ oxidation in breached fuel rods in air is the lowest and limiting value. 


\subsection{POTENTIAL AREAS FOR FUTURE WORK}

Areas where supplemental data would be useful, some experiments of possible interest, and some recommended areas for studies on crud are discussed below.

\subsection{AREAS WHERE SUPPLEMENTAL DATA WOULD BE USEFUL}

Supplemental data in these five areas would be useful: definitions, detection of incipiently failed fuel rods, punctured fuel rods that resealed, changes in fuel design and duty, and test prototypicality.

\subsubsection{Definitions}

A recent study $(3,4)$ by PNL for the NRC pointed out that the definition of failed fuel is linked to functional, legal, and detect ion requirements on domestic LWR fuel. Hence, what is considered to be failed fuel can vary from one reactor outage to another and from one fuel reload to another for each utility as requirements change. It is also noted that the threshold for what constitutes abnormal degradation is not uniform and continues to be a matter of opinion. Thus, the degree of degradation reported is not uniform. As a result, there is a need to develop a glossary of spent LWR fuel terminology for use in all reporting.

\subsubsection{Detection of Incipiently Failed Fuel Rods}

The detection of failed LWR fuel rods (i.e., other than visually identified failed rods) is currently a reasonably established procedure, using either or both eddy-current and ultrasonic testing; but the detection of incipiently failed fuel rods is not. $(3,5)$ As Roberts $(5)$ points out, there is a need for improvement in fuel rod defect detection. This is a particularly important area because the greatest potential for radionuclide release in handling/ transporting operations is associated with fuel rods that have sustained some damage short of cladding failure during prior duty (i.e., the fuel rods have incipient defects; see Section 4.2.1). 


\subsubsection{Punctured Fuel Rods That Resealed}

There is a trend toward more pools ide and fewer hot cell examinations of LWR fuel. (5) Fission gas release measurements were previously made in the hot cell, but two domestic fuel vendors have recently developed poolside fission gas release measuring equipment that has the capability for obtaining gas release data on many fuel rods. Such fuel rods are resealed after puncturing but would have to be considered as failed ${ }^{(5)}$ from the viewpoint of subsequent handling/transporting operations. It would be desirable to collect data on the effectiveness of the resealing techniques during subsequent interim storage of and handling/transporting operations with such rods.

\subsubsection{Changes in Fuel Design and Duty}

Prepressurized spent fuel is of concern in storage because of the stored energy of the gas pressure; the probability of cladding failure increases with increased internal fuel rod prepressurization. The fuel rod internal pressure also depends upon irradiation history, especially if a substantial amount of fission gas is released from the fuel into the rod void volume. Relatively few spent LWR fuel bundles with prepressurized rods are currently in interim pool storage although there are a large number that are rapidly nearing the end of their normal duty cycles.

A number of fuel design changes are currently being tested in reactors in an effort to find a remedy for the PCI problem with Zircaloy-clad fuels. Such changes include the use of annular fuel pellets, cladding coated on the inner surface with graphite or siloxane, or cladding with a liner or barrier.

Extended-burnup or high-burnup fuels constitute another area in which fuel handling, shipping, and storage data are lacking. One fuel vendor has an a11-Zircaloy assembly with an intended $10 \%$ increase in burnup (i.e., to $36.0 \mathrm{MWd} / \mathrm{kgU}$ ) that could be on the fuels market in about 1985 . However, fuel designed for burnups to $45.0 \mathrm{MWd} / \mathrm{kgU}$ is not expected to be in general use until about 1990. Data on high-burnup fuels that are obtained by extending the burnup of current fuel designs may be misleading because the fuel rods would operate at a lower linear heat generation rate (LHGR) than rods specifically designed for high burnup. The resulting interior and exterior corrosive attack 
on the cladding and fuel-cladding mechanical interaction would be representative of the lower LHGR and may not represent high-burnup fuel performance at a11. Information is needed on the storage, handling, and transport of fuel that was specifically designed for extended burnup and operated accordingly to achieve that goal. Data are starting to become available on the irradiation performance of a limited number of fuel bundles and fuel rods associated with extended-burnup demonstration programs.

\subsubsection{Test Prototypical ity}

The ever-present question of prototypicality is especially evident in the case of testing extended-burnup fuels as well as in several other areas of testing. How may typical fuel behavior be characterized when there are no typical reactor cycles? One suggestion is to bracket the desired condition rather than trying to match it. A well-designed test of the limiting conditions can often yield a great deal of useful information without having to be prototypic.

\subsection{EXPERIMENTS OF POSS IBLE INTEREST}

The postulated behavior for al ready-damaged fuel rods (see Section 4.3) has not yet been confirmed by experiments.

There have been no systematic experiments on either irradiated or unirradiated fuel rod cladding to identify and quantify the effects of the interstitial-dislocation interaction on fracture toughness, crack growth rates, fatigue endurance limits, and either time-dependent or -independent SEAF material indices. It does not now appear feasible to set any practical limit for transport and subsequent handling without further experimentation and/or analyses. For fue 1 transport in dry and/or noncooled shipping casks, limit considerations (i.e., to avoid the activation of fuel degradation/failure mechanisms) must include time, temperature, vibration, and shock as a minimum.

Several other areas were identified where additional studies appear to be needed. Those areas are indicated below: 
- stress rupture testing of spent fuel rod cladding (see Section 4.3.2)

- experiments to determine the threshold stress intensity, KI scc' for SCC of Zircaloy cladding on spent fuel rods (see Section 4.3.2)

- development of a sorting technique to identify fuel rods with degraded cladding (see Section 4.1), with particular emphasis on developing inspection techniques for detecting spent fuel rods with incipient cladding defects

- experiments to establish the allowable acceleration that can be tolerated by fuel bundles, fuel rods, and containers of fuel rods during handling, transporting, and packaging without causing excessive damage (see Section 4.3.4 and 4.3.6).

Experimental data are needed on impact loads during transport of fuel bundles with sound fuel rods and bundles with fuel rods that were already damaged in prior duty. Such data are also needed for similar fuel rods (from disassembled fuel bundles) that are in close-packed arrays in containers that are being transported. For sound fuel, an analysis of the potential effects of vibration during transport is the minimun requirement.

There are currently three basic shipping cask designs (General Electric, Nuclear Assurance Corporation, TransNuc lear) for two kinds of fuel (PWR and BWR) that will carry the majority of commercial spent fuel bundles or containers with close-packed arrays of fuel rods. Different baskets are used for PWR and BWR fuel. If not already included in other projects, experiments should be conducted to evaluate the vibration/shock spectrum or power spectral density (PSD) expected during normal shipping and during accidents. In addition, experiments should be performed to study the behavior of fuel bundles or containers of close-packed arrays of fuel rods that involve rods with brittle cladding, including fuel rods with damaged cladding, in response to shipping forces. Such tests could involve the preparation of test specimens of hydrided Zircaloy cladding to simulate irradiation embrittlement and the acquisition of actual irradiated cladding. 


\subsection{RECOMMENDED AREAS FOR STUDIES ON CRUD}

Four areas are recommended for future study: coolant chemistry, crud characterization, crud behavior, and projections of the amounts of crud of fuel in future shipments.

\subsubsection{Coolant Chemistry}

Control of coolant chemistry is one of the major methods used to minimize plant radioactivity buildup and thereby reduce the costs associated with maintenance and repair in a radiation field (which can exceed $\$ 2$ million per year per plant). Cohen ${ }^{(69)}$ reviewed the state of the art of coolant technology up to 1968; more recently, Solomon ${ }^{(70)}$ presented an overview of water chemistry for PWRs. Attempts have also been made to construct crud transport models and to explain the crud transport phenomenon. (71-76) These models differ mainly in the use of mass transfer coefficients (phenomenological or empirical).

Recent concerns in coolant chemistry technology include the projected shortage of highly enriched $99.99 \%{ }^{7} \mathrm{Li}$ for the control of reactor coolant $\mathrm{pH}$, the availability of anion resins for minimizing chloride elution problems, and the additional in-service inspection requirements for the integrity of steam generator tubes (which subject plant personnel to radiation exposure). (77) Because coolant chemistry is currently the primary control employed to minimize crud production, more studies are needed to define the correlation between coolant chemistry and crud buildup and to understand the crud transport mechanism. Changes in system design, material selection, and operating conditions may be needed to obtain better control of the chemical properties and radioactivity level in the coolant as well as in the crud.

\subsubsection{Crud Characterization}

Transport and deposition of corrosion products are the cause of a variety of problems in the operation of both nuclear and conventional steam-producing plants. In nuclear power plants, however, the corrosion products (crud) become radioactive under neutron irradiation. As the crud moves through or deposits in the reactor core, it produces radiation fields in the primary circuit, which results in personnel exposure during maintenance and system operation. 
Because it is important to estimate the level of personnel exposure, efforts have been made to measure the crud thickness, determine the crud release rate, and estimate the radioactivity inventory in the primary circuit. (78-80) For example, Roesmer and Rootham ${ }^{(78)}$ measured the crud weight and the equivalent metal release rates in 11 Westinghouse PWR cores (see Table 17).

Roesmer's study has provided the incentive for further investigations to verify mathematical and empirical estimates. Because the success of such efforts is closely tied to the depth of our understanding of crud properties, emphasis should be placed in the following areas:

- development of crud measurement techniques

- study of crud distributions in- and out-of-core

- analysis of crud composition

- development of a better understanding of crud deposition chemistry and patterns

- prediction of crud activity during reactor operation and shutdowns.

TABLE 17. Weight of Metal Released to the Primary System of a 1000-MWe PWR (a)

\begin{tabular}{|c|c|c|c|c|}
\hline $\begin{array}{l}\text { Corrosion } \\
\text { roduct Source }\end{array}$ & $\begin{array}{l}\text { Area in } \\
\text { Primary } \\
\text { System, } \\
\text { dm }\end{array}$ & $\begin{array}{l}\text { Weight of } \\
\text { After } \\
\text { Two Months }\end{array}$ & $\begin{array}{c}\text { Meta } 1 \text { (Crud) } \\
\text { After } \\
\text { One Year }\end{array}$ & $\begin{array}{r}\text { Released, } \mathrm{kg} \\
\text { Each Year } \\
\text { After First }\end{array}$ \\
\hline $\begin{array}{l}\text { Stainless steel } \\
\text { (Type } 304 \text { ) }\end{array}$ & $2.16 \times 10^{5}$ & $0.4(0.6)$ & $1.5(2.1)$ & $1.3(1.9)$ \\
\hline-600 & $.84 \times 10^{6}$ & $22.0(31.4)$ & $49.5(70.7)$ & $33.0(47.1)$ \\
\hline
\end{tabular}

(a) This table was extracted from Table 2 of Reference 78.

\subsubsection{Crud Behavior}

One of the major concerns with crud buildup on fuel rods is the resulting effect on cladding temperature. ${ }^{(81-83)}$ Thick crud deposits $(-0.1 \mathrm{~mm})$ on highly rated regions of fuel rods can sometimes lead to defects during reactor operation because of localized overheating. Pickman ${ }^{(84)}$ explained the possible cause of the temperature increase and suggested several remedies. 
The success of these remedies has yet to be proven. Further research is needed to understand crud behavior in various reactor environments and on different fuel and structural materials.

\subsubsection{Crud on Shipped Fuel}

It is difficult to predict the changes in crud characteristics that might occur during shipping. Crud particles deposited on fuel bundle and fuel rod surfaces can loosen during shipping and scatter in the shipping cask, causing possible additional exposure to personnel subsequently engaged in removing the fuel from the cask. In a recent report on spent fuel handling activities associated with spent LWR fuel shipments received at General Electric CompanyMorris Operation, Eger and Zima ${ }^{(15)}$ described several methods for minimizing the release of radioactive materials. These methods included protecting the cladding integrity, containing the spent fuel storage basin water, removing radionuclides and other contaminants from the water, and filtering followed by dispersing of the basin air. These methods have been proven successful. Possible effects of crud layers on spent fuel rods and other fuel bundle components are also discussed in References 22 and 44 . In another report (14) it was recommended that all receiving facilities, especially dry ones, be designed to adequately deal with external contamination or crud (loose and fixed) on spent LWR fuel. 


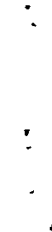




\subsection{REFERENCES}

1. U.S. Nuc lear Regulatory Commission. 1982. Licensed Operating Reactors, Status Summary Report, Data as of 12-31-81. NUREG-0020, 6(1):3-2 and 3-3, Washington, D.C.

2. Bosi, D. M. 1981. An Assessment of Spent Fuel Structural Integrity Under Disposal Cycle Conditions. HEDL-TME 80-84, Hanford Engineering Development Laboratory, Richland, Washington.

3. Bailey, W. J., et a1. 1980. Assessment of Current Onsite Inspection Techniques for Light-Water Reactor Fuel Systems: Executive Summary. NUREG/CR-1380, PNL-3325, Vo1. 1, Pacific Northwest Laboratory, Richland, Washington.

4. Bailey, W. J., et a1. 1980. Assessment of Current Onsite Inspection Techniques for Light-Water Reactor Fuel Systems: Discussion of Inspection Techniques. NUREG/CR-1380, PNL-3325, Vol. 2, Pacific Northwest Laboratory, Rich land, Washington.

5. Roberts, J.T.A. 1980. "Nuclear Fuel NDE." Third International Conference on Nondestructure Evaluation in the Nuclear Industry, February 11-13, 1980, Salt Lake City, Utah.

6. Davidson, R., and D. Deacon. 1980. "Spent-Fuel Storage." In Proceedings of International Conference on World Nuc lear Energy Accomplishments and Perspectives, 37:136-147. Conference cosponsored by Am. Nuc T. Soc. and European NucT. Soc., Washington, D.C.

7. U.S. Department of Energy. 1982. Spent Fuel Storage Requirements (An Update of DOE/SR-007). DOE/RL-82-1.

8. Johnson, A. B., Jr., et al. May 1980. Annual Report-FY1979, Spent Fuel and Fuel Pool Component Integrity. PNL-3171, Pacific Northwest Laboratory, Richland, Washington.

X 9. Johnson, A. B., Jr., and W. J. Bailey. 1980. Scientific Basis for Confidence that Spent Fuel $C$ an Be Stored Until Geologic Disposal Facilities Are Available. PNL-SA-8197, contribution to Section IV, "Extended Storage Assessment," of the DOE Draft for NRC Confidence Rule Making, DOE/NE-007, April 15, 1980, Pacific Northwest Laboratory, Richland, Washington.

10. Johnson, A. B., Jr. 1977. Behavior of Spent Nuclear Fuel in Water Pool Storage. BNWL-2256, Pacif ic Northwest Laboratory, Richland, Washington.

11. Johnson, A. B., Jr. 1979. "Spent Fuel Storage Experience." Nucl. Tech. 43:163-172. 
12. Johnson, A. B., Jr., et a1. October 1980. "Significance of Shippingport and Connecticut Yankee Fuel Examinations to Extended Water Storage of LWR Fuel." PNL-SA-8833, presented at the IAEA Advisory Group/Specialists" Meeting on Spent Fuel Storage Alternatives, Las Vegas, Nevada, November 17-21, 1980 .

13. Bailey, W. J., et al. 1980. "Spent Fuel Behavior in Water Pools." PNL-SA-9055, in Proceedings of CORROSION/81, the International Corrosion Forum sponsored by the National Association of Corrosion Engineers (NACE), Toronto, Ontario, Canada.

14. Funk, C. W., and L. D. Jacobson. 1979. Inventory and Characterization of Spent LWR Fuel. HEDL-TME 77-82, Hanford Engineering Development Laboratory, Richland, Washington.

15. Eger, K. J., and G. E. Zima. 1979. Commentary on Spent Fuel Storage at Morr is Operations. NUREG/CR-0956, PNL-3065, Pacific Northwest Laboratory, Richtand, Washington.

16. Astrom, K. A., and K. J. Eger. 1978. Spent Fuel Receipt and Storage at the Morris Operation. NEDG-21889, General Electric Company, San Jose, California.

17. Funk, C. W., and L. D. Jacobson. 1980. Spent Fuel Integrity During Transportation. HEDL-TME 78-58, Hanford Engineering Development Laboratory, Richl and, Washington.

18. Bailey, W. J. 1974. Fuel Failures in Commercial Nuclear Power Reactors. Prepared by Pacific Northwest Laboratory for the Quality Assurance Branch, Directorate of Licensing, U.S. AEC, under contract AT(45-1)-1830.

19. Bobe, P. E. January 1976. Fuel Performance of Licensed Nuclear Power Plants Through 1974. NUREG-0032, U.S. Nuclear Regulatory Commission, Washington D.C.

20. Bailey, W. J., and D. C. Langstaff. 1980. "Experience with Fuel Damage from Abnormal Conditions in Handling and Transport." Sixth International Symposium on Packaging and Transportation of Radioactive Materials (PATRAM '80), 2:1113-1120, November 10-14, 1980, West Berlin, Feder al Republic of Germany. Published by K. 0. Storck and Co., Verlag und Druckerei GmbH, Hamburg.

21. Urbanic, V. F., R. Gray, and D. H. Lister. 1979. Review of In-Reactor Zircaloy Corrosion and Crud Deposition Experience at AECL. EPRI NP-1254, prepared for the Electric Power Research Institute by the Atomic Energy of Canada Research Company, Chalk River, Ontario, Canada.

22. Zima, G. E. 1978. Comments on Fuel Crud as a Safety and Operational Factor of Independent Spent Fuel Storage Installations. PNL-2657, Pacific Northwest Laboratory, Richland, Washington. 
23. Tokar, M., W. J. Bailey, and M. E. Cunningham. 1980. Fuel Performance Annual Report for 1979. NUREG/CR-1818, PNL-3583, U.S. Nuc Tear ReguTatory Commission, Washington, D.C.

24. Boyle, E. L. May 1980. LER Monthly Report (April 1980). U.S. Nuclear Regul atory Commission, Washington, D.C., p. 40, LER No. 80-004/0 IT-1, Docket 50309, Maine Yankee.

25. Sofer, G. A., and K. N. Woods. 1979. "Non-Destructive Examination of Exxon Nuc lear Fuel in LWR Reactors." In Proceedings of Am. Nuc l. Soc. Topical Meeting on Light Water Reactor Fuel Performance, Apri1-May 1979, Portland, Oregon, pp. 39-48.

26. Solomon, Y., and J. Roesmer. 1976. "Measurement of Fuel Element and Deposits in Pressurized Water Reactors." J. Nucl. Tech. 29:166-173.

27. Melehan, J. B., et al. 1979. "Evaluation and Performance of Westinghouse $17 \times 17$ Fuel." In Proceedings of Am. Nuc 1. Soc. Top ical Meeting on Light Water Reactor Fuel Performance, April-May 1979, Portland, Oregon, pp. 29-38.

28. Leech, W. J., et al. 1979. "High Burnup Experience in PWRs." In Proceedings of Am. Nucl. Soc. Topical Meeting on Light Water Reactor Fuel Performance, April-May 1979, Portland, Oregon, pp. 104-112.

29. Berry, W. E., and R. B. Diegle. 1979. Survey of Corrosion Product Generation, Transport, and Deposition in Light Water Nuclear Reactors. EPRI NP-522, Electric Power Research Institute, Palo ATto, California.

30. Franklin, D., H. Ocken, and T. Olberg. 1981. LWR Core Materials Performance Program: Progress in 1979-1980. EPRI NP-1770-SR, Electric Power Research Institute, Palo Alto, California.

31. Enge1, R. E. (General Electric Company). 1980. Letter to M. Tokar (U.S. Nuclear Regulatory Commission), "Corrosion Product Control." October 3, 1980. (Available at the Nuclear Regulatory Commission's Public Document Room in Washington, D.C.)

32. Morikawa, Y., Y. Meguro, and T. Kamata. 1981. "Analysis on the Primary System Radiation Control at Tsuruga Boiling Water Reactor Plant." Nucl. Tech. 52(1):7-21.

V 33. Melehan, J. B. 1971. Yankee Core Evaluation Program, Final Report. WCAP-3017-6094, Westinghouse Electric Corporation, Pittsburgh, Pennsylvania.

34. Letter, R. H. Peterson, Pacific Gas and Electric Company, to U.S. AEC. "Report on Fuel Assembly Cladding Defect Determinations Using the 'Dry Sipping' Technique and Report on Increased Core Flow Resistance Due to Corrosion Product Scaling of Fuel." Docket 50133-4, February 24, 1966. 
35. Benjamin, A. S., et al 1979. Spent Fuel Heatup Following Loss of Water During Storage. NUREG/CR-0649, SAND 77-1371, Sandia Nat ional

Laboratories, Albuquerque, New Mex ic 0.

36. Boase, D. G., and T. T. Vandergroff. 1977. "The Canadian Spent Fuel Storage Canister: Some Material Aspects." Nuclear Tech. 32:60-71.

37. Eister, W. K. 1977. "Materials Cons iderations in Radioact ive Waste Storage." Nuclear Tech. 32:6-9

38. Off ice of Nuclear Materials Safety and Safeguards. March 1978. Handling and Storage of Spent Fuel. NUREG-0404, Vol. 2, Appendix B, U.S. Nuclear Regulatory Comm ission, Wash ington, D.C.

39. Moore, E. L., and D.B. Coleman. 1978. Radioact ive Waste Package Accept ance Criteria. RHO-CD-568, Rock velT Hanford Operat ions, Richland, Washintgon.

40. Turner, S. E., W. J. Elgin, and R. P. Hancock. 1979. Historical Survey of Nuclear Fuel Utilization in U.S. LWR Pover Plants. SSA-122, Southern Science Applic at ions, Inc., Dunedin, Flor ida.

41. Pitek, M. T. 1976. "Util ity Experience in LWR Fuel Performance." NUSCO-115, presented at the Joint ANS/CNA Meeting, Toronto, Ontario, Canada, June 13-18, 1976.

42. Elk ins, R. B. 1977. Experience with BWR Fuel Through December 1976. NED0-21660, General Electric Company, San Jose, Cal ifornia.

43. Blackburn, L. D., et al. May 1978. Maximum Allo wable Temperature for Storage of Spent Nuclear Reactor Fuel. HEDL-TME-78-37, Hanford Eng ineer ing Development Laboratory, $R$ ichland, Wash ington.

44. Zima, G. E. May 1979. An Evaluation of Potential Chemical/Mechanical Degradation Processes Affecting Fuel and Structural Materials Under Long-Term Water Storage. NUREG/CR-0668, PNL-2379, Pac if ic North west Laboratory, Richland, Wash ington.

45. Off ice of Nuclear Reactor Regulation. Standard Rev ie w Plan, NUREG-75/087, U.S. Nuclear Regulatory Commission, Washington, D.C.

46. Courtright, E.L., and R. 0. Meyer. July 1979. A Survey of Potential Light Water Reactor Fuel Rod Failure Mechanisms and Damage Limits. PNL-2787, Pac if ic North vest Laboratory, Richland, Wash ington.

47. Pankask ie, P. J. 1980. Mechan ist ic Cons iderations Used in the Development of the PROFIT PCI Failure Model. NUREG/CR-1462, PNL-3386, Pac if ic North vest Laboratory, Richland, wash ington. 
48. Fuhrman, N., et al. 1976. Evaluation of Fuel Performance in Maine Yankee Core I. EPRI NP-218, prepared by Combustion Engineering Co., for the Electric Pover Research Institute, Palo Alto, California, EPRI Contract RP 586-1.

49. Pasupathi, V., et al. July 1978. Determination and Microscop ic Study of Inc ip ient Defects in Irradiated Pover Reactor Fuel. EPRI NP-812, E lectric Pover Research Institute, EPRI Contract RP 829.

50. Roberts, B. W., F. V. E11 is, and J. E. Bynum. October 1979. "Remaining Creep or Stress-Rupture Life Under Nonsteady Temperature and Stress." J. Eng ineering Materials and Tech. 101:331:336.

51. Woodf ord, D. A. October 1979. "Creep Damage and the Remaining L ife Concept." J. Engineering Materials and Tech. 101:311-316.

52. Chambers, W. L., W. J. Ostergren, and J.H. Wood. 1979. "Creep Failure Criteria for High Temperature Alloys." $J$. of Engineering Materials and Tech. 101:374-379.

53. Pankaskie, P. J. 1980. "Strain Energy Absorption as a Failure Index for Materials Sens it ive to Interstitial-Dislocation-Interaction."

PNL-SA-8597, presented at the International Symposium on Stra in Energy Dens ity and/or Absorbed Spec if ic Energy for Fracture, Budapest, Hungary, September 16-19, 1980.

54. Ostergren, W. September 1976. "A Damage Function and Associated Failure Equations for Predicting Hold Time and Frequency Effects in Elevated Temperature, Low Cycle Fat igue." J. Testing and Evaluation 4(5):327-339.

55. Boresi, A. P., et al. 1978. Advanced Mechanics of Materials. 3rd ed. John Wiley and Sons, New York.

56. Coff in, L.F., et al. January 1977. Time-Dependent Fatigue of Structural Alloys. ORNL-5073, Oak Ridge National Laboratory, Oak Ridge, Tennessee.

57. Monkman, F.D., and N. J. Grant. "An Emp ir ic al Relationsh ip Bet veen Rupture Life and Min imum Creep Rate in Creep-Rupture Tests." ASTM, Vol. 56 .

58. Irwin, G.R. 1960. "Fracture Mechanics." In Structural Mechanics. Pergamon Press, New York.

59. Sih, G. C., and B. Macdonald. 1974. "Fracture Mechan ics Applied to Engineering Problems--Strain Energy Density Fracture Criterion." In Engineering Fracture Mechan ics. Vol. 6. Pergamon Press, New York.

60. Magnuson, C.F., and L. T. Wilson. 1977. Shock and Vibration Environments for Large Shipp ing Containers on Rail Cars and Trucks. SAND 76-0427, Sandia Laboratories, ATbuquerque, Ne w Mexico. 
61. Peehs, M., and G. Kaspar. 1980. "Short Comments on the Status of R\&D Work on the Long-Term Behavior of Spent LWR Fuel." Presented at the BEFAST Meeting, July 23, 1980, Paris, France. The distribution of this document is limited to BEFAST participants.

62. Roberts, J.T.A., et al. 1979. LWR Fuel Performance Program: Progress in 1978. EPRI NP-1024 SR, Electric Power Research Institute, Palo ATto, California.

63. Cubicciotti, D., and R. L. Jones. 1978. EPRI-NASA Cooperative Project on Stress Corrosion Cracking of Zircaloys. EPRI NP-717, ETectric Power Research Institute, Palo Alto, California, p. 6-13.

64. Magnuson, C.F. 1977. Shock and Vibration Environment for Large Shipping Containers During Truck Transport (Part I). SAND 77-1110, Sandia Nat ional Laboratories, A lbuquerque, New Mexico.

65. Edgerton, J. H. 1974. "Military Experience with Packaging and Transportation of Radioactive Materials." In Fourth Proceedings of the International Symposium on Packaging and Transportation of Radioactive Materials, Miami Beach, Florida, CoNf-740901-P2.

66. U.S. Nuclear Regulatory Commission. 1977. Load Combinations for the Structural Analysis of Shipping Casks. NRC Regulatory Guide 7.8, Washington, D.C.

67. Clarke, R.K., and J.J. Foley. 1974. Severities of Transportation Accidents, Vol. II, Motor Carriers. SLA-74-0001, Sandia National Laboratories, Albuquerque, New Mexico.

68. Funk, C. W., L. D. Jacobson, and M. N. Menon. 1979. Effects of Environments on Spent Fuel. HEDL-TME-77-22, Hanford Engineering Development Laboratory, Richland, Washington.

69. Cohen, P. 1969. Water Coolant Technology of Power Reactors. Gordon and Breach, New York.

70. Solomon, Y. 1978. "An Overview of Water Chemistry for Pressurized Water Nuc lear Reactors." In Proceedings of Water Chemistry of Nuc lear Reactor Systems, pp. 101-112, British Nuclear Energy Society, Bournemouth, U.K.

71. Grant, P. J., et a1. 1975. Oconee Radiochemistry Survey Program. RDTPL-75-4, summary of four presentations at Am. Nuc1. Soc. Annual Meeting in New Orleans, Louisiana, June 8-13, 1975, Babcock \& Wilcox Company, Lynchburg, Virginia.

72. Yerazunis, S., et al. 1959. Mechanisms of Reactor System Activation. KAPL-M-SMS-98, Knolls Atomic Power Laboratory, Schenectady, New York.

73. Bartlett, J. W. 1968. Theory of Corrosion Product Generation, Dispersion, and Activation Process. PNL-676, Pacific Northwest Laboratory, Richland, Washington. 
74. Beal, S. K. 1973. "A Model of Crud and Radiation-Level Buildup in Reactor Plants." Trans. Am. Nucl. Soc. 17:163.

75. Lister, D. H. 1976. Predicting Radiation Fields Around Reactor Components. AECL-5522, A tomic Energy of Canada Limited, Chalk River, Ontario, Canada.

76. Burri11, K. A. 1977. "Corrosion Products Transport in Water-Cooled Nuclear Reactors, Part I: Pressurized Water Operation." Can. J. Chem. Eng. 55:54-61.

77. Hicks, J. H. 1976. "Recent Concerns with Reactor Coolant Chemistry Technology in Pressurized Water Reactors." Nucl. Tech. 29:146-150.

78. Roesmer, J., and M. W. Rootham. 1978. "Estimation of Activity Inventories in Primary Circuits of Pressurized Water Reactors." In Proceedings of Water Chemistry of Nuclear Reactor Systems, pp. 187-193, British NucTear Energy Society, Bournemouth, U.K.

79. Solomon, Y., and J. Roesmer. 1976. "Measurement of Fuel Element Crud Deposits in Pressurized Water Reactors." Nuc 1. Tech. 29:166-173.

80. Fletcher, W. D. 1970. "Primary Coolant Chemistry of PWR's." In Proceedings of 31 st International Water Conference, pp. 57-66, Engineers' Society of Western Pennsylvania, Pittsburgh, Pennsylvania.

81. Garlick, A., R. Sumerling, and G. L. Shires. 1977. "Crud-Induced Overheating Defects in Water Reactor Fuel Pins." J. Brit. Nucl. Energy Soc. 16(1):77-80.

82. Macbeth, R. V., et al. 1971. An Investigation Into the Effect of Crud Deposits on Surface Temperature, Dryout and Pressure Drop with Forced Convection Boiling of Water at 69 Bars in an Annular Test Section. AEEW R707, United Kingdom Atomic Energy Establishment, Winfrith, U.K.

83. Videm, K. 1972. "Properties of Zirconium Base Cladding Materials Corrosion and Hydrogen Pickup." Nucl. Eng. and Des. 21(2):200-211.

84. Pickman, D. 0. 1969. Fuel Performance in the Prototype SGHWR Power Station. TRG Report $19 \overline{43}(\mathrm{~S})$, United Kingdom Atomic Energy Authority, Springfields, U.K. 


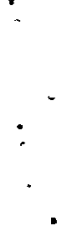




\section{APPENDIX}

SUMMARY OF EXPERIENCE WITH FUEL DAMAGE CAUSED BY ABNORMAL

CONDITIONS DURING HANDLING AND TRANSPORT ${ }^{(\mathrm{a})}$

(a) An earlier and more condensed version of this material was published in: Bailey, W. J., and D. C. Langstaff. 1980. "Experience with Fuel Damage from Abnormal Conditions in Handling and Transport." Sixth International Symposium on Packaging and Transportation of Radioactive Materials (PATRAM '80), 2:1113-1120, November 10-14, 1980, West Berlin, Feder al Republic of Germany. Published by K. O. Storck and Co., Verlag und Druckerei $\mathrm{GmbH}$, Hamburg. 
APPENDIX

SUMMARY OF EXPERIENCE WITH FUEL DAMAGE CAUSED BY ABNORMAL

CONDITIONS DURING HANDLING AND TRANSPORT ${ }^{(a)}$

OPERATION

Receiving New Fuel

- During transfer of a fresh PWR fuel bundle from shipping container to inspection location, the fuel bundle was dropped $1.5 \mathrm{~m}(5 \mathrm{ft})$ to the floor when the fuel-handling tool cable pulled free from its swaged fitting. No fuel rods ruptured, and no radioactive material was released; but some fuel rods were bowed, there were broken spacer grids, and the fitting at the lower end was bent. (1)

- During receiving inspection of fresh PWR fuel, a condition of noncontact between some Zircaloy grid spring fingers and fuel rods was noted, which was believed to be caused by excessive lateral loads applied to fuel rods during handling or shipping. (2)

Refueling Reactor Core

Fresh Fuel Bundles

- Cable clamps did not grip the cable while a fresh PWR fuel bundle was being raised to the vertical position during initial core loading. The bundle was dropped to 0.10 or $0.13 \mathrm{~m}$ ( 4 or $5 \mathrm{in.}$ ). The bundle skeleton was replaced before the bundle was loaded into the core. (3)

- Two fuel rods in a fresh PWR fuel bundle were damaged when it was being loaded into the core between two slightly distorted fuel bundles. One rod came out of the upper end fitting and one rod was bent; but no cladding failure was observed. (4)

- Minor spacer grid damage to one fuel bundle was observed at one BWR: bottom strap on spacer grjd nearest bottom of fuel bundle was displaced upward $\sim 3 \mathrm{~mm}(\sim 0.12 \mathrm{in.}) .(5)$ Damage believed to have occurred as the new bund le was inserted into a sipper-stripper (round pipe) with edges that were not properly designed for receiving a stripped (shroudless or dechanneled) fuel bundle. The damage did not preclude proper installation of the channel on the bundle.

(a) Entries involve irradiated fuel in almost all cases. A few pertinent entries involving fresh (unirradiated) fuel have also been included. $\mathrm{PWR}=$ pressurized water reactor; $\mathrm{BWR}=$ boiling water reactor; $\mathrm{PHWR}=$ pressurized heavy-water-moderated reactor. 
Irradiated BWR Fuel Bundles

- During transfer of BWR fuel from the core to a fuel storage pool, one fuel bundle (A) that had a burnup of $291 \mathrm{GJ} / \mathrm{kgU}(3.365 \mathrm{MNd} / \mathrm{kgU})$ was inadvertently dropped $9.1 \mathrm{~m}(30 \mathrm{ft})$ onto another fuel bundle $(B)$ in the core. The lower tie plate cage on $A$ was deformed upwards toward the tie plate. The bail handle on B was deformed almost horizontally; the channel was driven downward so that its lower edge flared over the lower tie plate shoulder. Movement of $B$ placed a tensile force on the fuel rods; and during this movement, there was a temporary increase in airborne radioactivity, which apparently indicated that the fuel rods had been damaged to some extent. Channels on two fuel bundles that were adjacent to $B$ were dented on the top edge. (6)

- During unloading of the core, a channeled BWR fuel bundle came loose from the grapple and dropped about $3.7 \mathrm{~m}(12 \mathrm{ft})$ to the transfer pool floor. No gaseous release was noted, and there was no apparent damage to the fuel bundle. $(7)$

- A BWR fuel bundle was dropped during core loading. (8)

- Irradiated fuel bundles discharged at a BWR included one bundle that experienced a grappling problem and one dropped bundle. (9-11)

- Refueling grapple unexpectedly lowered (due to broken switch) and a BWR fuel bundle bumped against the reactor vessel. (12)

- One BWR fuel bundle was damaged during a refueling outage.(13)

- Improper use of hoist cable tensiometer instrument during shuffling of BWR fuel caused a handling problem. Spacer grid damage to one fuel bundle was extensive and beyond repair. No evidence of damage to the fuel rods could be detected. $(14-17)$

- Three BWR fuel bundles were not fully seated in core because the spring clips were hung up on the core upper grid. The small difference in relative bundle height was not recognized in the core verification. $(18,19)$

- Bowing of fuel rods was observed. Shroud locking rings had been unlocked during previous operations, which caused the BWR fuel bund les to be improperly seated and produced twisting and stressing of the fuel bundles.(20)

- When changing orientation of BWR fuel bundles at a foreign BWR, the general-purpose grapple sometimes became entangled with the fuel bund le bail and was difficult to release. The problem was reduced substantially by using a special orientation rig. (21)

- Grapple caught bail of dummy fuel at a foreign BWR twice; each time dummy fuel slipped off while being lifted.(21) 
- Many freely supported spacers on top grid of core were found to bend or gall on fuel bundles at a foreign BWR. (21)

- Mechanical interference between fuel bundle channels and control blades was noted at a foreign BWR. (22)

- Fuel bundles at a foreign BWR (pressure tube type) became detached from the hanger bars and lodged at bottom of pressure tubes. Damage to bundles was slight. (23)

\section{Irradiated PWR Fuel Bundles}

- When the upper core barrel was lifted, a PWR fuel bundle stuck to it. (Hang-up was caused by a small foreign object that locked the bundle in place. Marks were found on the upper core support plate.) The bundle was lifted $2.4 \mathrm{~m}(8 \mathrm{ft})$ above the core. While trying to reinsert the bundle, it was dislodged and fell several centimeters to the top of core adjacent to its original position. Upper nozzle and upper fuel bundle wrapper sheet were damaged. $(24-26)$

- After a PWR fuel bundle was lowered into the core and released, it tipped about 0.6 to $0.8 \mathrm{~m}$ ( 24 to $30 \mathrm{in.)}$ onto the core baffle. No visible damage to the fuel bundle was noted. Apparently, the bottom nozzle of bundle was not properly lowered onto its locator pins. (27-28)

- One PWR fuel bundle tipped against a corner of the core shroud during fuel loading. Core support plate fuel guide pins were improperly located.(29)

- While withdrawing a PWR fuel bundle from the core, one peripheral fuel rod was bowed outside the envelope of the bundle (as noted with the refueling machine camera). The fuel rod ( $\mathrm{fifth}$ from the right) was bowed outside the bundle envelope between the fourth and fifth grids from the top of the bundle. The rod had apparent cladding failure. No evidence of damage due to the bowed fuel rod was observed in the adjacent fuel bundle. (30)

- Two PWR fuel assemblies were examined thoroughly because of reportedly higher than normal loads during their removal from the core. (31) The examinations revealed no anomalies or atypical appearances.

- Some trouble in refueling was encountered due to the bowed fuel rods in PWR fuel bundles. (32)

- Basket containing in-core loading detector was being removed at a PWR and caught under hold-down plate of an adjacent fuel bundle, lifting it off its four alignment pins and damaging two spacer grids. (33)

- Bowed fuel rods resulted in some fuel loading problems at a PWR Damaged spacer grids were noted on 29 of the PWR fuel bundles. $(32,34-38)$ 
- Two small sections of a spring clip grid spacer on a PWR fuel bundle were found in the steam generator. Six fuel rods were partially unsupported at that grid location. The grid edge probably caught on some portion of an adjacent bundle during refueling operations; however, there was no apparent damage to other bundles. $(39,40)$

- Corner interaction between grid straps on adjacent fuel bundles caused grip strap damage on 31 PWR fuel bundles during fuel handing operations. of the 31 bundles, 15 had small pieces missing, 5 had grid material ripged and laid over, and 11 had larger sections missing (up to about $0.0035 \mathrm{~m}^{2}$ or $5.5 \mathrm{in.}^{2}$ ) and fuel rods exposed (i.e., they were no longer fully restrained in the manner provided for in the design). About 61 pieces (a total area of about $0,016 \mathrm{~m}^{2}$ or $25 \mathrm{in.}^{2}$ ) were missing. No damage to fuel rods was noted. $(41,42)$

- Each of two PWR fuel bundles had a damaged grid. (43) Two other fuel bundles registered high loads when they were removed from the core; inspection of these and adjacent fuel bundles indicated no damage.

- During fuel shuffle operations at a PWR, some fuel assemblies experienced handling difficulties. (44) Grid strap damage in the form of torn or missing corners was observed on 87 fuel assemblies. No damage to the cladding on the fuel rods was identified. The grid strap damage was caused by corner-to-corner interaction between adjacent assemblies during the fuel handling operations.

- During May 1974 to May 1978, one fuel assembly at each of four different PWRs was found to have grid strap damage. (45) The damage occurred while the assemblies were being moved during core refueling operations.

- At three domestic PWRs and one foreign PWR that underwent refueling in 1979, two or three fuel assemblies at each plant sustained grid strap damage. (46) The grid damage was minor on a number of these assemblies.

- A problem in fuel handling was encountered that involved interference of adjacent fuel assembly spacer grids as the fuel assemblies were removed from the PWR core. (47) Thirteen fuel assemblies showed some evidence of possible handling interferences and three had spacer grid damage serious enough that they were examined and repaired.

- Spacer grid damage was observed on five PWR fuel assemblies. The damage to two of the assemblies was extremely minor, but the damage to three was significant. (48) The damage occurred during fuel handling following the first cycle of operation.

- During refueling at a PWR in 1980, two fuel assemblies were found to have damaged grids. $(49)$ The damage occurred during insertion of these assemblies into the core.

- Lower nozzle on one PWR fuel bundle was jarred during core loading. (50) 
- Top nozzles on two PWR fuel bundles separated from the perforated stainless steel can (tack welds joining can to nozzle failed) durjng refueling operation and at cask loading operations at spent fuel pool.(51)

- Mechanical damage caused bent nozzle springs in three PWR fuel bundles. $(40)$

- Two of four hold-down springs on the top nozzle of a PWR fuel bund le were damaged when another fuel bundle was allowed to rest on top of it. $(52,53)$

- Control blade binding was caused by bent guide rod nut capture devices on two adjacent PWR fuel bundles. Twenty bent nut capture devices were found on fuel bund les in that PWR core. The devices bend very easily, and it is difficult to insert a control b]ade by crane without having the blade catch on the fuel bundle edges. 54 )

- One irradiated PWR fuel bundle was slightly damaged when, after lowering the bundle into the core, the refueling machine mast was rotated prior to raising the fuel spreader, which twisted the top of the bundle with respect to the bottom. Inspection of the bundle in the spent fuel pool indicated that the damage was minor. Adjacent bundles were visually examined; no significant indications were noted. (55)

- At one PWR, difficulty was experienced in removing a burnable poison assembly from a fuel assembly. $(56)$

- Two burnable poison rods remained fixed in the fuel assemblies at a foreign PWR for unknown reasons. (57)

- One burnable poison rod (it was broken $0.6 \mathrm{~m}$ from the top) was found jammed in the thimble tube of a PWR fuel assembly. (58)

- At one PWR, a secondary source assembly stuck in a fuel assembly and could not be removed. (59)

- At one PWR, a source assembly could not be removed from each of two fuel assemblies. $(60)$

- A plugging device stuck in one PWR fuel assembly. The assembly was scheduled for discharge and was not reused. (61)

- A crane operator mispositioned a spent PWR fuel bundle and damaged the bundle and the refueling equipment. (62)

- Difficulties were encountered with fuel handling equipment at one PWR.(32)

- A PWR fuel assembly at a foreign reactor was dropped $\sim 0.5 \mathrm{~m}$. (63) The fuel rods were hermetic, but the shroud tube that covers the assembly had some dimensional changes because of deformation. 

- Damage, to foreign PWR fuel bundles was caused by leveling bolts and
shims. $(64)$

- One foreign PHWR fyel bundle failed because of mechanical damage due to a handling incident. (65)

- Five foreign PHWR fuel bundles failed because of maloperation of fuel loading equipment. $(66)$

- One potential failure mechanism for foreign PHWR fuel bundles was mechanical damage during fuel handing. (67)

- Some fuel failures at a foreign PHWR were caused by fueling machines during unusual maneuvers; a few may have been damaged by handling equipment only after discharge. $(68-70)$

Storage and Handling of Fuel at Spent Fuel Pool

Fuel Rods

- Spent tie rod from a BWR fuel bundle was unexpectedly found on spent fuel pool floor; upper shank of this tie rod was broken, but the integrity of the fuel rod was not affected. Rod was apparently misplaced in January 1972. It was to have been in corner rod position in a fuel bundle that was shipped to off site reprocessor in June 1973. $(71,72)$

- Experience with fuel bundle rebuilding at foreign BWRs has been good; 1085 bundles were rebuilt and not a single fuel rod was dropped. (73)

BWR Fuel Bundles

- During transfer, an irradiated BWR fuel bundle became detached from grapple and fell about $6 \mathrm{~m}(20 \mathrm{ft})$ in the spent fuel pool. Grapple hook apparently was not completely latched under handle of the fuel bundle. There was no measurable release of radioactivity. The nose piece and the nose piece end of the fuel channel were crushed; there were no indications of broken fuel rods. (74)

- Because of improper grappling, an irradiated BWR fuel bundle was dropped about $1.8 \mathrm{~m}(6 \mathrm{ft})$ to the spent fuel pool floor and then tipped over into the corner of the pool in the $3-m(10-f t)$ deep spent fuel cask pit. When the fuel bundle was lifted to a vertical position, the channel fell off and fuel rods came out of the bundle. Apparently, the fuel bund le separated because the tie rods and $(g r$ tie rod keepers had been sheared when the bundle hit the pool floor. $(75,76)$

- One BWR fuel bundle fell from the fuel preparation machine from a vertical to a horizontal position. Only three other fuel bundles were struck or could have been struck by the falling bundle. The fuel bundle that fell was not visibly damaged; however, the bail of another fuel bundle was 
bent. Preliminary visual inspection of the two other bundles indicated localized scratches or crud removal on the bails. Inspection of the fuel preparation machine indicated that the upper roller guide had separated from the carriage. $(77)$

- While transferring an unchanneled spent BWR fuel bundle from a fuel preparation machine to a spent fuel rack in the fuel pool, the bundle fell about $1.5 \mathrm{~m}(5 \mathrm{ft})$ from the main grapple to the pool floor because of a grapple design deficiency. No release of radioactivity was measured even though the bundle was damaged (visual inspection of bundle revealed it to be considerably bowed over its whole length). (78)

- A foreign BWR fuel bundle with a burnup of $950 \mathrm{GJ} / \mathrm{kgJ}(11.0 \mathrm{MWd} / \mathrm{kgU}) \mathrm{fell}$ $8 \mathrm{~m}(26 \mathrm{ft})$ to bottom of spent fuel pool. No release of radioactivity was detected.(73)

- A foreign BWR fuel bundle fell several centimeters when the galvanized grapple rope snapped. Bundle came to rest on top of spent fuel storage rack. Spacer grids on bundle were displaced; the cone piece on the bottom tie plate was dented.(21)

PWR Fuel Bundles

- The spent fuel pool side lifting frame struck one PWR fuel bundle when the lifting frame was suspended (lateral movement occurred before crane had lifted fuel bundle to "full up" position). There was no breach of fuel rod cladding. Two fuel rods on the periphery of the bundle were bent. cladding on the two fuel rods was sound, but rod deformation was extensive enough to render them unacceptable for further use. One grid spacer (the first one above the bottom nozzle) on the bundle also sustained damage. (79)

- One PWR fuel bundle slightly bumped the side of the reactor containment vessel during transfer to the spent fuel pit. No damage was noted. (43)

- Plant-fabricated crane hook failed while moving new fuel elevator test weight in spent fuel pool. The test weight fell, and its upper end came to rest against a PWR fuel bundle. No apparent material damage was noted. $(80)$

- After loading a spent PWR fuel bundle into a shipping cask and while trying to disengage the loading tool (it would not release), the top nozzle was broken off the fuel bundle. Fuel rods were not damaged.(81)

- Top nozzles on PWR fuel bundles became separated (tack welds failed) from the perforated stainless steel can during cask loading operations with spent fuel (see entry in "Refueling..." above). (51)

- The top nozzle of a PWR fuel assembly broke off while the assembly was being lifted out of a storage rack in the spent fuel pool. (82) The 
assembly was almost out of the rack when the top nozzle broke off. The assembly did not fall but tipped $\sim 20^{\circ}$ from vertical. No radionuclides were released, and no fuel damage occurred.

- Damage to one PWR fuel bundle was caused by handling at the spent fuel pool. (83)

\section{Transporting Irradiated Fue l(a)}

- A truck with two casks containing irradiated fuel went over an embankment, but fuel remained safely in casks. No statement was made as to condition of fuel. 184 )

- A truck carrying 25 irradiated fuel elements in 7 casks collided with another vehicle. Fuel elements were undisturbed. ( 85$)$

- During truck shipment of irradiated fuel, trailer with cask became unhitched from tractor. Trailer tilted; cask slid and broke through end of trajler. No damage to cask; no statement was made as to condition of fue $1 .(85)$

- Railroad cask car with irradiated fuel elements derailed. No damage to cask car; no containment damage or increase in radiation intensity at cask surface. No comment made as to condition of fuel.(85)

- Switch engine backed into railway flatcar loaded with cask containing irradiated fuel elements and jounced flatcar about $91 \mathrm{~m}(300 \mathrm{ft})$. Cask was not displaced; no radiation release detected; no comment made as to condition of fuel.( 85 )

- Railroad shipment of irradiated fuel rods involved in two incidents. No radiation release detected; no comment was made as to condition of fue $1 .(85)$

- As a result of improper practices, cask loaded with irradiated fuel elements very rapidly moved forward about $4.6 \mathrm{~m}(15 \mathrm{ft})$ on the trailer, damaging trailer and truck. At a state port of entry, the truck was found to be carrying too much weight on rear axle of the trailer. Rear retaining chains on cask had been relaxed, and the truck had been driven on downgrade and brakes applied suddenly in an attempt to cause cask to shift position enough to meet state's weight requirement. Radiation survey indicated no increase in radiation or evidence of contamination. There was no evidence of physical damage to cask; however, the trailer was declared unroadworthy. At destination, second trailer, onto which cask had been loaded, was found to be contaminated (small liquid leak noted by couriers). No comment was made as to condition of fue 1. (85)

(a) Accidents involved in some cases. 
- During truck shipment of cask loaded with irradiated fuel elements, the cask shifted inside the sealed, exclusive-use trailer in transit. Cask tie-down cables had been attached to wooden blocks nailed to trailer floor. At destination, it was found that wooden blocks had pulled loose and cask had shifted. Cask lid and trailer bed were contaminated. Source of contamination was apparently residual water in cask that splashed out while cask was shifting during transit. No comment was made as to condition of fuel.(85)

- Leakage of contaminated cooling water occurred during railroad shipment of cask loaded with irradiated fuel elements (included some failed fuel elements in aluminum cans). Cask and car were contaminated; no comment was made as to condition of fuel. (85)

- Shipping container leaked during truck shipment of cask with irradiated plutonium fuel elements. Trailer and street (one location only) were contaminated; no comment was made as to condition of fue 1. (86)

- Cask containing irradiated fuel samples became contaminated durjng rail shipment. No comment was made as to the condition of the fuel. (87)

- Truck with loaded spent fuel cask overturned. Cask assembly was thrown into ditch and traveled over $30.5 \mathrm{~m}(100 \mathrm{ft})$. No release of cask contents or increase in radiation occurred. The fuel element was found to be und amaged. (88)

- During a truck shipment, the trailer carrying the cask containing spent fuel underwent a structural failure (it buckled) and the cask moved forward about $0.46 \mathrm{~m}$ (18 in.). There was no radioactive release; no comment was made as to condition of fuel.( 89$)$

Handling Irradiated Fuel After Shipment

\section{Interim Spent Fuel Storage Facility}

- A domestic facility has handled 1196 fuel bundles without dropping any. In early operations, it was difficult grappling bundles if they were deep in the cask cavity. Grapples sometimes got caught in the spring clip on top of PWR fuel bundles. A cask tipping incident led to a delay of several days. $(90)$

\section{Reprocessing Plant}

- Four PWR fuel bundles with stainless steel-clad fuel rods were shipped dry from a foreign reactor to a foreign reprocessing plant. Bundles appeared intact prior to shipment; however, they were from a lot that had experienced fuel failures during reactor operation. Radiation release from 
bundles was contained within cask during shipment. When the fuel was transferred from cask to storage pool, the pool water had higher than usual activity; the purification system soon permitted normal pool operations. Release was probably due to damage to fuel bundles during shipping. $(\dot{91}, 92)$

- Foreign spent fuel bundles with burnups to $3370 \mathrm{GJ} / \mathrm{kgU}$ ( $39.0 \mathrm{MWd} / \mathrm{kgU}$ ) have been stored, disassembled (more than $80 \mathrm{Mg}$ have been disassembled), and reprocessed in foreign facilities. Very few fuel rods were broken during disassembly operations. (93)

- One fuel bundle at a foreign plant fell from a vertical to a horizontal position.

Hot Cell Facility

- One PWR fuel bundle (with known defective fuel rods) was shipped dry to a hot cell facility. The fuel rods had stainless steel cladding. During transit, individual rods apparently reached temperatures of approximately 533 to $561 \mathrm{~K}$ ( 260 to $288^{\circ} \mathrm{C}$ ). (95) Radionuclide release was contained within the cask during shipment. Airborne contamination release was detected during the underwater unloading of the bundle from the cask. (95) attempts were made to remove five known failed fuel rods from the bundle to eliminate release of radionuclides from the failed rods into the pool at the hot cell.(94) It was extremely difficult to remove the rods because of the significant diameter increases, which were presumably caused by cladding splits. Four rods were removed with difficulty; the fifth rod broke about $0.25 \mathrm{~m}$ (10 in.) from the top end. The remainder of the rod was pushed back into the bundle.

\section{REFERENCES FOR APPENDIX}

1. Florida Power Corp., Incident Report, Docket 50302-209, November 20, 1975.

2. LeBlanc, J. and J. Gibbons. 1973. "Maine Yankee Startup and Initial Operations." In Proceedings of American Power Conference 35:215-236.

3. Letter, Florida Power and Light Co. to AEC-Division of Reactor Licensing. "Fuel Assembly Dropped at Turkey Point-4." Docket 50251, April 20, 1973.

4. Licensee Event Report 77-07. Docket 50313, March 10, 1977.

5. Wan, M. Y. 1976. Dresden 1 Plutonium Recycle Program Report for the Period July 1, 1975 through December 31, 1975. GA-A14106, General Atomic Company, San Diego, California, p. 16.

6. Iowa Electric Light and Power Company. "Abnormal Occurrence No. A0 50-331/75-31A, Supplemental Report." Docket 50331-518, October 1975.

7. Licensee Event Report 78-034/03L-0. Docket 50010, December 8, 1978. 
8. U.S. Nuclear Regulatory Commission. 1981. "Milestone-1." In Licensed Operating Reactors, Status Summary Report, Data as of $05 / 31 / 81$, NUREG-0020, 5(6):M-4.

9. Commonwealth Edison. Dresden Station Unit 3 - Fuel Performance Report, End of Cycle 1, Special Report No. 35, Docket 50249-404, April 29, 1974.

10. Williamson, H. E., and D. C. Ditmore. May 1972. Experience with BWR Fuel Through September 1971. NED0-10505, pp. 23-25 and 33-34.

11. Fue 1 Densification Effects on General Electric Boiling Water Reactor Fuel. NEDM-10735, Supp 1. 6-8, August 1973.

12. Thompson, D. 1974. "Summary of Recent Abnomal Occurrences at PowerReactor Facilities." Nuclear Safety, May-June, p. 334.

13. Commonwealth Edison. 1973. Dresden Station Unit 2 - Special Report No. 34, "Fue? Performance Report, Cycles I-III." Docket 50237-420, November 13, 1973.

14. Letter, Dairyland Power Cooperative to Directorate of Licensing, U.S. NRC. "La Crosse Boiling Water Reactor Abnormal Occurrence No. 75-2." Docket 50409-240, June 26, 1975.

15. Letter, Dairyland Power Cooperative to Directorate of Licensing, U.S. NRC. "La Crosse Boiling Water Reactor Abnormal Occurrence No. 75-2." Docket 50409-236, June 13, 1975.

16. Letter, Dairyland Power Cooperative to U.S. NRC, Division of Regulatory Operations. "La Crosse Boiling Water Reactor Abnormal Occurrence No. 75-2." Docket 50409-230, June 4, 1975.

17. Letter, Dairyland Power Cooperative to Directorate of Licensing, U.S. NRC. "LACBWR Cycle 3 Fuel Performance and Refueling Plan for Cycle 4 (LAC-TR-026)." Docket 50409-276, September 23, 1975.

18. Letter, Commonwealth Edison to U.S. NRC. "A Previous Abnomal Occurrence Report." Docket 50254-642, September 8, 1975.

19. Letter, Commonwealth Edison to Director of Office of Nuclear Reactor Regulation, U.S. NRC. "Misoriented Fue? Bund le." Docket 50254-551, February 21, 1975.

20. Dairyland Power Cooperative. 1971. Inspection of LACBWR Fue 7 in November 1970. DPC-851-20, Docket 115-5-99, January 29, 1971.

21. International Atomic Energy Agency. 1973. "Experience from Operating and Fueling Nuclear Power Plants." Proceedings of symposium in Vienna, Austria, October 8-12, 1973. (T. Tirupatiaih, K.S.N. Murthy, and R. Rajaram. "Core Performance and Fuel-Handling Operations at Tarapur." Paper No. IAEA-SM-178/43, pp. 539-540.) 
22. Letter, The Millstone Point Co. to AEC-Directorate of Licensing. "Control Blade Inspection at Millstone Point-1." Docket 50245, January 30, 1973.

23. Pickman, D. 0., et a1. 1973. "SGHWR Fuel Element Performance." BNES Conference on Nuclear Fuel Performance, October 15-19, 1973, London, pp. 51.1-51.6.

24. Letter, Yankee Atomic Electric Co. to Distribution. "Yankee Rowe Operation Report for October 1972." Docket 50029-216, December 1, 1972.

25. Letter, Yankee Atomic Electric Co. to AEC-Division of Regulatory Operations. "Damage to Fuel Element at Yankee Rowe." Docket 50029, November 20, 1973.

26. Letter, AEC-Directorate of Licensing to Yankee Atomic Electric Co. "Limited Rearrangement of Fuel Assemblies in Yankee Rowe Core X." Docket 50029, March 14, 1973.

27. "Report on the Tipped Fuel Assembly Occurrence at Zion Unit 2." Docket 50304-262, August 19, 1974.

28. R0 Inquiry Report No. 050-304/73-01Q from AEC to Commonwealth Edison Company, Zion Unit 2. Docket 50304, December 5, 1973.

29. TWX, Consumers Power Co. to E. 0. Jordan, Region III, U.S. NRC. Docket 50255-241, March 27, 1974.

30. Letter, Baltimore Gas and Electric Company to U.S. NRC (OI\&E, Region I). "LER 78-11." Docket 50317, March 1, 1978.

31. Letter, B. D. Withers (Portland General Electric) to R. A. Clark (NRC), "Preliminary Report on Trojan EOC-3 Fuel Examination," Docket No. 50344, June 25, 1981.

32. Bobe, P. E. January 1976. Fuel Performance of Licensed Nuclear Power Plants Through 1974. NUREG-0032, U.S. Nuc lear Regulatory Commission, Washington D.C.

33. Maine Yankee Atomic Power Company. 1972. Maine Yankee Operation Report for September 1972. Docket 50309-79, November 7, 1972.

34. Maine Yankee Atomic Power Company. 1974. Maine Yankee Semiannual Operating Report for the Period January 1, 1974, to June 30, 1974. Docket 50309, August 27, 1974.

35. 1974. "Maine Yankee Will Start up Again This Week." Nucleonics Week 15(37):8. (A McGraw-Hill publication.)

36. Letter, Maine Yankee Atomic Power Company to Directorate of Licensing, U.S. NRC. Docket 50309-262, October 15, 1974. 
37. 1974. "The Entire Maine Yankee Core Will Be Replaced Because of Fuel Densification." Nucleonics Week 15(50):4. (A McGraw-Hill publication.)

38. Electric Power Research Insitute. 1976. Evaluation of Fuel Performance in Maine Yankee Core 1, Task C. NP-218, Palo ATto, California.

39. Carolina Power and Light Co. 1973. H. B. Robinson, Unit 2 - Report Re the Discovery of Several Sections of a Fuel Assembly Grid Clip in Steam Generator C. Docket 50261-294, December 27, 1973.

40. Carolina Power and Light Co. 1974. H. B. Robinson, Unit 2 - Routine Operating Report No. 8 for Period January 1, 1974 - June 30, 1974. Docket 50261, August 29, 1974.

41. Licensee Event Report 79-044/03L-1. Docket 50272, July 30, 1979.

42. Memorandum, N. C. Mosely to B. H. Grier et al. "IE Circular No. 80-13, Grid Strap Damage in Westinghouse Fuel Assemblies." May 23, 1980.

43. Portland General Electric Co. to R. A. Clark, Directorate of Licensing, U.S. NRC. "Preliminary Report on Trojan EOC-2 Fuel Examination." Docket 50344, July 9, 1980.

44. Letter, J. D. O'Toole (Consolidated Edison Company of New York) to B. H. Grier (NRC), "Indian Point Unit No. 2, Docket No. 50247, LER-81-002/99x-2," May 19, 1981.

45. Skaritka, J., and J. A. Iorii. 1981. Operational Experience with Westinghouse Cores (up to December 31, 1980). WCAP-8183, Rev. 10. (pp.3-9 and 3-10; Point Beach-1, Cook-1, Zion-1, and Trojan-1).

46. See Reference 45, p. 3-10; Indian Point-2, Cook-2, Farley-1, and Ko-Ri.

47. Letter, Arkansas Power and Light Company to U.S. NRC, Region IV, Docket No. 50313, July 14, 1976. (Arkansas Nuclear One, Unit 1).

48. Letter, D. C. Trimble (Arkansas Power and Light Company) to R. A. Clark (NRC), "Arkansas Nuclear One-Unit 2, Docket No. 50368, License No. NPF-6, NRC Request for Information on Fuel Assembly Spacer Grid Damage," June 4, 1981 .

49. See Reference 45, pp. 3-10 and 3-11; Salem-1.

50. Letter, R. H. Graves, Connecticut Yankee Atomic Power Company, to U.S. NRC Region 3, Office of Inspection and Enforcement. "Informational Report, Core 9 Fuel Inspection." Docket 50213, July 16, 1980.

51. Pezzello, J. A., and M. Lee. June 1973. "Fuel Performance of Indian Point Unit No. 1." Trans. Am. Nuclear Soc. 16:102-103. 
52. Letter, Virginia Electric and Power Company to Office of Inspection and Enforcement. Docket 50281-335, June 3, 1975.

53. Letter, Virginia Electric and Power Company to Division of Reactor Licensing, U.S. NRC. Docket 50280-419, Ju1y 16, 1975.

54. Letter, R. L. Haueter, Consumers Power Company, Palisades Plant, to AEC-Directorate of Licensing. Docket 50255, December 16, 1971.

55. Licensee Event Report 78-018/99X-0. Docket 50309, August 29, 1978.

56. See Reference 45, p. 4-3; Prairie Island-2.

57. See Reference 45, p. 4-3; Beznau-1.

58. See Reference 45, p. 4-3; Indian Point-2.

59. See Reference 45, p. 4-4; Zion-1.

60. See Reference 45, p. 4-4; Prairie Island-2.

61. See Reference 45, p. 4-4; Indian Point-2.

62. Yankee Atomic Electric Co. 1969. Yankee Operation Report No. 104 for August 1969. Docket 50029, September 23, 1969.

63. Patrakka, E., and E. Tirri. 1981. "Fuel Examination Experience at Finnish Nuclear Power Plants." Presented at Specialist's Meeting on Examination of Fuel Assembly for Water-Cooled Power Reactors, IWGFPT/12, pp. 52-59, November 9-13, 1981, Tokyo, Japan.

64. Pryor, W. A. 1975. "IAEA Symposium on Experience and Fueling of Nuclear Power Plants." Nuclear Safety January-February, p. 83.

65. Robertson, R. I., and I. H. Gibson. 1973. "Production and Performance of Plutonium-Enriched Thermal Reactor Fue 1." Presented at BNES Conference on Nuclear Fuel Performance, October 15-19, 1973, London, pp. 53.1-53.4.

66. Williamson, H. E., and D. C. Ditmore. 1971. "Current BWR Fuel Design and Experience." Reactor Technology 14(1):68-98.

67. Bain, A. S., J. C. Wood, and C. E. Coleman. 1973. "Fuel Designs to Eliminate Defects on Power Increases." BNES Conference on Nuclear Fue 1 Performance, October 15-19, 1973, London, pp. 56.1-56.5.

68. Robertson, J.A.L., R. D. Page, and L. L. Bodie. 1973. Canadian Fuel Performance. AECL-4520, presented at the ANS Annual Meeting, Chicago, Illinois.

69. Robertson, J.A.L., and R. D. Page. 1973. "Canadian Fue 1 Performance." Trans. Am. Nuc 1. Soc. 16:102. 
70. Robertson, J.A.L. 1975. "Fuel Defect Mechanisms." In Proceedings of Joint Topical Meeting on Commercial Nuclear Fuel Technology Today. CNS ISSN 0068-8517, 75-CNA/ANS-100, Toronto, Ontario, Canada.

71. Letter, Consumers Power Company to AEC-Directorate of Licensing. "Spent Fuel Rod Found on Pool Floor." Docket 50155-181, November 20, 1973.

72. Letter, Consumers Power Company to J. F. O'Leary, AEC-Directorate of Licensing. Docket 50155-247, May 9, 1974.

73. Vesterlund, G. and T. 01sson. 1978. Degraderingsmeckanismer Vid Bassanglagering och Hantering av Utbrant Kraftreaktorbransle. RB 78-29, ASEA-ATOM, Vasteras, Sweden. (English translation, "Degradation Mechanisms During Pool Storage and Handing of Spent Power Reactor Fuel." BNWL-TR-320, Pacif ic Northwest Laboratory, Richland, Washington.)

74. Letter, G. D. Baston, Boston Edison Company, Pilgrim Nuclear Power Station, to AEC-Directorate of Licensing. "Transmitting Abnormal Occurrence Report AO 74/3." Docket 50293, January 30, 1974.

75. Letter, Pacific Gas and Electric Co. to U.S. NRC. Docket 50133-326, June 11, 1975.

76. Letter, Pacific Gas and Electric Co. to Office of Inspection and Enforcement, Region V, U.S. NRC. "Humboldt Bay Power Plant Unit No. 3." Docket 50133-264, June 11, 1975.

77. Carolina Power and Light Co., Brunswick Steam Electric Plant, Unit 2. 1976. Information Report on Fuel Bundle Falling out of Fuel Preparation Machine. Docket 50324, Apri1 16, 1976.

78. Letter, W. G. Counsil, Millstone Point Company, Millstone Nuclear Power Station, to AEC-Directorate of Licensing. "Transmitting Abnormal Occurrence Report A0 74/5." Docket 50245-421, September 25, 1974.

79. Letter, Florida Power and Light Co. to Office of Nuclear Reactor Regulation, U.S. NRC. Docket 50251-352, May 6, 1975.

80. Licensee Event Report 78-031/0IT-0. Docket 50302, June 21, 1978.

81. Letter (TWX), Consolidated Edison Co. of New York, to AEC-Directorate of Licensing. "Failure of Fuel Assembly Nozzle." Docket 50003, August 27, 1970 .

82. Letter, L. 0. Mayer (Northern States Power) to Region III (U.S. NRC), "Spent Fuel Assembly D-34 Top Nozzle Event (License Event Report No. 81-031/01T-0)," Docket 50282, December 30, 1981.

83. Consumers Power Company. 1974. Palisades Plant Semiannual Report of Operations No. 7 for Period January 1, 1974 Through June 30, 1974. Docket 50255, August 30, 1974. 
84. A Summary of Transportation Incidents in Atomic Energy Activities, 1949-1956. AECU-3613, December 1957, p. 25.

85. Patterson, D. E., and V. P. DeFatta. November 1962. A Summary of Incidents Involving USAEC Shipments of Radioactive MateriaT, 1957-1961. TID-16764, pp. 7, 17, 22, 25, 29, 51, 53, and 67.

86. Patterson, D. E., and A. Mehn. November 1963. A Summary of Incidents Involving USAEC Shipments of Radioactive Material, 1962. TID-16764, Supp Tement 1, p. 28.

87. A Summary of Incidents Involving USAEC Shipments of Radioactive Material, 1963-1964. TID-16764, Supplement 2, undated, p. 9.

88. Grella, A. W. A Review of Five Years (1971-1975) Accident Experience in the USA Involving Nuclear Transportation. IAEA-SR-10/5, International Atomic Energy Agency, Vienna, Austria.

89. Letter, C. Reed, Commonwealth Edison, to J. G. Keppler, I E, Region III, U.S. NRC. Docket 50010, February 28, 1978.

90. Eger, K. J., and G. E. Zima. 1979. Commentary on Spent Fuel Storage at Morr is Operations. NUREG/CR-0956, PNL-3065, Pacific Northwest Laboratory, Richland, Washington.

91. Johnson, A. B., Jr., et al. May 1980. Annual Report-FY1979, Spent Fuel and Fuel Pool Component Integrity. PNL-3171, Pacific Northwest Laboratory, Richland, Washington.

92. Johnson, A. B., Jr. 1979. "Spent Fuel Storage Experience." Nucl. Tech. 43:163-172.

93. Huppert, K. L. 1978. "Spent Fuel Storage - Philosophies and Experience." In Proceedings of NEA Seminar on Storage of Spent Fuel Element, Madrid, Sp ain, June 20-23, 1978, pp. 19-29.

94. Letter, W. G. Counsil (Connecticut Yankee Atomic Power Company) to D. M. Crutchfield (U.S. NRC), "Haddam Neck Plant-Interim Report on Fuel Rod Failures" Docket No. 50213, January 19, 1981. (The attached report, BCL-585-19, is dated November 1980 and was prepared by Battelle Columbus Laboratories in Col umbus, Ohio).

95. Klingensmith, R. W. November 1980. "Airborne Contamination Released During Underwater Unloading of a Spent Fuel Assembly." Sixth International Symposium Packaging and Transportation of Radioactive Materials (PATRAM 80 ), West Berlin, FRG. 